\title{
Distribution and Condition of Larval and Juvenile Lost River and Shortnose Suckers in the Williamson River Delta Restoration Project and Upper Klamath Lake, Oregon: 2009 Annual Data Summary
}

Open-File Report 2010-1216 



\section{Distribution and Condition of Larval and Juvenile Lost River and Shortnose Suckers in the Williamson River Delta Restoration Project and Upper Klamath Lake, Oregon: 2009 Annual Data Summary}

By Summer M. Burdick and Daniel T. Brown

Open-File Report 2010-1216

U.S. Department of the Interior

U.S. Geological Survey 


\section{U.S. Department of the Interior \\ KEN SALAZAR, Secretary}

\section{U.S. Geological Survey \\ Marcia K. McNutt, Director}

U.S. Geological Survey, Reston, Virginia: 2010

For more information on the USGS-the Federal source for science about the Earth, its natural and living resources, natural hazards, and the environment, visit http://www.usgs.gov or call 1-888-ASK-USGS.

For an overview of USGS information products, including maps, imagery, and publications, visit http://www.usgs.gov/pubprod

To order this and other USGS information products, visit $h$ ttp://store.usgs.gov

Suggested citation:

Burdick, S.M., and Brown, D.T., 2010, Distribution and condition of larval and juvenile Lost River and shortnose suckers in the Williamson River Delta restoration project and Upper Klamath Lake, Oregon: 2009 annual data summary: U.S. Geological Survey Open-File Report 2010-1216, 78 p.

Any use of trade, product, or firm names is for descriptive purposes only and does not imply endorsement by the U.S. Government.

Although this report is in the public domain, permission must be secured from the individual copyright owners to reproduce any copyrighted material contained within this report. 


\section{Contents}

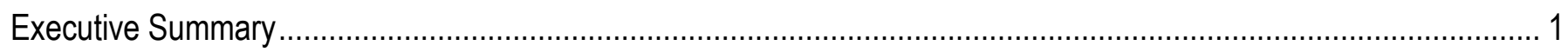

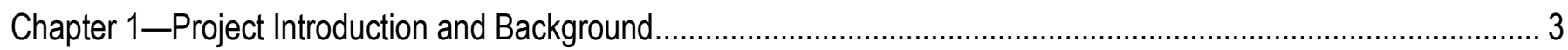

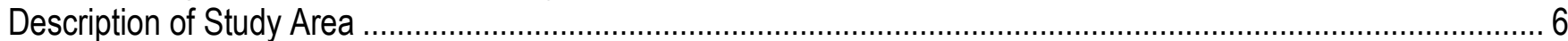

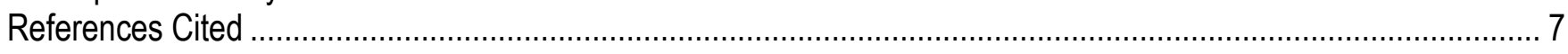

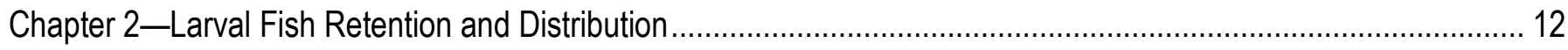

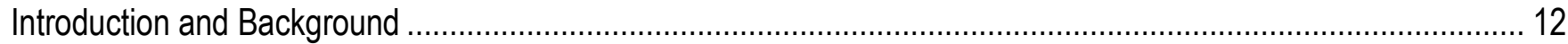

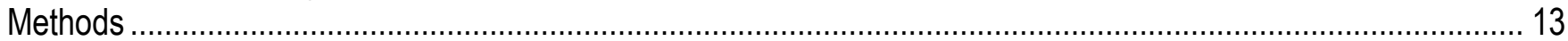

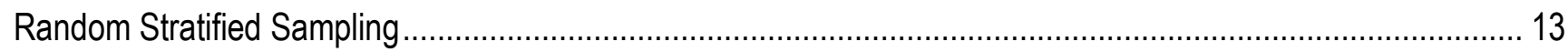

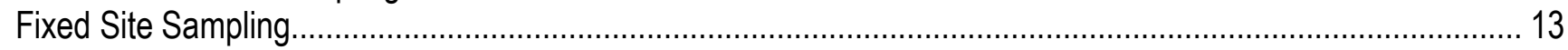

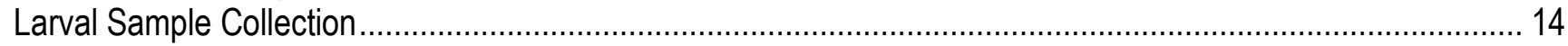

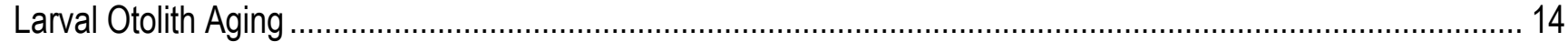

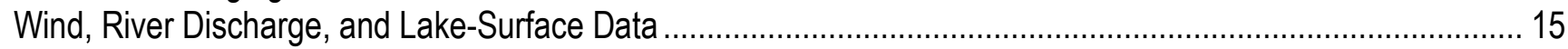

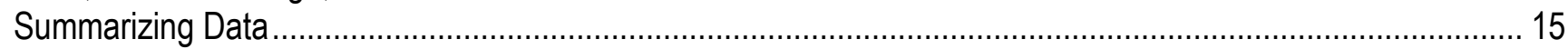

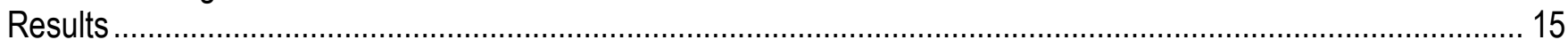

Spatial Patterns in Relative Abundance, Condition, and Age of Larval Suckers.............................................. 15

Larval Sucker Distribution, Condition, and Sample Density along Predicted Hydrodynamic Pathways................ 16

Spatial and Temporal Patterns in the Larval Fish Community ..................................................................... 18

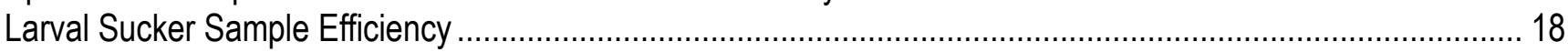

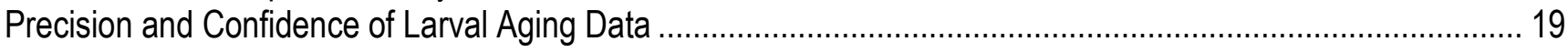

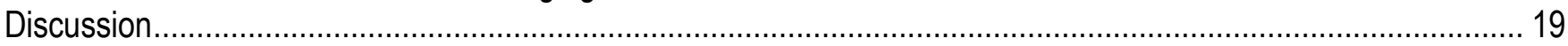

Larval Sucker Habitat Use, Relative Abundance, and Condition in the Williamson River Delta and Adjacent

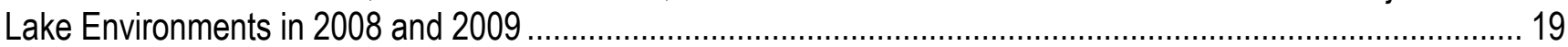

Larval Sucker Distribution, Transport, and Residence Time Relative to Hydrodynamic Conditions ....................... 20

Larval Fish Community Characterization ............................................................................................... 21

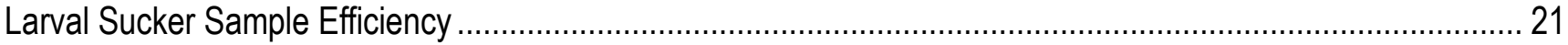

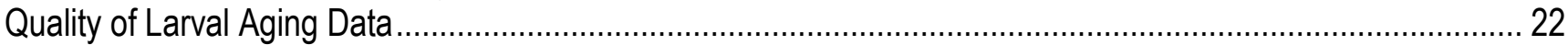

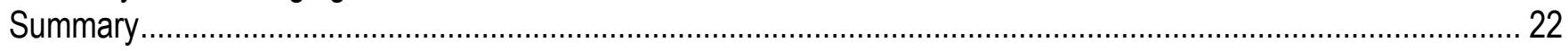

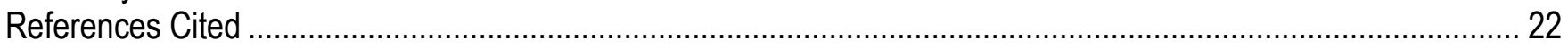




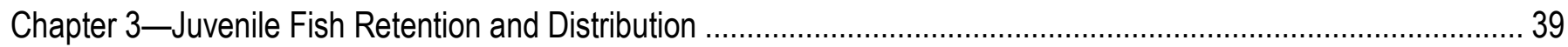

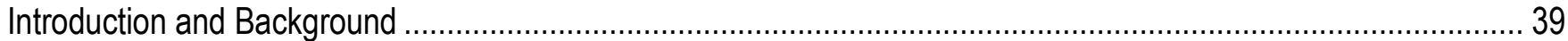

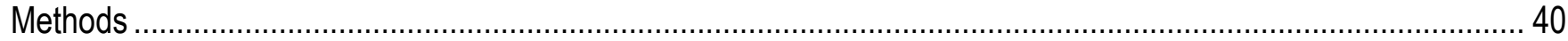

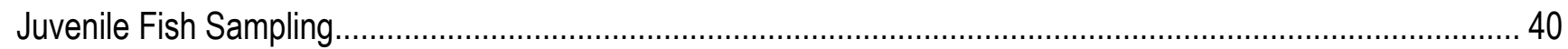

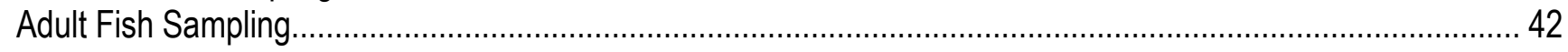

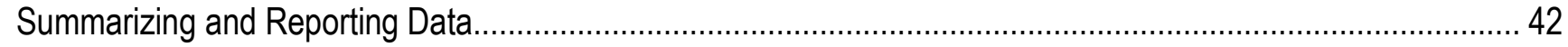

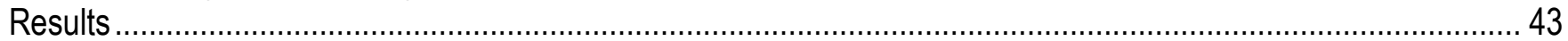

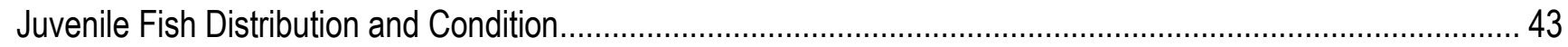

Fish Community and Distribution of Piscivorous Fishes ........................................................................... 47

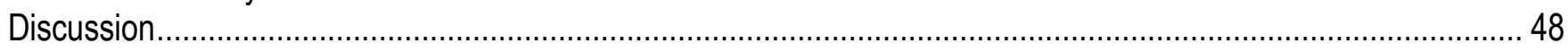

Comparison of Juvenile Sucker Catch Rates among Years and Water-bodies ................................................. 48

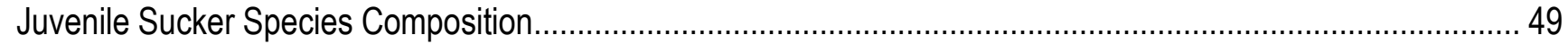

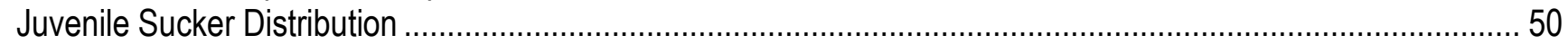

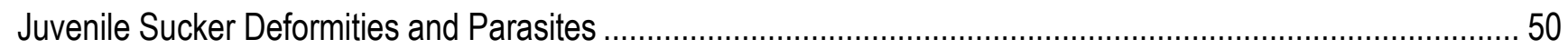

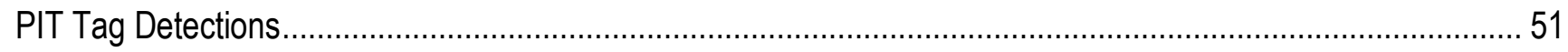

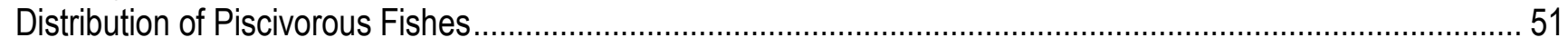

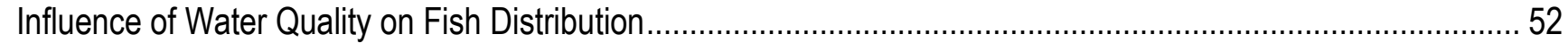

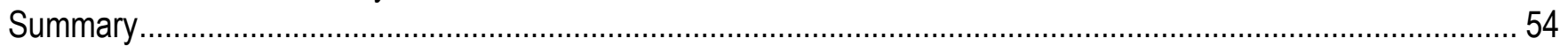

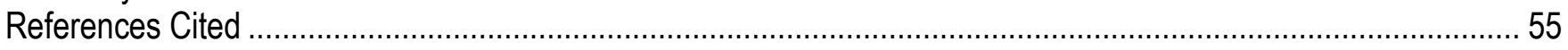

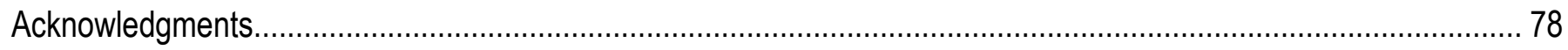




\section{Conversion Factors}

\begin{tabular}{|c|c|c|}
\hline Multiply & By & To obtain \\
\hline \multicolumn{3}{|c|}{ Length } \\
\hline centimeter $(\mathrm{cm})$ & 0.3937 & inch (in) \\
\hline millimeter (mm) & 0.03937 & inch (in) \\
\hline meter $(\mathrm{m})$ & 3.281 & feet $(\mathrm{ft})$ \\
\hline kilometer (km) & 0.6214 & mile (mi) \\
\hline micron $(\mu \mathrm{m})$ & $3.9 \times 10^{-5}$ & inch (in.) \\
\hline \multicolumn{3}{|c|}{ Area } \\
\hline square kilometer $\left(\mathrm{km}^{2}\right)$ & 247.15 & acre \\
\hline square meter $\left(\mathrm{m}^{2}\right)$ & 10.76 & square foot $\left(\mathrm{ft}^{2}\right)$ \\
\hline \multicolumn{3}{|c|}{ Speed } \\
\hline meters per second $(\mathrm{m} / \mathrm{s})$ & 2.23 & miles per hour (mph) \\
\hline meters per second $(\mathrm{m} / \mathrm{s})$ & 3.28 & feet per second (fps) \\
\hline \multicolumn{3}{|c|}{ Volume } \\
\hline cubic meters $\left(\mathrm{m}^{3}\right)$ & 35.314 & cubic feet $\left(\mathrm{ft}^{3}\right)$ \\
\hline microliter $(\mu \mathrm{L})$ & $6.1 \times 10^{-5}$ & cubic inch $\left(\mathrm{in}^{3}\right)$ \\
\hline liter $(\mathrm{L})$ & 0.2642 & gallon (gal) \\
\hline \multicolumn{3}{|c|}{ Volumetric Rate } \\
\hline cubic meters per second $\left(\mathrm{m}^{3} / \mathrm{s}\right)$ & 35.314 & cubic feet per second $\left(\mathrm{ft}^{3} / \mathrm{s}\right)$ \\
\hline \multicolumn{3}{|c|}{ Concentration } \\
\hline millimole (mM) & $6.022 \times 10^{-20}$ & molecules or atoms \\
\hline nanograms per microliter $(\mathrm{ng} / \mathrm{mL})$ & 0.1335 & ounce per gallon (oz/gal) \\
\hline milligrams per milliliter (mg/mL) & $1.335 \times 10^{-4}$ & ounce per gallon (oz/gal) \\
\hline milligrams per liter $(\mathrm{mg} / \mathrm{L})$ & $1.335 \times 10^{-6}$ & ounce per gallon (oz/gal) \\
\hline \multicolumn{3}{|c|}{ Frequency } \\
\hline kilohertz (kHz) & $1.66 \times 10^{-5}$ & rounds per minute (rpm) \\
\hline \multicolumn{3}{|c|}{ Potential Energy } \\
\hline kilovolts (kV) & 0.001 & watt per ampere (W/A) \\
\hline \multicolumn{3}{|c|}{ Mass } \\
\hline gram $(\mathrm{g})$ & 0.03527 & ounce, avoirdupois (oz) \\
\hline kilogram (kg) & 2.205 & pound, avoirdupois (lb) \\
\hline
\end{tabular}

Temperature in degrees Celsius $\left({ }^{\circ} \mathrm{C}\right)$ may be converted to degrees Fahrenheit $\left({ }^{\circ} \mathrm{F}\right)$ as follows:

${ }^{\circ} \mathrm{F}=\left(1.8 \times{ }^{\circ} \mathrm{C}\right)+32$.

Concentrations of chemical constituents in water are given either in milligrams per liter (mg/L) or micrograms per liter $(\mu \mathrm{g} / \mathrm{L})$. 


\section{Datum}

Vertical coordinate information is referenced to the Western Geographic System of 1984 (WGS84).

\section{Abbreviations and Acronyms}

\begin{tabular}{ll}
\hline \multicolumn{1}{c}{ Abbreviations } & \multicolumn{1}{c}{ Meaning } \\
\hline CPUE & catch per unit effort \\
DO & dissolved oxygen \\
NL & notochord length \\
OSU & Oregon State University \\
PIT & passive integrated transponder \\
SD & standard deviation of the mean \\
SNS-KLS & shortnose or Klamath largescale sucker \\
TNC & The Nature Conservancy \\
USBR & U.S. Bureau of Reclamation \\
USGS & U.S. Geological Survey \\
\hline
\end{tabular}




\title{
Distribution and Condition of Larval and Juvenile Lost River and Shortnose Suckers in the Williamson River Delta Restoration Project and Upper Klamath Lake, Oregon: 2009 Annual Data Summary
}

\author{
By Summer M. Burdick and Daniel T. Brown
}

\section{Executive Summary}

Federally endangered Lost River sucker (Deltistes luxatus) and shortnose sucker (Chasmistes brevirostris) were once abundant throughout their range but populations have declined. They were extirpated from several lakes in the 1920s and may no longer reproduce in others. Poor recruitment to the adult spawning populations is one of several reasons cited for the decline and lack of recovery of these species and may be the consequence of high mortality during juvenile life stages. High larval and juvenile sucker mortality may be exacerbated by an insufficient quantity of suitable or high quality rearing habitat. In addition, larval suckers may be swept downstream from suitable rearing areas in Upper Klamath Lake into Keno Reservoir, which is seasonally anoxic.

The Nature Conservancy flooded about 3,600 acres (1,456 hectares) to the north of the Williamson River mouth (Tulana Unit) in October 2007 and about 1,400 acres (567 hectares) to the south and east of the Williamson River mouth (Goose Bay Unit) a year later to retain larval suckers in Upper Klamath Lake, create nursery habitat, and improve water quality. The U.S. Geological Survey joined a long-term research and monitoring program in collaboration with The Nature Conservancy, the Bureau of Reclamation, and Oregon State University in 2008 to assess the effects of the Williamson River Delta restoration on the early life-history stages of Lost River and shortnose suckers. The primary objectives of the research were to describe habitat colonization and use by larval and juvenile suckers and non-sucker fishes and to evaluate the effects of the restored habitat on the health and condition of juvenile suckers. This report summarizes data collected in 2009 by the U.S. Geological Survey as a part of this monitoring effort.

The Williamson River Delta appeared to provide suitable rearing habitat for endangered larval Lost River and shortnose suckers in 2008 and 2009. Larval suckers captured in this delta typically were larger than those captured in the adjacent lake habitat in 2008, but the opposite was true for larval shortnose suckers in 2009. Mean sample density was greater for both species in the Williamson River Delta than adjacent lake habitats in both years. Larval suckers captured in the restoration area, however, had less food in their guts compared to those captured in Upper Klamath or Agency Lakes.

Differential distribution among sucker species within the Williamson River Delta and between the delta and adjacent lakes indicated that shortnose suckers likely benefited more from the restored Williamson River Delta than Lost River or Klamath largescale suckers (Catostomus snyderi). Catch rates in shallowwater habitats with vegetation within the delta were higher for shortnose and Klamath largescale suckers than for larval Lost River suckers in 2008 and 2009.However, catch rates at the mouth of the Williamson River in 2008 and in Upper Klamath Lake in 2009 were higher for larval Lost River suckers than for larvae identified as either shortnose or Klamath largescale suckers. Shortnose suckers also comprised the greatest portion of age-0 suckers captured in the Williamson River Delta in 2008 and 2009. The relative abundance 
of age-1 shortnose suckers was high in our catches compared to age-1 Lost River suckers in 2009 in the delta and adjacent lakes, which may or may not indicate shortnose suckers experienced better survival than Lost River suckers in 2008.

Age- 0 and age- 1 suckers were similarly distributed throughout the Williamson River Delta in 2008 and 2009. Age-0 suckers used shallow vegetated and unvegetated habitats primarily in mid- to late July in both years. A comparison of catch rates between our study and a concurrent study in Upper Klamath Lake indicated that Goose Bay was the most used habitat in 2009 and the Tulana Unit was the one of the least used habitats in 2008 and 2009 by age- 0 suckers. Catch rates for age- 1 suckers, however, indicated that both of these areas were heavily used by age-1 suckers in May 2009. Age-1 sucker catches shifted from the shallow water (about 0.5-1.5 meters deep) eastern side of the Williamson River Delta in May, to mid-depth (about 1.5-2.7 meters deep) environments in June, and then to deep (about 4-6 m deep) open water areas within the delta, Agency Lake, and Upper Klamath Lake at the end of June and early July in both years.

A pilot project conducted in 2009 demonstrated the potential for passive integrated transponder tags to be used to study mortality and movement of age-1 and age- 2 suckers in Upper Klamath Lake and the Williamson River Delta. We injected 132 age-1 and age-2 suckers with passive integrated transponder tags, between mid-April and late June. Eight percent of these tags were detected on remote underwater antennas arrays and at piscivorous bird colonies. Although higher detection rates are desirable for estimating mortality rates, movement and sources of mortality could be inferred if more tags were used and we achieved a similar detection rate.

A concurrent study by The Nature Conservancy indicated that periods of high $\mathrm{pH}$, low dissolvedoxygen concentrations, and relatively high un-ionized ammonia concentrations occurred in our study area in 2008 and 2009, and were associated with blooms of cyanobacteria. Conditions were more severe and lasted longer in 2008 than in 2009 in the study area. Levels of pH and high water temperatures exceeded published tolerance limits for juvenile suckers in parts of the delta but apparently did not influence distribution. High concentrations of un-ionized ammonia and low concentrations of dissolved-oxygen were associated with low numbers of juvenile suckers in our catches.

Only two piscivorous fishes that appeared to pose a meaningful threat of predation to suckers were captured in 2009-fathead minnows (Pimephales promelas) and yellow perch (Perca flavescens). Fathead minnows that prey on larval but not juvenile suckers dominated catches in all strata, but made up a small portion of fish caught in the shallow-water Goose Bay stratum in 2009 and Tulana Emergent stratum in 2008 and 2009, where larval shortnose suckers primarily were captured. Two cohorts of yellow perch were detected in our samples. Based on their gape size and patterns of co-occurrence, the smaller cohort was capable of preying on larval suckers and the larger cohort was capable of preying on age-0 juvenile suckers. Larval yellow perch were captured throughout our study area in 2009 but not in 2008. This could indicate that yellow perch only spawned in the delta and adjacent lake habitat during the second year of our study.

The first two years of this study indicated the Williamson River Delta restoration project successfully created suitable rearing habitat for larval and juvenile suckers. However, it is unknown weather restoration will ultimately increase the number of adults. Because the estimated age of initial spawning is between 6 and 14 years, we do not expect to see population level effects of the Williamson River Delta restoration for some time. Until then, it will be important to continue to monitor the use of the delta by larval and juvenile suckers. Because juvenile suckers do not spend all their time in the Williamson River Delta, it also is important to determine the causes of juvenile sucker mortality to understand poor juvenile to adult survival. 


\section{Chapter 1-Project Introduction and Background}

Federally endangered Lost River sucker (Deltistes luxatus) and shortnose sucker (Chasmistes brevirostris) are long-lived, late-maturing fishes endemic to the Upper Klamath Basin of northern California and southern Oregon. These species are obligate lake dwellers that spawn in rivers or at shoreline springs. Although once abundant throughout their range, these suckers were extirpated from several lakes including Lower Klamath Lake, Sheepy Lake, and Lake of the Woods (National Research Council, 2004). It also is suspected that other populations, such as those in Tule Lake and Keno Reservoir, no longer reproduce (National Research Council, 2004). One of the most important remaining habitats for these suckers is Upper Klamath Lake and its tributaries, where successful spawning is known to occur (National Research Council, 2004).

The Upper Klamath Lake populations of Lost River and shortnose suckers migrate to springs located along the east shore of Upper Klamath Lake, the lower Williamson River, or the Sprague River to spawn between March and May (Ellsworth and others, 2007). Eggs are spread over gravel and cobble substrates (Andreasen, 1975). Between mid-April and the end of May, larvae spawned in the river systems, emerge from gravel and drift downstream (Ellsworth and others, 2009). Larvae begin to reach the Williamson River Delta by Late April (Crandall, 2004). By June, most young-of-the-year suckers have developed fin rays and other morphological characteristics of adults, at which point they are considered juveniles (Kelso and Rutherford, 1996; Ellsworth and others, 2009). Between June and September, age-0 juvenile suckers disperse throughout Upper Klamath Lake and its' littoral marshes (Burdick and others, 2009a). The period spanning their first September and their first spawning migration, which occurs between 6 and 14 years of age (Buettner and Scoppetone, 1990), however, has yet to be adequately described (Burdick and others, 2009a).

Poor juvenile to adult recruitment is one of several reasons cited for the decline and lack of recovery of Lost River and shortnose suckers (National Research Council, 2004). Sharp decreases in age-0 sucker catch rates during early fall and extremely low catches of age-1 or older sub-adult suckers (Simon and Markle, 2002; Hendrixson and others, 2007; Burdick and others, 2009a) may indicate high juvenile mortality. Sub-optimal rearing habitat may be associated with reduced juvenile growth or development or increased rates of predation by birds or piscivorous fish.

Wind driven water currents in Upper Klamath Lake typically flow in a clockwise direction (Wood and others, 2008) and may push larvae originating from the Williamson River south along the eastern shore to the outlet of the lake and into Keno Reservoir (Markle and others, 2009). Markle and others (2009) estimate that it takes an average of 5 days for Lost River suckers and 10 days for shortnose suckers to be transported from the mouth of the Williamson River out of Upper Klamath Lake and into the Keno Reservoir. Dissolved-oxygen (DO) concentrations that routinely approach zero nearly every summer in the Keno Reservoir (Sullivan and others, 2009), located downstream of Upper Klamath Lake, are a direct cause of larval and juvenile sucker mortality within that reservoir. One way to slow the transport of larvae from the lake is to create well-vegetated marshes that intercept fish and remove them from the main current (Markle and others, 2009).

Marshes also provide important habitat for older juvenile suckers for at least part of the year. Age-0 juveniles use a variety of habitats throughout Upper Klamath Lake, including stands of emergent vegetation in and around the Williamson River Delta (Burdick and others, 2009a). Age-1 suckers are concentrated along the edges of patches of vegetation in tributary mouths and near springs during April and May (Markle and Simon, 1993). This age class primarily is found in open water habitats between 4 and $5 \mathrm{~m}$ deep during June and July (Burdick and others, 2009a). 
The Williamson River Delta probably was one of the most important wetlands for larval and juvenile suckers, due to its location downstream of known productive spawning grounds in the Williamson and Sprague rivers (fig. 1.1). Prior to river channelization and wetland draining in beginning in 1940, larval suckers probably were retained in emergent vegetation along the shorelines of the Williamson River (National Research Council, 2004). Historically, juvenile suckers may have reared for several months to several years in the emergent or submerged vegetation and deep water wetlands along marsh edges or in the marsh interior (National Research Council, 2004). More recently, larval suckers have been documented in Riverbend Marsh and in the Tulana Unit of the Williamson River Delta near the mouth of the Williamson River beginning in mid-May (Hendrixson, 2008; The Nature Conservancy, 2010). Juvenile suckers also have been captured in Upper Klamath Lake near the Williamson River mouth as late as mid-September (Hendrixson and others, 2007).

To retain create nursery habitat for suckers, and improve water quality in Upper Klamath Lake, The Nature Conservancy (TNC) flooded about 3,600 acres to the north of the Williamson River mouth (Tulana Unit) in October 2007 and about 2,000 acres to the east of the Williamson River (Goose Bay Unit) in October 2008 (fig. 1.2; The Nature Conservancy, 2009). Explosives and mechanical methods were used to breach large sections of dikes separating the delta from the Williamson River, Upper Klamath Lake, and Agency Lake. We refer to the resulting gaps in the dikes as breaches. Based on knowledge of maximum water depths and duration of flood tolerances of vegetation communities, five types of aquatic and riparian environments were predicted (table 1.1), four of which could potentially provide habitat for larval and juvenile suckers. One additional predicted vegetation community could potentially provide habitat for larval but probably not juvenile suckers: riparian or wet prairie (less than about $0.6 \mathrm{~m}$ deep; David Evans and Associates Inc., 2005). Hydrodynamic modeling of the restoration area was used to determine the location of levee breaches that would result in the maximum flow out of the Williamson River channel into both the Tulana and Goose Bay Units of the Delta, as well as the maximum flow through the Tulana and Goose Bay Units and into Upper Klamath Lake (Daraio and others, 2004). This also would ensure that the maximum number of larvae would be transported into the developing wetlands. A hydrodynamic model of Upper Klamath Lake that incorporated the Tulana Unit prior to flooding predicted that the restoration would increase the travel time of larvae between the upstream end of the Williamson River Delta and the outlet of the lake because many larvae would take a longer, more circuitous pathway through the Tulana Unit before entering Upper Klamath Lake (T. Wood, U.S. Geological Survey, written commun., 2007).

Development of a carefully planned monitoring program was essential to provide information for making adaptive management decisions as the marsh develops. Evaluation of the Williamson River Delta also is important to develop plans for future restoration. Given the primary goals of the Williamson River Delta restoration project, evaluating how and when early life stage suckers use the restored habitat, how fish assemblages change within the restored habitat as the marsh develops, and how the health and growth of suckers is affected by the restoration activities are important goals of monitoring.

A better understanding of larval and juvenile Lost River and shortnose sucker habitat use within the Williamson River Delta also could explain poor recruitment, provide more information on life history patterns of juvenile suckers, test the hypothesis that marsh rearing habitat is required for strong year class development, and connect physical lake processes to biological patterns. These data also provide additional information on the effects of lake level manipulation on juvenile suckers. Such information could aid endangered sucker management. 
In 2008, the USGS joined a long-term research and monitoring program to assess the effects of the Williamson River Delta restoration on the early life-history stages of Lost River and shortnose suckers. This project is a collaboration with TNC, Bureau of Reclamation, and Oregon State University (OSU). The goal of this collaboration is to evaluate the effects of Williamson River Delta restoration project on suckers in their first several years of life. Specifically, this partnership is interested in modeling the effect of hydrodynamics on larval retention in the restoration area and documenting changes in apparent survival of juvenile suckers in relation to the reestablishment of the delta.

Responsibilities for data collection and monitoring were divided among collaborators based on interests and areas of expertise. The Nature Conservancy continued long-term monitoring of the distribution, gut fullness, and relative abundance of sucker and non-sucker larvae in shallow $(<1 \mathrm{~m})$ environments on the eastern side of the Tulana Unit, in the Goose Bay Unit of Williamson River Delta, in two smaller, early action restoration wetlands on the Williamson River Delta (Riverbend and South Marsh), and along the shoreline immediately east of the mouth of the river. Researchers from OSU extended a longterm monitoring program of larval and juvenile sucker relative abundance in Upper Klamath Lake to include the new shoreline created by flooding the delta. The work of the USGS focused on documenting the use of deep water environments in the Goose Bay and Tulana units of the Williamson River Delta by larval and juvenile suckers.

Our objectives were:

- Objective 1: Describe geographic and temporal use of deep ( $>1 \mathrm{~m})$ and shallow water environments by larval and juvenile suckers within the newly restored Williamson River Delta.

- Objective 2: Compare the probability of habitat use by juvenile suckers among habitats in the Williamson River Delta restoration area and open water areas of Upper Klamath Lake.

- Objective 3: Compare fish community structure in the Williamson River Delta restoration area to open water areas of Upper Klamath Lake.

- Objective 4: Describe the temporal and spatial succession of non-sucker fishes and juvenile suckers as they colonize or recolonize in the Williamson River Delta.

- Objective 5: Compare the growth, condition, and health of juvenile suckers from the Williamson River Delta restoration area to those from Upper Klamath Lake.

For this long-term project, we committed to producing annual data summaries as well as comprehensive reports deliverable every 3 years. Annual data summaries, like this one, are peerreviewed open-file reports intended to make data available to our partners and other resource management agencies quickly. Comprehensive, peer-reviewed reports will contain analysis and interpretation of these data.

This data summary is organized into two chapters. The first chapter focuses on the distribution, condition, and transport of larval suckers and non-sucker larvae throughout the Williamson River Delta and adjacent aquatic environments. The second chapter is a detailed summary of juvenile sucker condition, juvenile sucker distribution in relation to environmental variables, and spatial patterns in fish communities. 


\section{Description of Study Area}

The study area is located in and adjacent to the Williamson River Delta at the terminus of the Williamson River, which flows approximately $85 \mathrm{~km}$ from headwaters in Klamath Marsh. The Williamson River Delta generally is defined as the area at the mouth of the Williamson River, spanning Agency and Upper Klamath lakes in south-central Oregon. It is divided into two units by the Williamson River; the Goose Bay Unit to the south and east of the Williamson River and the Tulana Unit to the west and north of the Williamson River (fig. 1.2). We sampled a 1-km band along the shoreline of the north end of Upper Klamath Lake, presently the largest lake in the Klamath River Basin, the southern one-third of Agency Lake, and in inundated portions of the Tulana Unit of the Williamson River Delta (figs. 1.2).

We divided our effort among six areas or sampling strata. Three strata were located in the Tulana Unit of the Williamson River Delta and were delineated based on expected eventual plant communities and depth measurements taken prior to sampling in 2009 (fig. 1.2; David Evans and Associates Inc., 2005). These include (1) the western portion of the Tulana restoration unit predicted to remain unvegetated (Tulana Open Water), (2) an area located in the center of the Tulana Unit predicted to establish submergent vegetation (Tulana Submergent), and (3) the eastern side of the Tulana Unit that was predicted to establish emergent vegetation (Tulana Emergent; fig. 1.2). The Tulana Submergent stratum in our report is referred to as deep water wetland by The Nature Conservancy. One stratum was located entirely in the Goose Bay Unit of the delta (Goose Bay). The other two strata were selected to provide a comparison with adjacent lake environments and were defined as (1) the southern one-third of Agency Lake (Agency Lake) and (2) a band of Upper Klamath Lake about $1 \mathrm{~km}$ wide located along the former southern and western shore of the Tulana and Goose Bay restoration units (Upper Klamath Lake; see chapter 1). The Upper Klamath Lake strata was sampled for larval fish in this study and for juvenile suckers in a concurrent study that included the entire Upper Klamath Lake (U.S. Geological Survey, unpub. data, 2009).

Within the Williamson River Delta there is variation in depth and vegetation. The substrate consists primarily of mud and clay with patches of sand mixed with gravel and cobble. Agency and Upper Klamath lakes are shallow (about 2-3 m) and mostly devoid of vegetation. Agency Straits, a narrow waterway connecting Agency and Upper Klamath lakes, was considered part of Agency Lake and had a maximum depth of $7.4 \mathrm{~m}$. The Goose Bay Unit is generally less than $1 \mathrm{~m}$ deep and 90 percent of the predicted emergent vegetation zone had no vegetation or was covered with decomposing agricultural remnants (i.e. barley) in 2009 (Elseroad and others, 2010). The Tulana Open Water stratum was the deepest of the area we sampled and least vegetated with occasional stands of willows (Salix spp.). In this area, there is a pocket of deep water $(4-6 \mathrm{~m})$ in the northwestern corner. Intermediate depths can be found in the Tulana Submergent area (about 1.5-2.75 m deep), which contained very little vegetation in the spring followed by scattered patches of water smartweed (Polygonum amphibium; Elseroad and others, 2009), and coontail (Ceratophyllum demersum) in mid- to late summer. The Tulana Emergent area was the shallowest area we sampled in the Tulana Unit $(<1 \mathrm{~m})$. This stratum contained dense patches of tule (Schoenopletcus acutus) mixed with broadleaf cattail (Typha latifolia), pondweed (Potamogeton spp.), and water smartweed interspersed between patches of open water.

The entire study area, including the delta and both lakes, experiences blooms of the cyanobacteria, Aphanizomenon flos-aquae, which are associated with DO concentrations that fluctuate from supersaturation to anoxia and $\mathrm{pH}$ frequently exceeds 9.0 (Lindenberg and others, 2008). High pH, low DO concentrations, and high un-ionized ammonia concentrations at levels potentially lethal to juvenile Lost River and shortnose suckers periodically occur every summer (Wood and others, 2006). 


\section{References Cited}

Andreasen, J.K., 1975, Systematics and status of the Family Catostomidae in southern Oregon: Corvallis, Oreg., Oregon State University, Ph.D. thesis, 80 p.

Buettner, M., and Scoppettone, M.M., 1990, Life history and status of Catostomids in Upper Klamath Lake, Oregon: Oregon Department of Fish and Wildlife, Klamath Tribe, and National Fisheries Research Center, Reno, Nevada.

Burdick, S.M., VanderKooi, S.P., and Anderson, G.O., 2009a, Spring and summer spatial distribution of endangered juvenile Lost River and shortnose suckers in relation to environmental variables in Upper Klamath Lake, Oregon-2007 Annual Report: U.S. Geological Survey Open-File Report 2009-1043, 56 p. (Also available at http://pubs.usgs.gov/of/2009/1043/.)

Crandall, J.D., 2004, Williamson River Delta restoration project-Catostomid technical report: The Nature Conservancy, $14 \mathrm{p}$.

Daraio, J.A., Randle, T.J., and Bach, L.B., 2004, Lower Williamson River floodplain and delta restoration-hydraulic modeling: Denver, Colo., Bureau of Reclamation Technical Services Center.

David Evans and Associates, Inc., 2005, Williamson River Delta Restoration Environmental Impact Statement: Portland, Oreg. David Evans and Associates, Inc., 187 p.

Ellsworth, C.M., Luton, C.D., Tyler, T.J., VanderKooi, S.P., and Shivley, R.S., 2007, Spawning migration movements of Klamath large scale, Lost River, and shortnose suckers in the Williamson and Sprague Rivers, Oregon, prior to the removal of Chiloquin Dam-2005 annual report: U.S. Geological Survey, Klamath Falls, Oreg., 42 p.

Ellsworth, C.M., Tyler, T.J., VanderKooi, S.P., and Markle, D.F., 2009, Patterns of larval sucker emigration from the Sprague and Lower Williamson Rivers, Oregon, prior to the removal of Chiloquin Dam - 2006 annual report: U.S. Geological Survey Open-File Report 2009-1027, 32 p. (Also available at http://pubs.usgs.gov/of/2009/1027/.)

Elseroad, A., Nathan R., and Hendrixson, H., 2010, Williamson River Delta Preserve vegetation monitoring: Goose Bay first-year post-breaching results: The Nature Conservancy, Oregon, $10 \mathrm{p}$.

Hendrixson, H.A., 2008, Non-native fish species and Lost River and shortnose suckers use of restoration and undisturbed wetlands at the Williamson River Delta-Final report of activities conducted in 2006 and 2007: Report of The Nature Conservancy to the U.S. Fish and Wildlife Service, Klamath Falls, Oreg., 28 p.

Hendrixson, H.A., Burdick, S.M., and VanderKooi, S.P., 2007, Near-shore and offshore habitat use by endangered, juvenile Lost River and shortnose suckers in Upper Klamath Lake, Oregon-Annual Report 2004: Report of U.S. Geological Survey, Western Fisheries Research Center, Klamath Falls Field Station to Bureau of Reclamation, Mid-Pacific Region, Klamath Falls, Oreg.

Kelso, W.E., and Rutherford, D.A., 1996, Collection, preservation, and identification of fish eggs and larvae in Murry, B.R., and Willis, D.W., eds., Fisheries techniques, 2nd ed.: Bethesda, Maryland, American Fisheries Society, p. 255-302.

Lindenberg, M.K., Hoilman, Gene, and Wood, T.M., 2008, Water-quality conditions in Upper Klamath Lake and Agency Lakes, Oregon, 2006: U.S. Geological Survey Scientific Investigations Report 2008-5201, 23 p. (Also available at http://pubs.usgs.gov/sir/2008/5201/.)

Markle, D.F., Reithel, S.A., Crandall, J., Wood, T., Tyler, T., Terwilliger, M., and Simon, D.C., 2009, Larval fish transport and retention and the importance of location for juvenile fish recruitment in Upper Klamath Lake, Oregon: Transactions of the American Fisheries Society, v. 138, p. 328-347, doi: 10.1577/T07-274.1, accessed August 13, 2010, at http://afsjournals.org/doi/abs/10.1577/T07274.1. 
Markle, D.F., and Simon, D.C., 1993, Preliminary studies of systematics and juvenile ecology of Upper Klamath Lake Suckers-Final Report: Corvalis, Oreg., Oregon State University.

National Research Council, 2004, Endangered and threatened fishes in the Klamath River BasinCauses of decline and strategies for recovery: Washington, D.C., The National Academies Press, 398 p.

The Nature Conservancy, 2009, Continuous physical water chemistry monitoring in water-quality conditions on the Williamson River Delta, Oregon-One Year Post-Restoration: Klamath Falls, Oreg., The Nature Conservancy, Klamath Basin Field Office.

The Nature Conservancy, 2010, 2009 water-quality conditions on the Williamson River Delta, Oregon-Two years post-restoration: Klamath Falls, Oreg., The Nature Conservancy, Klamath Basin Field Office.

Simon, D.C., and Markle, D.F., 2002, Ecology of Upper Klamath Lake shortnose and Lost River suckers-Annual survey of abundance and distribution of age-0 shortnose and Lost River suckers in Upper Klamath Lake-2001 Annual Report: Report of Oregon Cooperative Research Unit, Department of Fisheries and Wildlife, Oregon State University to U.S. Biological Resources Division, U.S. Geological Survey, Corvallis, Oreg. and Klamath Project, Bureau of Reclamation, Klamath Falls, Oreg.

Sullivan, A.B., Deas, M.L., Asbill, J., Kirshtein, J.D., Butler, K., and Vaughn, J., 2009, Klamath River water quality data from Link River Dam to Keno Dam, Oregon, 2008: U.S. Geological Survey OpenFile Report 2009-1105, 25 p.

Wood, T.M., Hoilman, G.H., and Lindenberg, M.K., 2006, Water quality conditions in Upper Klamath Lake, Oregon, 2002-2004: U.S. Geological Survey Open-File Report 2006-5209, 49 p.

Wood, T.M., Cheng, R.T., Gartner, J.W., Hoilman, G.H., Lindenberg, M.K., and Wellman, R.E., 2008, Modeling hydrodynamics and heat transport in Upper Klamath Lake, Oregon, and implications for water quality: U.S. Geological Survey Scientific Investigations Report 2008-5076, 48 p. (Also available at http://pubs.usgs.gov/sir/2008/5076/.) 


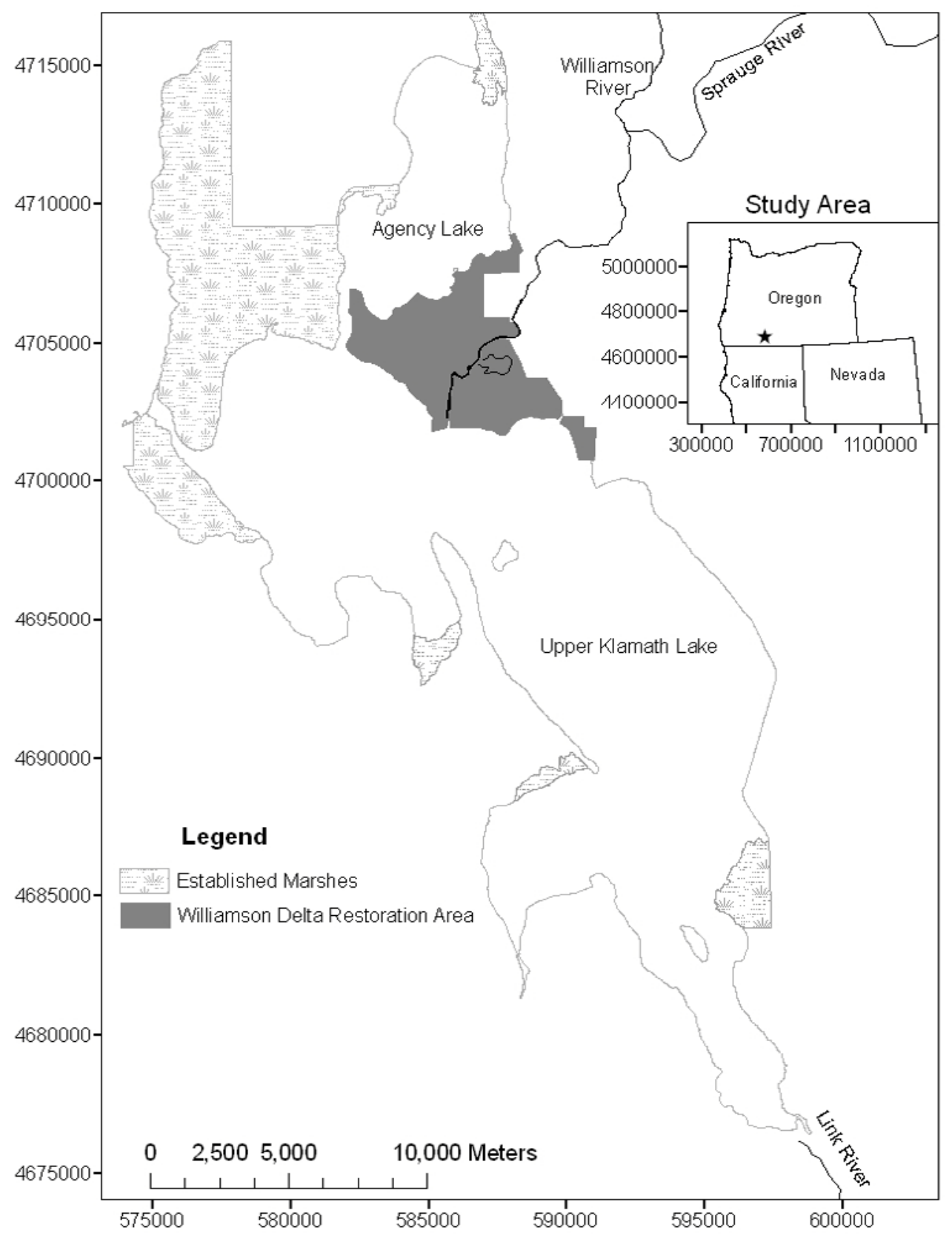

Figure 1.1. Geographic location of Williamson River Delta in relation to other aquatic environments and state boundaries. Coordinate information is referenced to the Western Geographic System of 1984 (WGS84). The map coverage for the Williamson River Delta restoration area was provided by The Nature Conservancy. 


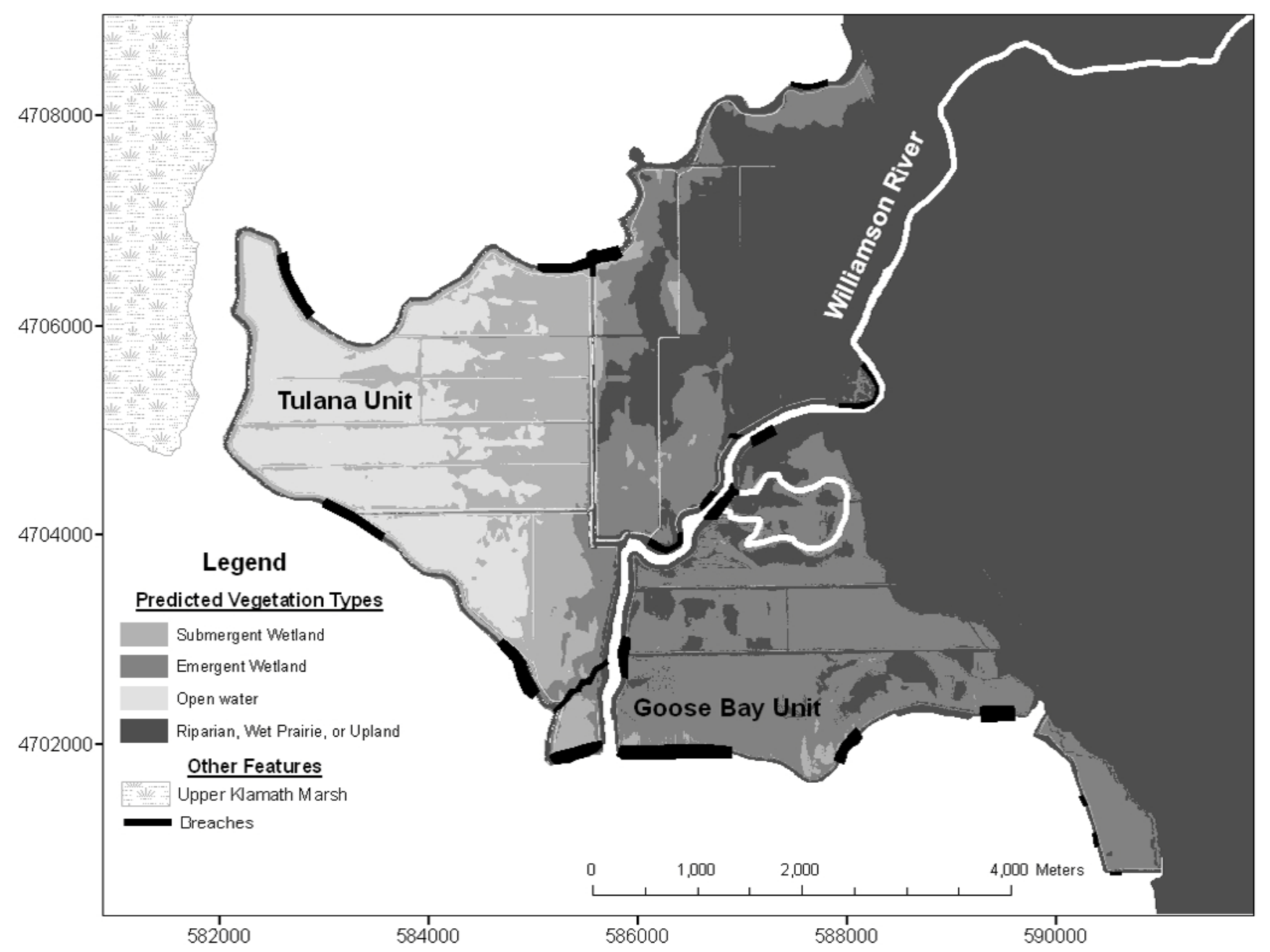

Figure 1.2. Map of the Williamson River Delta including predicted vegetation types expected to develop under below average water year conditions (David Evans and Associates Inc., 2005). Map layers for vegetation types and the locations of excavated dikes (breaches) were provided courtesy of The Nature Conservancy. Coordinate information is referenced to the Western Geographic System of 1984 (WGS84). 
Table 1.1. Plant communities predicted to develop in the Williamson River Delta (David Evans and Associates Inc., 2005).

[The potential for each of these communities to become habitat for endangered larval or juvenile Lost River or shortnose suckers is given]

\begin{tabular}{lccc}
\hline $\begin{array}{c}\text { Predicted plant } \\
\text { community }\end{array}$ & $\begin{array}{c}\text { Maximum } \\
\text { depth }(\mathrm{m})\end{array}$ & $\begin{array}{c}\text { Potential habitat } \\
\text { for larval } \\
\text { suckers }\end{array}$ & $\begin{array}{c}\text { Potential habitat } \\
\text { for juvenile } \\
\text { suckers }\end{array}$ \\
\hline Upland & 0.2 & No & No \\
Riparian & 0.6 & Yes & No \\
Emergent Wetland & 1.5 & Yes & Yes \\
Deep Water Wetland & 2.7 & Yes & Yes \\
Open Water & 4.0 & Yes & Yes \\
\hline
\end{tabular}




\section{Chapter 2-Larval Fish Retention and Distribution}

\section{Introduction and Background}

The Upper Klamath Lake populations of Lost River and shortnose suckers exhibit spawning migrations to springs on the eastern shore of Upper Klamath Lake, the lower Williamson River, or the Sprague River between March and May (Ellsworth and others, 2007). Eggs are spread over gravel and cobble substrates (Andreasen, 1975). Between mid-April and late May, larvae spawned in the river systems emerge from gravel and drift downstream to the Williamson River Delta (Ellsworth and others, 2009). By June, most young-of-the-year suckers have developed fin rays and other morphological characteristics of adults, at which point they are considered juveniles (Kelso and Rutherford, 1996; Ellsworth and others, 2009).

The Williamson River Delta straddles the last 4 miles of the Williamson River, and a primary goal of the restoration project was to provide high quality rearing habitat for larval suckers. Prior to the restoration of the Williamson River Delta, Cooperman and Markle (2000) found that sucker larvae rapidly exited the Williamson River and often entered Upper Klamath Lake without the development of a caudal fin, causing difficulties in foraging and swimming. Subsequently, Markle and others (2009) found that sucker larvae could be transported from the mouth of the Williamson River to the lake outlet within 8-17 days. Cooperman and Markle (2004) determined that established wetlands composed of emergent macrophytes support more, larger, and better-fed larvae than wetlands composed of submergent macrophytes, woody vegetation, or open water. Larval suckers began rearing in two pilot restoration wetlands near the Williamson River Delta within a single season (Crandall and others, 2008; Hendrixson, 2008). They also found that larval densities were greater in vegetated environments. After the Williamson River Delta was reconnected to adjacent lake environments in 2008, larger and better fed larvae were consistently captured within the delta than in previously existing wetland habitats (Erdman and Hendrixson, 2009) or adjacent lake environments (Burdick and others, 2009a).

Preliminary hydrodynamic models predict that localized densities of passively drifting particles originating in the Williamson River are most affected by the initial density of particles in the river, wind direction and speed, lake surface elevation, and river discharge, in that order (T. Wood, USGS, written commun., 2010). These models predict that wind blowing from the north and west pushes more water into Goose Bay, whereas wind blowing from the south and east pushes more water into the Tulana Unit (T. Wood, U.S. Geological Survey, written commun., 2010). Higher lake-surface elevations are associated with longer retention times for passive particles in the Williamson River Delta compared to lower lake-surface elevations (Wood, 2009). These models also predict that high river discharge pushes a greater proportional volume of water from the Williamson River out its mouth rather than across the delta (T. Wood, U.S. Geological Survey, written commun., 2009). These models are still under development, and do not yet incorporate larval fish behavior. 
In cooperation with The Nature Conservancy (TNC) and USGS's Oregon Water Science Center, we developed a two part sampling strategy to describe the geographic and temporal use of the restored Williamson River Delta by larval suckers (objective 1). One part of the study was designed specifically to compare spatial distribution, relative abundance, and condition of larval suckers in newly restored and existing wetland habitats of the delta to adjacent lake environments. The other part of the study was designed to examine the influence of hydrodynamic processes on larval transport and residence time in the restored habitat. We also sought to characterize the larval fish community within the Williamson River Delta.

\section{Methods}

\section{Random Stratified Sampling}

For the first part of this study, we randomly selected sites for sampling in several habitat types across the delta. The Nature Conservancy sampled in shallow habitats $(<1 \mathrm{~m}$, table 2.1$)$, located on the eastern side of the Tulana Unit and throughout the Goose Bay Unit (fig. 1.2), using 1.6-m square pop nets outfitted with fine mesh nylon (Erdman and Hendrixson, 2009). This gear type allowed sampling of the entire water column in environments with and without vegetation. To complement their monitoring program, we used a random stratified sample design to select sites from three deep ( $>1.5 \mathrm{~m}$ deep) and two shallow (0.5-1.1 m deep) strata: (1) Agency Lake, (2) Tulana Open Water, (3) Upper Klamath Lake, (4) Tulana Emergent, and (5) Tulana Submergent (fig. 1.2). We sampled 8-12 sites weekly between May 4 and July 8 with surface-plankton nets. Effort was initially equally divided among the first four strata. Then, as the Tulana Emergent strata became inaccessible due to declining lake-surface elevation, effort was reallocated to the Tulana Submergent stratum.

\section{Fixed Site Sampling}

For the second portion of this study, sample locations were selected based on hydrodynamic model predictions of distributional patterns of larval sucker age and density (T. Wood, U.S. Geological Survey, written commun., 2007). We selected fixed sample sites predicted to provide the greatest contrast in mean larval sucker age and density. We sampled 10 fixed sites in water greater than $1 \mathrm{~m}$ deep weekly from May 4 to July 8 . Our fixed sites were located on the lake side of breaches 3, 4, 5, and 6 , in open water in the Tulana Unit between breaches 4 and 5, in about $1 \mathrm{~m}$ of water on the east side of the Tulana Unit, within the Goose Bay Unit oxbow, near-shore in the western part of Goose Bay (Goose Bay West), off-shore in the eastern part of Goose Bay (Goose Bay East), and at the mouth of the Williamson River (fig. 2.1).

Fixed larval sampling sites not only varied in distance from the Williamson River (fig. 2.1), the source of most larval suckers, but also in depth and vegetative cover. Mean depth was shallowest at Breach 4 and the Tulana Emergent sites, deepest at Breach 3 and the Williamson River mouth site, and intermediate at the remaining six sites (table 2.1). Fixed sites located along the breaches were characterized by prominent tule beds and variable substrate. The Tulana Open Water site featured patches of submerged willows and fine substrate mixed with decomposing upland plant species. The Tulana Emergent site had patches of tule. The Goose Bay Oxbow site had isolated patches of coontail (Ceratophyllum demersum). The Goose Bay East, Goose Bay West, and Williamson Mouth sites were characterized by open water without vegetation. 


\section{Larval Sample Collection}

Plankton nets were used to collect larvae from the top of the water column. These nets had $0.3-\mathrm{m}$ diameter mouth openings, a 2.5-m long tail, 800- $\mu \mathrm{m}$ mesh Nitex netting, and a removable cod end. A General Oceanics model 2030R mechanical flow meter was mounted in the mouth of each net so that the volume sampled could be calculated. The net was towed parallel to a boat at approximately $1 \mathrm{~m} / \mathrm{s}$ for 3-5 minutes or until algae began to clog the mesh. After retrieval, all material was meticulously removed from nets and samples were immediately preserved in 70-95 percent ethanol. We also recorded water temperature, water depth, and the area covered by vegetation.

We collected three replicate tows at 19 percent of our sites to assess sampling efficiency. We varied the direction of the three tows so that the exact same volume of water was not sampled in each replicate. Catch rate variability of the replicates samples was examined.

In the laboratory, fish were identified to species or lowest taxonomic unit practical. Larval fish were identified using gut length, body shape, and pigmentation (D. Simon, Oregon State University, written commun., 2004; Remple and Markle, 2005). Using this method, larval suckers were identified as Lost River or a group of either shortnose or Klamath largescale suckers (SNS-KLS). Sculpin (Cottus spp.) were identified to genus due to the lack of a suitable larval identification key for these species. The notochord lengths (NL) of the first 10 larvae of each non-sucker species and all larval suckers were measured and all larval fish were enumerated. Larval density for each species was calculated by dividing the total number of fish in each sample by the volume of water filtered. Gut fullness was recorded for each sucker larvae as a percentage of the gut length that was $0,25,50,75$, or 100 percent full (Erdman and Hendrixson, 2009). We also noted the stage of each larval sucker (Buettner and Scoppettone, 1990).

\section{Larval Otolith Aging}

Following methods described by Hoff and others (1997), lapillus otoliths were extracted from preserved sucker larvae and mounted on slides using cyanoacrylate fast-acting adhesive. Mounted otoliths were polished by hand using a Buehler polishing disc and photographed under a $20 \times$ magnification oil immersion lens. Daily growth rings on each photographed otolith were counted by at least two independent readers. Readers were not informed of the species or length of the fish from which otoliths were extracted or of the other reader's ring counts to ensure unbiased ring counts. The reader's counts were compared and any differences greater than three were recounted by a third independent reader. If the third reader did not age the fish within 2 days of at least one of the other two readers, then the age was not used in this analysis. Ages were assigned by calculating the mean of the two closest readings. If all three readings were equally different then the median reading was used. Our otolith readers identified their confidence in each reading on a scale from 0 (no confidence) to 3 (total confidence), based on methods described by Koch and others (2008). If the median confidence rating among readers was zero, ring count data from the larvae was not considered in summary statistics but was included in figures showing aging precision. The notochord length for each larval sucker was then divided by age for each fish to provide a rough condition index. 
Wind, River Discharge, and Lake-Surface Data

We used date and location specific data on hydrology and wind to help describe hydrodynamic conditions experienced by larval suckers during our sampling period. We used wind data collected at a USGS meteorological station located on the west shore of the Williamson River mouth (station No. 422807121500), lake-surface elevation data from a USGS gaging station located near Rattlesnake Point (station No. 11505900), and river flow data from a USGS gaging station near Chiloquin, Oregon (station No. 11502500).

\section{Summarizing Data}

We summarized larval catch data to describe spatial and temporal patterns in larval sucker presence, density, length, age, and gut fullness. Density was calculated as the number of larvae per cubic meter. Because we had separate goals for random stratified sampling and fixed site sampling, we summarized these two datasets separately. We compared the use of lake habitats to newly restored delta habitats by summarizing data from random stratified sampling. We examined the importance of hydrodynamic conditions relative to the larval drift period in determining larval distribution by summarizing larval sucker densities and ages at fixed sites. To avoid a negative bias in calculations of mean sample density and the percentages of sites where fish were detected, we only used samples collected on or after the first day that each sucker taxa was first collected.

We summarized sample density of all non-sucker fish species to describe fish community structure and distribution. To avoid a negative bias in calculations of mean sample density and the percentages of sites where fish were detected, we only used samples collected on or after the first day that each species or taxa was first collected. Because all species except sculpin were detected on our last day of sampling, we did not truncate our dataset.

\section{Results}

\section{Spatial Patterns in Relative Abundance, Condition, and Age of Larval Suckers}

We collected 175 larval samples at 104 sites between May 4 and July 8 from six strata. The average $( \pm \mathrm{SD})$ volume of water filtered per site was $14.4 \pm 14.2$ per cubic meter. Single tows were collected at 69 sites and replicate tows were collected from 35 sites. SNS-KLS made up 90 percent of sucker larvae and were captured in 11 percent of sites. Three suckers could not be identified to species due to lack of identifying characteristics. Lost River suckers made up 7 percent of the sucker larvae and were captured at 6 percent of sites. Both sucker taxa occurred in only two of our random stratified samples. The overall mean $( \pm \mathrm{SD})$ density (larvae per cubic meter of water filtered) in samples collected between May 18 (the date of first capture) and July 6 (the date of last capture) was $0.06 \pm 0.27$ for SNSKLS compared to only $0.004 \pm 0.018$ for larval Lost River suckers.

Both groups of sucker larvae first appeared in our samples in during the week of May 18 (fig. 2.3). Lost River suckers were first captured in Agency Lake, Upper Klamath Lake, and Tulana Open Water strata. The following week, Lost River suckers were detected in the Tulana Emergent stratum, but were never detected in the Tulana Submergent stratum. SNS-KLS were first captured in the Agency Lake and Tulana Emergent strata. The following week larvae from this group were captured in Upper Klamath Lake, but were never detected in the Tulana Open Water or Tulana Submergent strata. After initial capture, SNS-KLS catch rate was variable in the Upper Klamath Lake and Tulana Emergent strata. 
The percentage of sampling sites where Lost River suckers were detected was greatest in the Tulana Emergent stratum ( 25 percent) followed by Tulana Open Water (9 percent), then Agency Lake ( 5 percent) and Upper Klamath Lake strata (4 percent). The percentage of sampling sites with SNS-KLS was greatest in the Tulana Emergent stratum (63 percent) followed by Upper Klamath Lake (19 percent) and Agency Lake (5 percent) strata. Differences in mean sample density of Lost River and SNS-KLS larvae among sampling strata were minor (table 2.2).

Seventy-six percent of SNS-KLS and 50 percent of Lost River sucker larvae had food in their guts, but there was variation in gut fullness among strata (tables 2.3 and 2.4). Seventy-two percent of SNS-KLS had guts between 25 and 75 percent full, 21 percent had empty guts, and 7 percent had full guts. Fifty one percent of larval Lost River suckers had guts 25 to 50 percent full and 50 percent had empty guts. Median gut fullness for SNS-KLS was highest in the Upper Klamath Lake stratum (37.5 percent full), intermediate in the Tulana Emergent stratum (25.0 percent full), and lowest in the Agency Lake stratum (12.5 percent full). Lost River sucker median gut fullness was highest in the Tulana Emergent stratum (25.0 percent full) and lowest in the Tulana Open Water stratum (12.5 percent full; table 2.3). SNS-KLS larvae with empty guts were caught in Agency Lake (1 fish), Upper Klamath Lake (3 fish), and Tulana Emergent (16 fish) between May 18 and June 9. Lost River sucker larvae with empty guts were caught in Agency Lake (1 fish), Tulana Emergent (1 fish), and Tulana Open Water (2 fish) between May 18 and May 28. We found no correlations between gut fullness and length or age of sucker larvae.

The mean notochord length $( \pm \mathrm{SD})$ for Lost River suckers (12.48 $\pm 0.67 \mathrm{~mm}$ NL, 8 fish) was only slightly higher than for SNS-KLS larvae (12.22 $\pm 1.19 \mathrm{~mm} \mathrm{NL}, 98$ fish). All sucker larvae were mesolarvae in various stages of flexion or post flexion (Buettner and Scoppettone, 1990). We assigned ages to 7 Lost River sucker larvae and to 74 SNS-KLS larvae in our random stratified larval sampling. The mean age $( \pm \mathrm{SD})$ for Lost River suckers (13.0 \pm 2.4 days) was slightly higher than SNS-KLS larvae (11.3 \pm 1.7 days). There was a significant but weak relation between length and age of SNS-KLS larvae $\left(R^{2}=0.15 ; \mathrm{P}<0.001 ;\right.$ fig. 2.4). We did not capture enough Lost River suckers to derive a relationship between age and length. Most SNS-KLS larvae (95 percent) were captured in the Tulana Emergent stratum so no among-strata comparisons were made. Comparisons between strata also were not made for Lost River sucker larvae due to the small number captured.

\section{Larval Sucker Distribution, Condition, and Sample Density along Predicted Hydrodynamic Pathways}

Larval suckers passed through the delta under various environmental conditions that could potentially influence their distribution. Larvae occurred between early May and mid-July and were most dense between mid-May and early June. Wind speed and direction varied greatly, but were generally between 0.5 and $4.0 \mathrm{~m} / \mathrm{s}(1.6-13.1 \mathrm{f} / \mathrm{s})$ from the northwest. Our sampling encompassed the peak discharge from the Williamson River Delta, $49.8 \mathrm{~m}^{3} / \mathrm{s}\left(1,760 \mathrm{ft}^{3} / \mathrm{s}\right)$ on May 11. Most of our sampling, however, occurred during the declining limb of the hydrograph $\left(49.8-14.4 \mathrm{~m}^{3} / \mathrm{s} ; 1,760-507 \mathrm{ft}^{3} / \mathrm{s}\right)$. Lakesurface elevations remained fairly constant, declining from $1,262.74$ to $1,262.37 \mathrm{~m}(4,142.85-4,141.63$ ft) during our sampling. 
We collected 155 samples between May 4 and July 8 from 10 fixed sites that were visited weekly. Single tows were taken on 71 occasions and replicate tows were taken on 28 occasions. We collected 66 Lost River sucker larvae and 70 SNS-KLS larvae from our fixed site samples. Three individuals were not identifiable to any taxa other than Catostomidae due to lack of identifying characteristics. SNS-KLS suckers were caught at all 10 fixed sites, but Lost River suckers were only captured at 5 of the 10 sites. Both sucker taxa occurred in only 6 percent of our fixed site samples. The overall mean $( \pm \mathrm{SD})$ density in fixed site samples collected between May 15 (first day larvae were detected) and July 6 (last day larvae were detected) was $0.05 \pm 0.15$ for larval Lost River suckers as compared to $0.07 \pm 0.13$ for larvae identified as SNS-KLS larvae.

Most Lost River sucker larvae caught in our fixed site sampling were captured at the Goose Bay West (36 percent) site. Of these, 62 percent were captured on May 21 when water temperature was 15 ${ }^{\circ} \mathrm{C}$. Lost River sucker catches coincided with the declining limb of the hydrograph when discharge from the Williamson River was 33.7-36.8 $\mathrm{m}^{3} / \mathrm{s}\left(1,190-1,300 \mathrm{ft}^{3} / \mathrm{s}\right.$; fig. 2.5), below the seasonal peak. Lost River sucker larvae also were captured at the Williamson River mouth (29 percent), at Goose Bay Oxbow (20 percent), at Tulana Emergent (9 percent), and at Goose Bay East (6 percent) sites in late May and early June (fig. 2.6).

SNS-KLS larvae were more evenly distributed with the majority captured in Goose Bay Oxbow (29 percent), Tulana Emergent (27 percent), or Goose Bay West (24 percent). This group also was captured at the Goose Bay East ( 9 percent), Williamson River mouth (4 percent), Breach 6 (4 percent), Tulana Open Water (1 percent), Breach 3 (1 percent), and Breach 5 (1 percent) sites. SNS-KLS larvae were captured in our fixed site sampling between May 15 and July 6 when water temperature was between 11 and $25^{\circ} \mathrm{C}$ (fig. 2.6). The presence of SNS-KLS larvae also coincided with the declining limb of the hydrograph when discharge from the Williamson River decreased from 35.1 to $14.7 \mathrm{~m}^{3} / \mathrm{s}$ (1,240 to $522 \mathrm{ft}^{3} / \mathrm{s}$; fig. 2.5).

Seventy-four percent of larval Lost River suckers and 80 percent of SNS-KLS larvae caught in our fixed site sampling had some food in their digestive systems, but there was some variation in median gut fullness among sites (tables 2.5 and 2.6). More than two-thirds of both larval sucker taxa with empty digestive systems were caught at the Goose Bay West fixed site. For Lost River suckers, median gut fullness was highest at the Tulana Emergent (50.0 percent) and Williamson River Mouth (50.0 percent) sites, intermediate at the Goose Bay East (25.0 percent) and Goose Bay Oxbow (25.0 percent) sites, and lowest at the Goose Bay West (0.0 percent) site. For the group of larvae identified as either SNS-KLS larvae, median gut fullness was highest at the Goose Bay East (62.5 percent) and Breach 6 (50.0 percent) sites, intermediate at the Goose Bay Oxbow (37.5 percent), Tulana Emergent (25.0 percent), and Williamson Mouth (25.0 percent) sites, and lowest at the Goose Bay West (0.0 percent) site. Single larvae from this group also were caught with food in their digestive systems at Breach 3 (100.0 percent), Breach 5 (25.0 percent), and in the Tulana Open Water (25.0 percent) strata. 
The mean length ( \pm SD) for larval Lost River suckers $(12.17 \pm 0.89 \mathrm{~mm}$ NL, 66 fish) was slightly lower than for SNS-KLS larvae (12.59 $\pm 1.42 \mathrm{~mm} \mathrm{NL}, 70$ fish) captured in our fixed site sampling (table 2.7). We assigned ages to 42 Lost River sucker larvae and to 47 SNS-KLS larvae in our fixed larval sampling. The mean $( \pm \mathrm{SD})$ age was $11.8 \pm 1.9$ days for Lost River sucker larvae and $12.2 \pm$ 3.4 days for the group of SNS-KLS larvae. A comparison of mean $( \pm \mathrm{SD})$ length to age ratios indicates that Lost River sucker larvae (1.06 \pm 0.13$)$ and SNS-KLS larvae $(1.05 \pm 0.14$, table 2.8$)$ had similar lengths for their age. On average (mean \pm SD), the largest SNS-KLS larvae for their age were found at the Goose Bay East site, although the largest Lost River larvae for their age were found at the Goose Bay Oxbow site (table 2.8). The smallest, on average (mean $\pm \mathrm{SD}$ ), larvae for their age were found at the Williamson Mouth site for SNS-KLS larvae, and at the Tulana Emergent for Lost River sucker larvae (table 2.8). There was a weak relation between length and age data for both Lost River suckers and the group of SNS-KLS larvae (fig. 2.7).

\section{Spatial and Temporal Patterns in the Larval Fish Community}

We captured five non-sucker fishes common to Upper Klamath Lake in our random stratified sampling and fixed site sampling. We identified 4,278 larval fish that were not suckers, of these 24 were not identifiable due to poor preservation. Mean $( \pm \mathrm{SE})$ sample densities were very high for fathead minnow (2.38 \pm 5.89$)$ and tui chub (Gila bicolor; $2.24 \pm 5.59)$, intermediate for blue chub (Gila coerulea; $0.94 \pm 2.07)$, and low for yellow perch $(0.03 \pm 0.45)$. The least common taxon in our larval sampling was sculpin, which was only detected at one sample site in Tulana Open Water on May 18.

The species composition of the non-sucker larval community closely resembled that of the juvenile and small adult fish community in the Williamson River Delta (see chapter 2). The first nonsucker larvae to be detected in our sampling were non-native fathead minnow and yellow perch, during the week of May 4 (fig. 2.8). Native blue and tui chub were first captured during the following week. Yellow perch were a small portion of overall larval catch; however, they were captured in relatively high numbers in the Tulana Emergent stratum during the week of May 11 (fig. 2.8). Blue chub made up most of the catch in the Tulana Emergent stratum and at the Breach 6 fixed site during the week of May 25. Non-sucker catch rates began to increase in June, after which fathead minnow and tui chub dominated larval catches in every strata (figs. 2.8 and 2.9).

\section{Larval Sucker Sample Efficiency}

There was a high degree of variability in sample densities between replicate tows at sites for Lost River sucker larvae and SNS-KLS larvae. Lost River sucker larvae were captured at 13 percent and SNS-KLS larvae were captured at 19 percent of replicate tow sites. Lost River suckers were detected in all three replicate tows on only one occasion and in two of three tows on two occasions. SNS-KLS larvae were captured in all three replicate tows on two occasions and in two of three tows on two occasions. The mean $( \pm \mathrm{SD})$ difference between the highest and lowest sample densities among replicates when at least one larvae was caught was $0.19 \pm 0.03$ larvae per cubic meter for Lost River suckers and $0.34 \pm 0.07$ larvae per cubic meter for SNS-KLS larvae. Larval density in our sample did not decrease with each sequential tow, suggesting repeat tows did not bias our assessment of sampling efficiency. 


\section{Precision and Confidence of Larval Aging Data}

Using ring counts from lapillus otoliths, we aged 51 Lost River suckers and 125 shortnose suckers ( 85 percent of the total captured). Confidence ratings averaged (mean \pm SD) $1.00 \pm 0.14$ for Lost River suckers and $1.12 \pm 0.11$ for SNS-KLS suckers, indicating little confidence in the aging structures. Agreement between our readers was strong with only 18 percent of readings differing by three or more, which required a third reader (fig. 2.2). Of those, only 10 percent were excluded from analysis due to inconsistent ring identification or a median confidence index of zero. Fitting lines to ring count data collected by the first two independent readers of the same structures resulted in a $R^{2}=0.60$ for Lost River suckers and a $R^{2}=0.37$ for shortnose suckers.

\section{Discussion}

Larval Sucker Habitat Use, Relative Abundance, and Condition in the Williamson River Delta and Adjacent Lake Environments in 2008 and 2009

Mean sample density in our random stratified sampling was approximately 15 times greater in 2008 than in 2009 for Lost River suckers and 4 times greater in 2009 than in 2008 for SNS-KLS larvae. The difference in sample density among years probably is a result of differential larval production in the river, larval survival, retention in the Williamson River Delta, or a combination of these. Williamson River larval sucker densities for both taxa were greater in the Williamson River in 2009 than in 2008 (Burdick and others, 2009b), indicating that differential production among years may have influenced sample densities of SNS-KLS larvae, but probably did not have a major influence on densities of Lost River sucker larvae in the delta.

A comparison of relative abundance for larval suckers caught in our random stratified sampling in the delta and adjacent lake environments in 2008 and 2009 indicates larval suckers used the delta more than adjacent lake environments in both years. The same comparisons made between strata within the delta indicated that Lost River sucker larvae were found more often in deeper more westerly strata than SNS-KLS larvae in 2009, but results were equivocal in 2008. Mean sample density was greater for both species in the Williamson River Delta than adjacent lake habitats in 2008 and 2009. Within the Williamson River Delta, sample density was greatest for SNS-KLS larvae in the Tulana Emergent stratum and greatest for Lost River suckers in the Tulana Open Water stratum in 2009. Sample density for SNS-KLS larvae was greatest in the Tulana Emergent stratum and was equally high for Lost River sucker larvae in the Tulana Emergent and Upper Klamath Lake strata in 2008. Decreasing larval density from east to west may be because larvae disperse with increasing distance from the Williamson River, the source of most larvae. Larval suckers also may be selecting shallow habitats on the east side of the delta. A better understanding of how environmental conditions and habitat structure effect the distribution, abundance, and condition of larval suckers as compared to surrounding lake environments requires further examination. 
A comparison of gut fullness for larval suckers caught in our random stratified sampling in the delta and adjacent lake environments in 2008 and 2009 indicated that feeding conditions varied among strata and species. Median gut fullness was greater in the Williamson River Delta than in either of the adjacent lakes for Lost River suckers in both 2008 and 2009. Median gut fullness for SNS-KLS larvae was greatest in the Upper Klamath Lake and Agency Lake strata in 2008, but greatest in the Upper Klamath Lake stratum and lowest in the Agency Lake stratum in 2009. Overall median gut fullness was greater for both species in 2008 than in 2009, but this assessment is subjective and could be biased due to a change in technicians between years. Lower gut fullness for larval suckers captured in our sampling in 2009 may indicate our study area provided less favorable feeding conditions in 2009 than 2008. Mean water temperature during early May was $4{ }^{\circ} \mathrm{C}$ cooler in 2009 than in 2008, which may have influenced the availability of prey items and could explain annual differences in gut fullness.

\section{Larval Sucker Distribution, Transport, and Residence Time Relative to Hydrodynamic Conditions}

Making the assumption that larval suckers primarily behave like passive particles, and applying the basic principles from preliminary hydrodynamic models, we predicted general patterns in larval sucker distribution for the spring of 2009 (T. Wood, U.S. Geological Survey, written commun., 2010). The most recent hydrodynamic models indicate that the distribution of larval suckers in the Williamson River Delta depends on a number of hydrodynamic and biological conditions including production of sucker larvae in the Williamson River, wind direction and speed, lake elevation at the time larvae enter the delta, and river flows during larval drift. The most frequent wind direction in both 2008 and 2009 generally was from the northwest. Lake-surface elevation peaked in 2009 at $1262.74 \mathrm{~m}(4,142.85 \mathrm{ft})$ in mid-May, although lake-surface elevation did not peak until early June in 2008, at 1,262.82 m (4,143.11 $\mathrm{ft}$ ). Discharge from the Williamson River differed greatly between 2008 and 2009. A single peak occurred in early May of 2009, although discharge peaked twice in 2008 with sustained values at or near the 2009 peak discharge until early June. The individual effect of these conditions is uncertain. With continued sampling and collaboration with TNC, Oregon State University, and the Oregon Water Science Center, we may be able to determine their combined effect on larval sucker density and distribution in the Williamson River Delta.

Preliminary data indicates that the timing of larval drift relative to these hydrodynamic conditions influences the spatial distribution of larval suckers throughout the Williamson River Delta. In 2008, high numbers of Lost River sucker larvae were captured at the mouth of the Williamson River possibly due to a combination of relatively high outflow and downstream drift timing. SNS-KLS larvae arrived later under lower flows and were captured in greater numbers in the Tulana Emergent stratum in 2008. In 2009, both Lost River sucker larvae and SNS-KLS larvae drifted downstream after peak outflow. Hydrodynamic modeling indicates that during high-flow events proportionally more of the Williamson River flow is directed out the mouth rather than across the delta (T. Wood, U.S. Geological Survey, oral commun., 2009). Conversely, when discharge is low, the Williamson River is more directed into the delta than out the mouth, which may explain the broad distribution of SNS-KLS larvae throughout the delta in 2008 and both sucker taxa in 2009. The addition of the Goose Bay Unit of the Williamson River Delta may have influenced spatial distribution as well by creating more accessible habitat on the down-wind side of the delta, based on prevailing wind conditions. While hydrodynamic modeling provides insight into larval travel pathways, low catch rates and the addition of the Goose Bay Unit also makes between-year comparisons difficult. With further years of data collection, we can increase our understanding of how hydrodynamic conditions influence larval distribution. 
Consistently low daily catches of larval suckers prevented us from learning much about their behavior. Larval suckers appear to exhibit a negative phototactic response that allows them to find the thalweg around sunset and slower velocity, shoreline areas around sunrise (Cooperman and Markle, 2003; Ellsworth and others, in press). It is unclear when this behavior ceases. Larvae may exit the drift when they first find food, encounter a high water temperature threshold, or at a certain developmental stage or age. We hope to determine if larval suckers continue to exhibit the negative phototactic behavior by sampling three sites after sunset in the Williamson River and main currents in the Williamson River Delta. This may increase our sample efficacy and refine our understanding of what triggers larval suckers to cease their nocturnal drift behavior.

\section{Larval Fish Community Characterization}

The larval fish community in the Williamson River Delta is similar to the juvenile and small adult fish community in the delta and adjacent lake habitats. Diversity of larvae was low because of the high abundance of fathead minnow and tui chub and small number of larval fish species. Mean sample densities of fathead minnow and tui chub larvae increased by more than two orders of magnitude between 2008 and 2009. Fathead minnows spawn in shallow, warm water over sand or silt substrates (Lane and others, 1996). Tui chub eggs have been observed in dense vegetation at depths of $1-3 \mathrm{~m}$ (Bird 1976) and interstitially in gravel substrate at shallow depths of 0.25 to $1 \mathrm{~m}$ (Cooper, 1982). These habitat types occur in both units of the Williamson River Delta but we have not observed spawning. Fathead minnow and tui chub larvae are abundant in the delta but we do not know where they spawn. We captured yellow perch larvae for the first time in the Williamson River Delta in 2009. Yellow perch larvae were not captured in the Williamson River Delta in water of less than $1 \mathrm{~m}$ deep in 2008 or 2009 (Burdick and others, 2009b; Erdman and Hendrixson, 2009). High mean weekly catches of the older cohort of yellow perch in the Tulana Emergent stratum between the weeks of May 3 and June 21 were observed in this area and some were in spawning condition (see chapter 2). Mean weekly larval yellow perch densities were never greater than 1.50 fish per cubic meter. These densities indicate that if spawning occurred it was not very productive. With the addition of night sampling, we hope to determine if non-sucker species spawn in the Williamson River Delta.

\section{Larval Sucker Sample Efficiency}

The number of random stratified sample sites was increased in 2009 from 2008; however, repeated sampling indicated our plankton net sampling efficiency was still inconsistent. Variable catch rates of replicate net tows suggest that larvae are not uniformly distributed and replicate net tows did not deplete larvae at each site. Therefore, these data should only be used to describe dominant distributional patterns and are not appropriate for estimating abundance. Given the high amount of variability in our sampling efficacy in 2009, we plan to collect replicate tows at all sites in 2010. 


\section{Quality of Larval Aging Data}

Our estimated larval ages were accurate but not precise. Our age estimates are in agreement with the timing for larval emergence and transport time reported by Cooperman and Markle (2000) and Markle and others (2009) suggesting our age estimates were correct. Inconsistency in larval lapilli otolith counts between and among readers and low confidence ratings, however, illustrate the difficulties in obtaining precise age estimates. Our inferences were sound for two reasons. First, we used lapilli otoliths, generally assumed to be the most readable bony structures, to age larvae. Secondly, we only used ring counts aged similarly by multiple readers. Therefore, our inferences were based on high quality data.

\section{Summary}

We summarized data in this chapter to compare spatial distribution, relative abundance, transport dynamics, and condition of larval suckers in the Williamson River Delta restoration area in 2009 to adjacent lake environments. Data was also summarized to compare the larval fish communities of the delta and adjacent lake environments. Gut fullness for Lost River suckers was greater in the Williamson River Delta than in Agency and Upper Klamath lakes in both 2008 and 2009. Gut fullness for SNS-KLS larvae was greatest in the Upper Klamath Lake and Agency Lake strata in 2008, but greatest in the Upper Klamath Lake stratum and lowest in the Agency Lake stratum in 2009. Data indicates that the timing of larval drift relative to hydrodynamic conditions influences the spatial distribution of larval suckers throughout the Williamson River Delta, but is probably one of many factors that determine larval sucker spatial distribution. The overall larval fish community in the Williamson River Delta was similar to the juvenile and small adult fish community in the delta and adjacent lake habitats. Larval diversity was low because of the high abundance of fathead minnow and tui chub and small number of larval fish species.

We assessed the precision of our sampling and larval aging techniques. Repeated sampling indicated our plankton net sampling efficiency was inconsistent, indicating data presented in this chapter should only be used to describe dominant distributional patterns. Our estimated larval sucker ages were judged to be accurate but not precise and should also be used only for the description of dominate patterns.

\section{References Cited}

Andreasen, James K., 1975. Systematics and status of the Family Catostomidae in southern Oregon. Ph.D. Thesis, Oregon State University, Corvallis, OR. 80 pp.

Bird, F.H., 1976, Biology of the blue and tui chubs in East and Paulina Lakes, Oregon:. Corvallis, Oregon, Oregon State University, Master's Thesis, $181 \mathrm{p}$.

Burdick, S.M., VanderKooi, S.P., and Anderson, G.O., 2009a, Spring and summer spatial distribution of endangered juvenile Lost River and shortnose suckers in relation to environmental variables in Upper Klamath Lake, Oregon: 2007 Annual Report: U.S. Geological Survey Open-File Report 2009-1043, 56 p. (Also available at http://pubs.usgs.gov/of/2009/1043/.)

Burdick, S.M., Ottinger, C., Brown, D.T., VanderKooi, S.P., Robertson, L., and Iwanowicz, D., 2009b, Distribution, health, and development of larval and juvenile Lost River and shortnose suckers in the Williamson River Delta restoration project and Upper Klamath Lake, Oregon: 2008 annual data summary: U.S. Geological Survey Open-File Report 2009-1287, 76 p. (Also available at http://pubs.usgs.gov/of/2009/1287/.) 
Buettner, M., and Scoppettone, G. 1990, Life history and status of Catostomids, in Upper Klamath Lake, Oregon: National Fisheries Research Center, Klamath Tribes, and Oregon Department of Fish and Wildlife, 108p.

Cooper, J.J., 1982, Observations on the reproduction and embryology of the lahontan tui chub, gila bicolor, in Walker Lake, Nevada: Great Basin Naturalist, v. 42, p. 60-64.

Cooperman, M.S., and Markle, D.F., 2000, Ecology of Upper Klamath Lake shortnose and Lost River suckers. 2. Larval ecology of shortnose and Lost River suckers in the lower Williamson River and Upper Klamath Lake: Department of Fisheries and Wildlife, Oregon State University, Corvallis, OR, $27 \mathrm{p}$.

Cooperman, M.S., and Markle, D.F., 2003, Rapid out-migration of Lost River and shortnose suckers from in-river spawning beds to in-lake rearing grounds: Transactions of the American Fisheries Society, v. 132, p. 1138-1153.

Cooperman, M.S., and Markle, D.F., 2004, Abundance, size, and feeding success of larval shortnose suckers and Lost River suckers from different habitats of the littoral zone of Upper Klamath Lake: Environmental Biology of Fishes, v. 71, p. 365-377.

Crandall, J.D, Bach, L.B., Rudd, N., Stern, M., and Barry, M., 2008, Response of Larval Lost River and shortnose suckers to wetland restoration at the Williamson River Delta, Oregon: Transactions of the American Fisheries Society, v. 137, p. 402-416.

Ellsworth, C.M., Luton, C.D., Tyler, T.J., VanderKooi, S.P., and Shivley, R.S., 2007, Spawning migration movements of Klamath large scale, Lost River, and shortnose suckers in the Williamson and Sprague Rivers, Oregon, prior to the removal of Chiloquin Dam: 2005 annual report: U.S. Geological Survey, Klamath Falls, Oregon, 42 p.

Ellsworth, C.M., Tyler, T.J., VanderKooi, S.P., and Markle, D.F., 2009, Patterns of larval sucker emigration from the Sprague and Lower Williamson Rivers, Oregon, prior to the removal of Chiloquin Dam -2006 annual report: U.S. Geological Survey Open-File Report 2009-1027, 32 p. (Also available at http://pubs.usgs.gov/of/2009/1027/.)

Ellsworth, C.M., Tyler, T.J., and VanderKooi, S.P., (in press), Using spatial, seasonal, and diel drift patterns of larval Lost River suckers Deltistes luxatus (Cypriniformes: Catostomidae) and shortnose suckers Chasmistes brevirostris (Cypriniformes: Catostomidae) to help identify a site for a water withdrawal structure on the Williamson River, Oregon: Environmental Biology of Fishes.

Elseroad, A., Nathan R., Hendrixson, H., 2010, Williamson River Delta Preserve vegetation monitoring: Goose Bay first-year post-breaching results: The Nature Conservancy, Oregon, 10 p.

Erdman, C.S., and Hendrixson, H.A., 2009, Larval shortnose and Lost River sucker response to large scale wetland restoration of the north half of the Williamson River Delta Preserve, Oregon: The Nature Conservancy, Oregon.

Hendrixson, H.A., 2008, Non-native fish species and Lost River and shortnose suckers use of restoration and undisturbed wetlands at the Williamson River Delta: Final report of activities conducted in 2006 and 2007: Report of The Nature Conservancy to the U.S. Fish and Wildlife Service, Klamath Falls, Oregon, 28 p.

Hoff, G.R., Logan, D.J., and Markle, D.F., 1997, Otolith morphology and increment validation in young Lost River and shortnose suckers: Transactions of the American Fisheries Society, v. 126, p. 488-494. Kelso, W.E., and Rutherford, D.A., 1996, Collection, preservation, and identification of fish eggs and larvae in Murry, B.R., and Willis, D.W., eds., Fisheries Techniques, 2nd edition: American Fisheries Society, Bethesda, Maryland, p. 255-302.

Koch, J.D., Schreck, W.J., and Quist, M.C., 2008, Standardized removal and sectioning locations for shovelnose sturgeon fin rays: Fisheries Management and Ecology, v. 15, p. 139-145. 
Lane, J.A., Portt, C.B., and Minns, C.K., 1996, Spawning habitat characteristics of Great Lakes fishes: Canadian Manuscript Report of Fisheries and Aquatic Sciences, v. 2368, 48 p.

Markle, D.F., Reithel, S.A., Crandall, J., Wood, T., Tyler, T., Terwilliger, M., and Simon, D.C., 2009, Larval fish transport and retention and the importance of location for juvenile fish recruitment in Upper Klamath Lake, Oregon: Transactions of the American Fisheries Society, v. 138, p. 328-347, doi: 10.1577/T07-274.1, accessed August 13, 2010, at http://afsjournals.org/doi/abs/10.1577/T07-274.1.

Remple, S., and Markle, D.F., 2005, Description and identification of larval and juvenile cyprinids (fathead minnow, tui chub, and blue chub) from Upper Klamath Lake, Oregon: California Fish and Game, v. 91, no. 2, p. 83-99.

Wood, T.M., 2009, Preliminary study of the effect of the proposed Long Lake Valley project operation on the transport of larval suckers in Upper Klamath Lake, Oregon: U.S. Geological Survey Open-File Report 2009-1060, 24 p. (Also available at http://pubs.usgs.gov/of/2009/1060/.) 


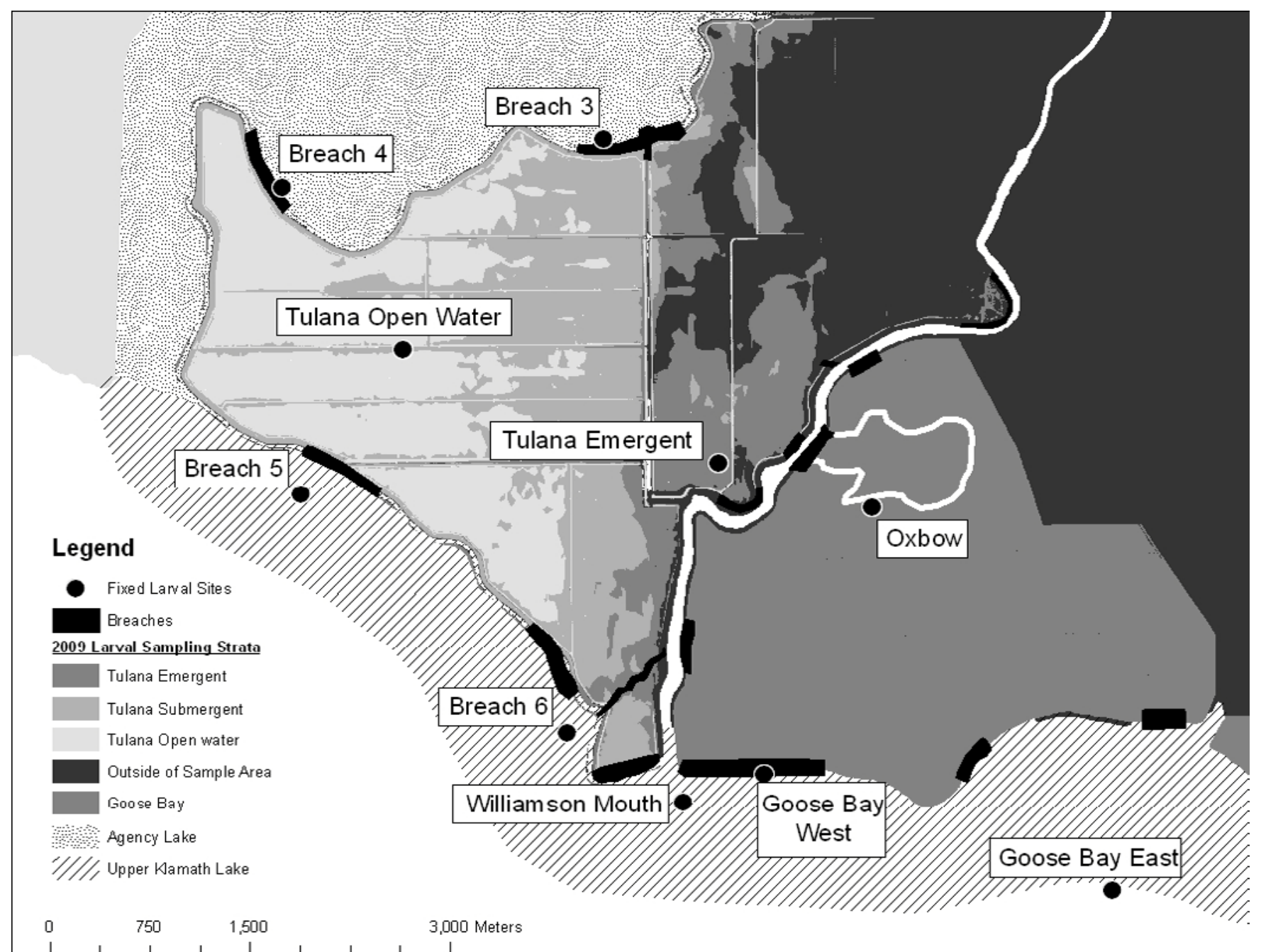

Figure 2.1. Larval fish sampling locations in and adjacent to the Williamson River Delta, Oregon. Fixed sampling sites, which were visited once weekly, were selected to capture larval suckers as they were passively transported across the delta by water currents. In addition, approximately even numbers of sites were randomly selected from each larval sampling stratum to capture variation in habitat use across the delta by larval endangered suckers. Map layers for vegetation types were provided courtesy of The Nature Conservancy. The locations of excavated dikes (breaches), which were removed to let water into the delta also are shown. Coordinate information is referenced to the Western Geographic System of 1984 (WGS84). 

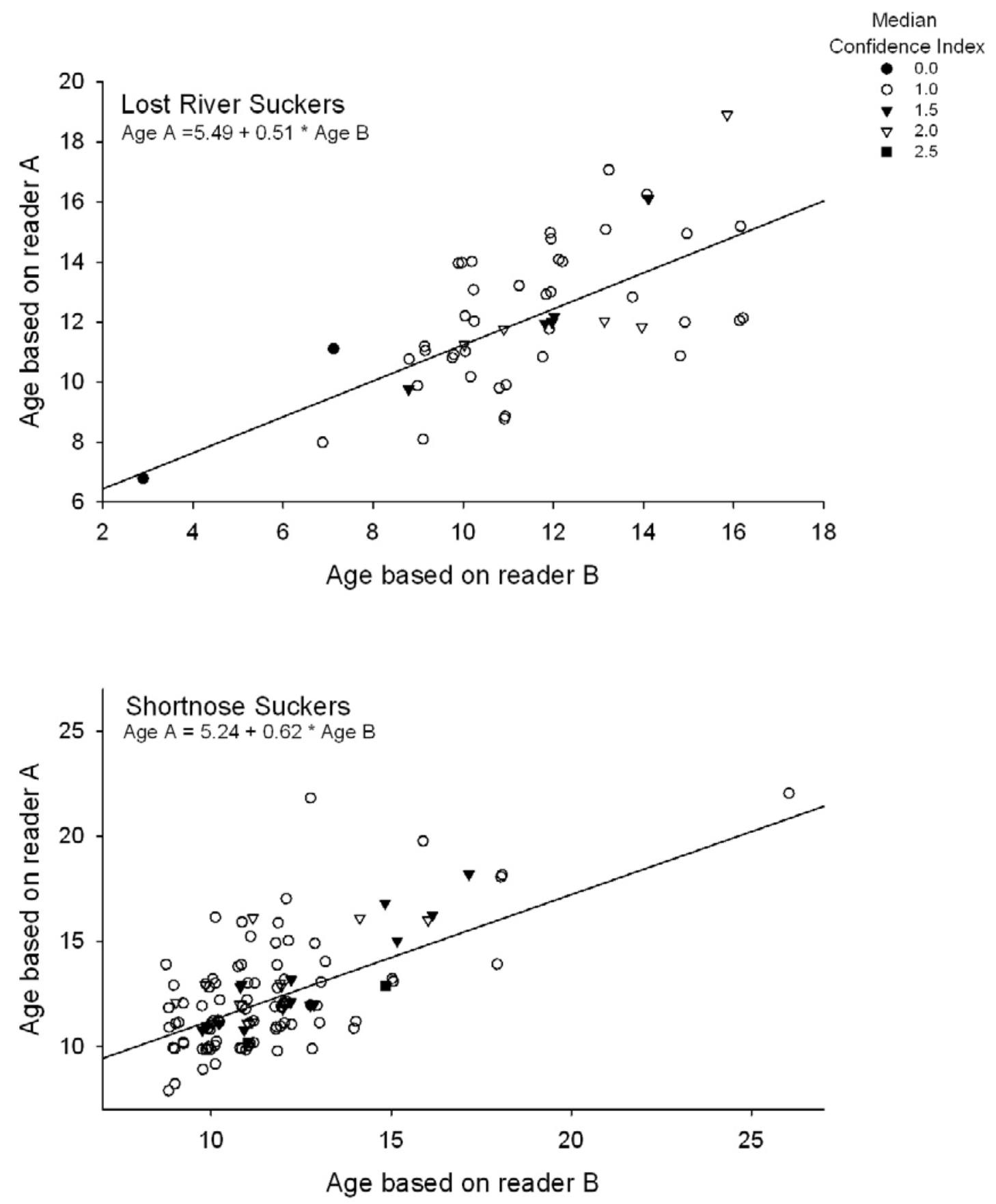

Figure 2.2. Comparison of larval Lost River and shortnose or Klamath largescale suckers . Sucker ages estimated by two readers that read the same lapilli otoliths. Symbols indicate the median confidence index calculated for the two readers, which is on a scale from 0 (no confidence) to 3 (total confidence) (Koch and others, 2008). Points were randomly jittered to improve the display. Lines and equations illustrate the relations between estimated ages by the two readers ( $R^{2}=0.31$ for Lost River suckers and $R^{2}=0.35$ for shortnose suckers). Regression analysis was performed without the obvious outliers. 

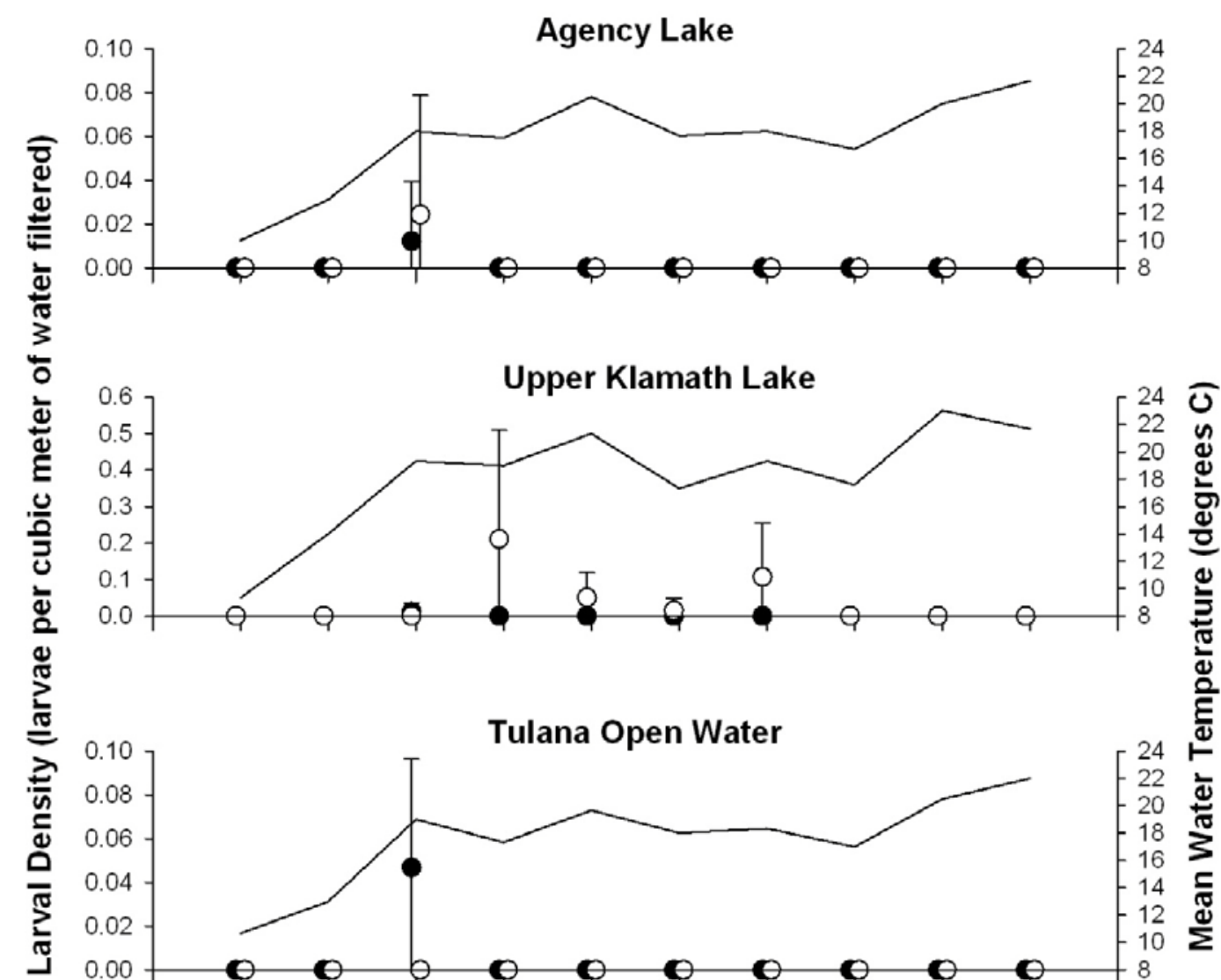

Figure 2.3. Mean ( \pm SD) weekly sample density for Lost River sucker larvae (black dots), and a grouping of larvae identified as either shortnose or Klamath largescale suckers (gray dots). Mean water temperature for larval tow sites is shown with black lines. Larvae were collected in plankton nets towed in five sample strata (see fig. 2.1) in and around the Williamson River Delta, Oregon, between May 4 and July 8, 2009. We did not catch suckers in one of the strata (Tulana Submergent), therefore it is not shown here. Note the difference in scale along the y-axes. 


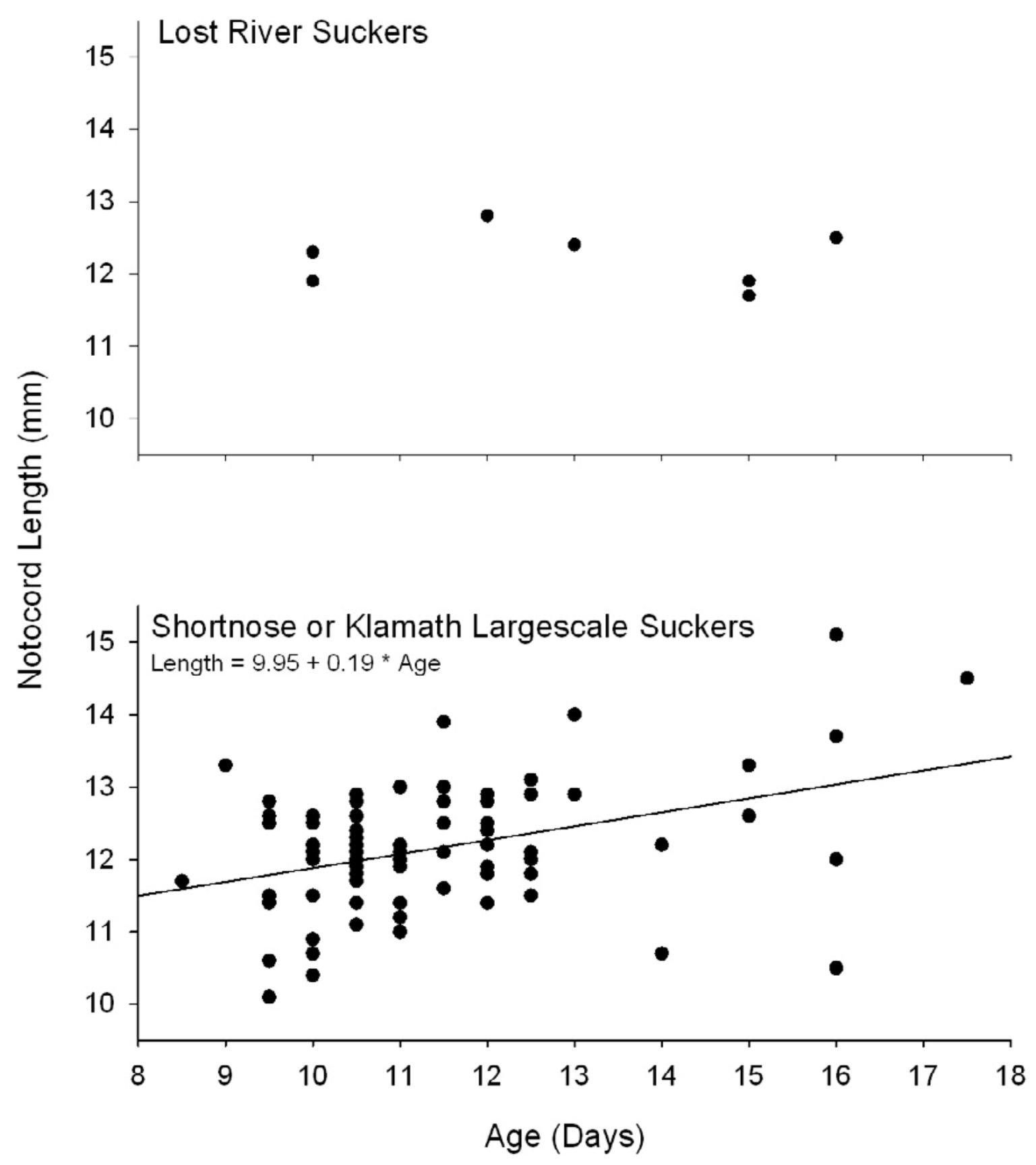

Figure 2.4. Length to age comparison for Lost River and shortnose or Klamath largescale sucker larvae captured during our random stratified sampling in and adjacent to the Williamson River Delta. Age estimates were based on median lapilli otolith ring counts by at least two independent readers. The linear relation between length and age data for shortnose suckers is illustrated by the line and regression equation $\left(R^{2}=0.11\right)$. Linear regression was not performed for Lost River suckers due to sparse data. 


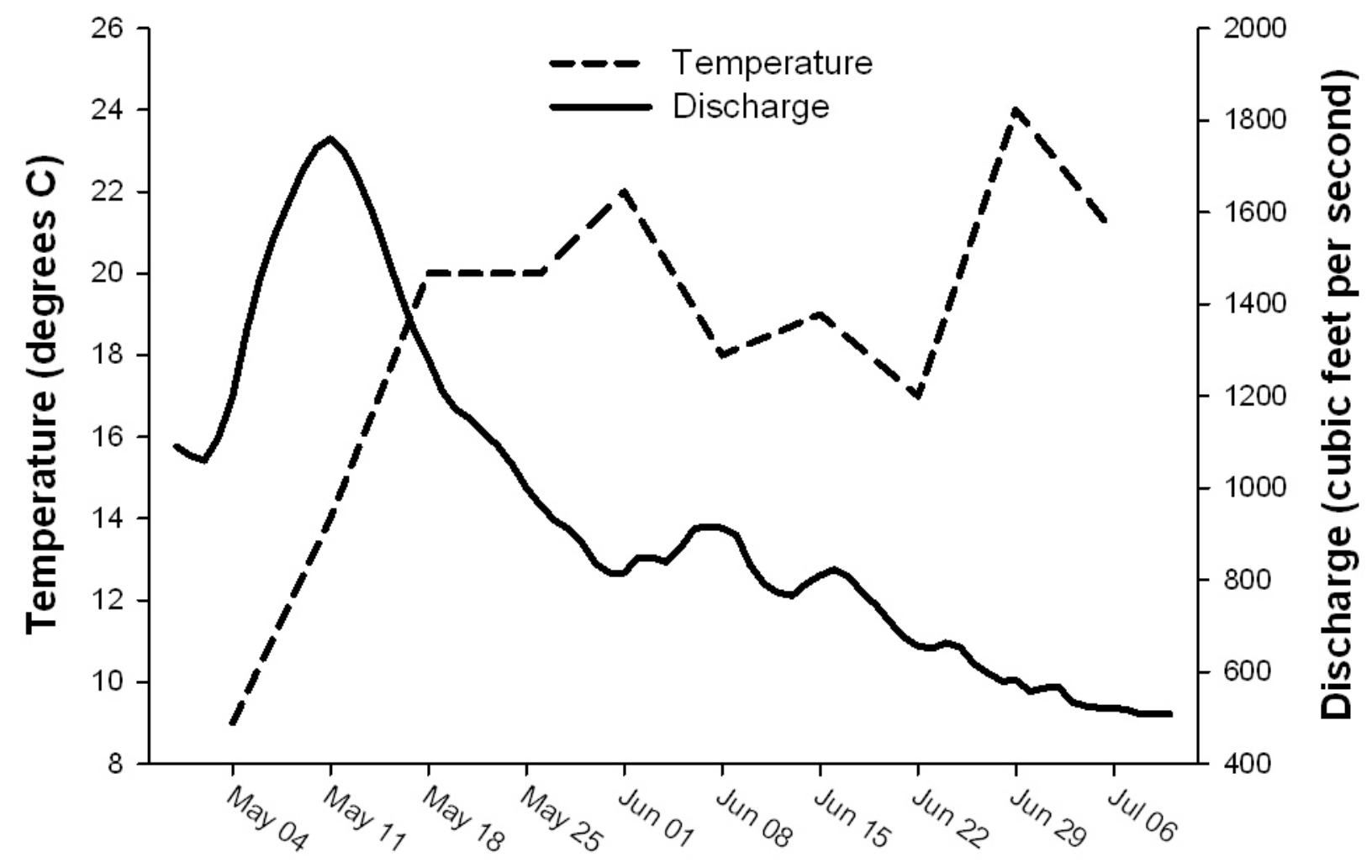

Figure 2.5. Williamson River discharge [cubic feet per second, solid line; U.S. Geological Survey, 2009; gaging station No. 11502500] and water temperature at the mouth of the Williamson River (dashed line), as measured during weekly site visits between May 4 and July 8, 2009. Ten sites were visited weekly to sample for larval fish. 

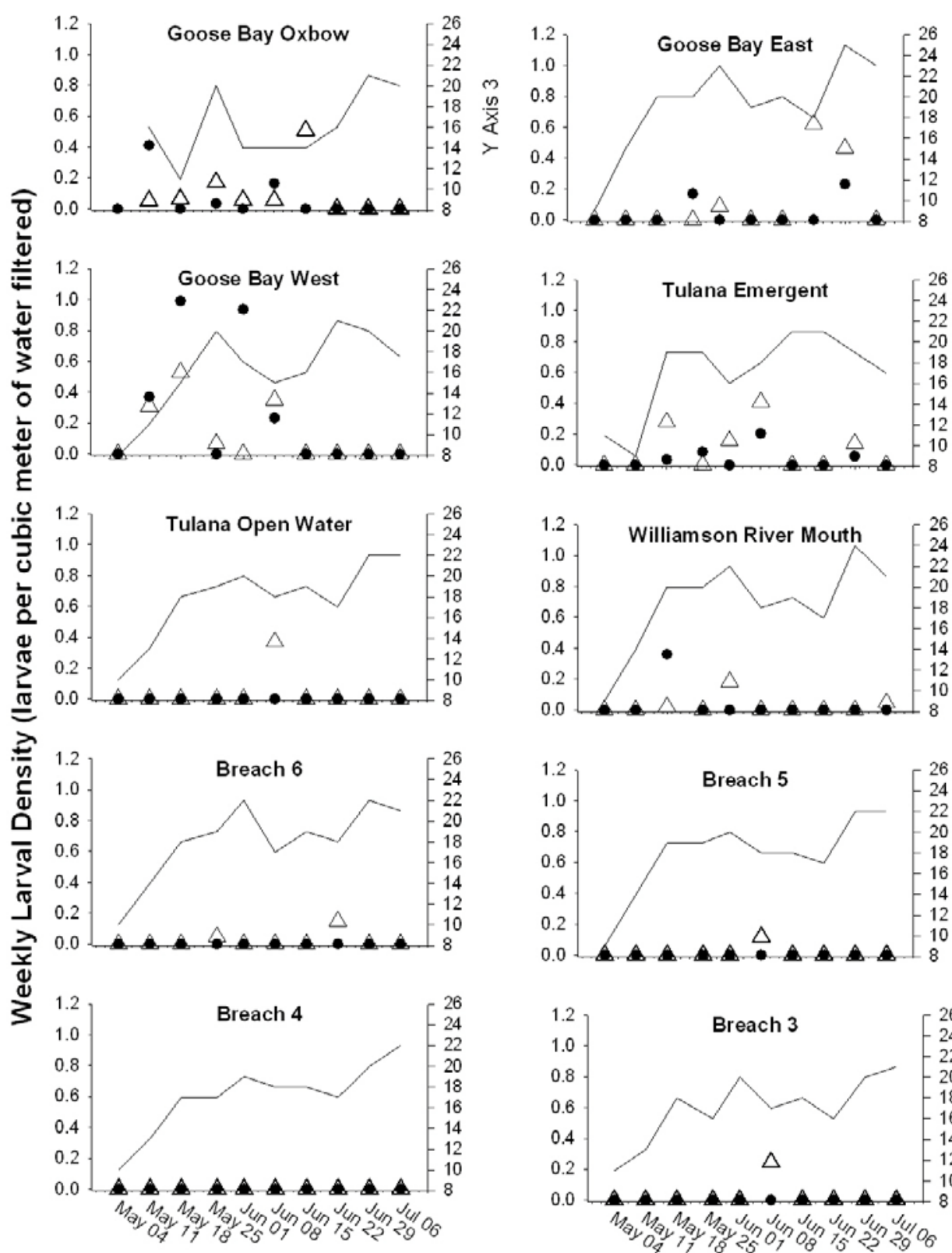

(3)
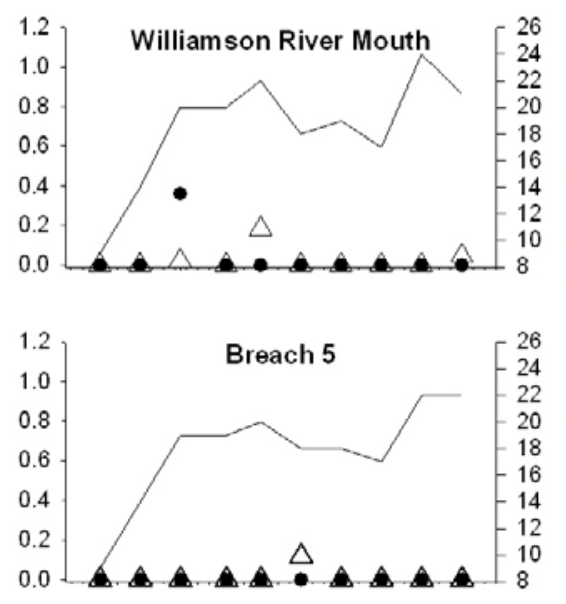

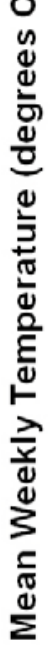

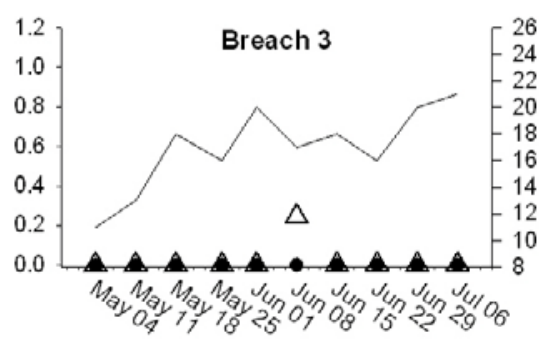

Figure 2.6. Larval Lost River (black dots) and the group of larvae identified as either shortnose or Klamath largescale (open triangles) sucker sample densities at 10 fixed sites sampled weekly in and adjacent to the Williamson River Delta, Oregon, between May 4 and July 8, 2009. Larvae were collected in plankton nets towed laterally to a boat at slow speeds. Solid lines indicate water temperatures recorded at the time of sampling. 


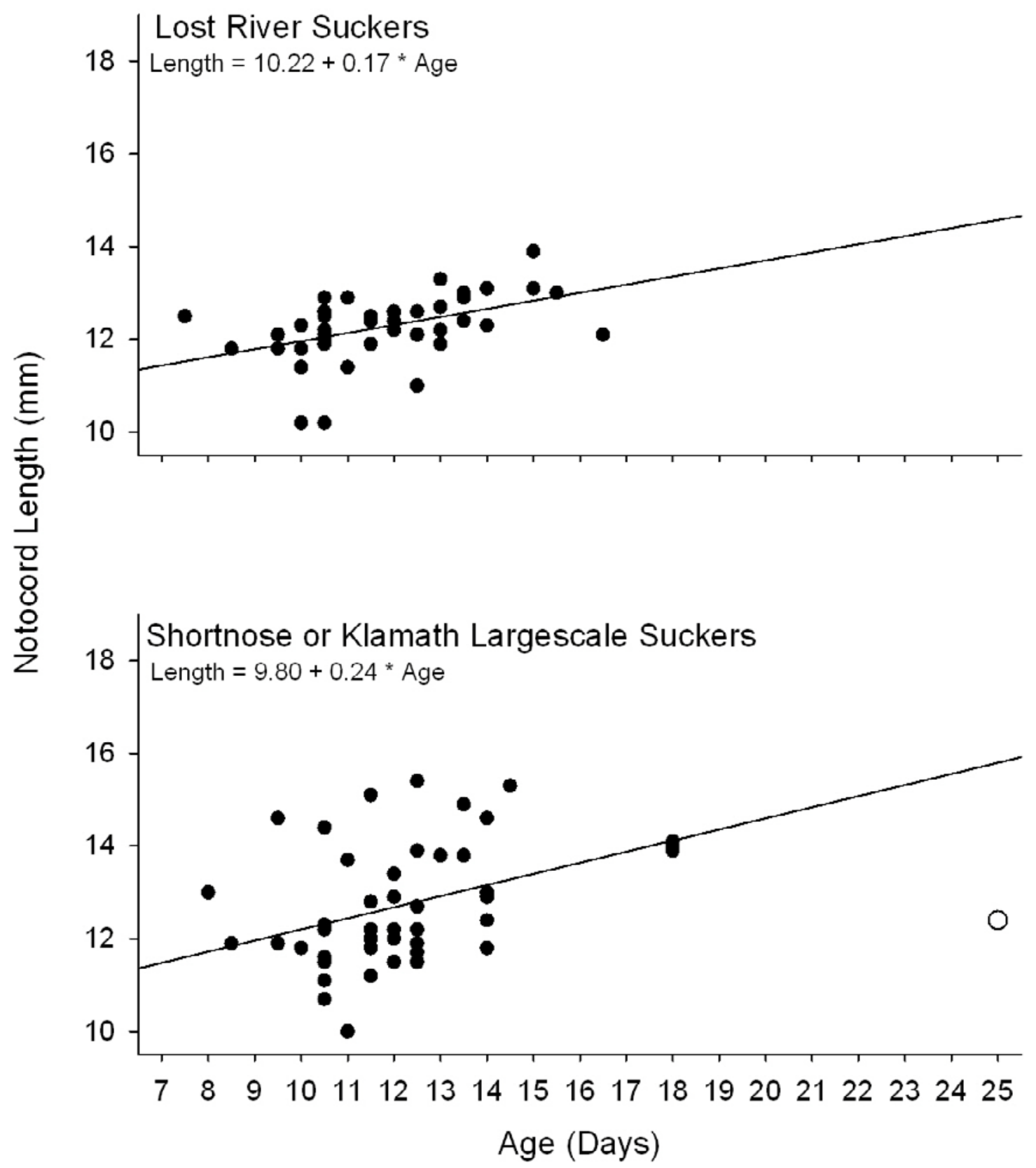

Figure 2.7. Length to age comparison for Lost River and shortnose or Klamath largescale sucker larvae captured during our fixed site sampling in and adjacent to the Williamson River Delta. Age estimates were based on median lapilli otolith ring counts by at least two independent readers. The linear relation between length and age data for Lost River suckers $\left(R^{2}=0.21\right)$ and shortnose suckers $\left(R^{2}=0.15\right)$ is illustrated by the line and regression equation. Regression analysis was performed for shortnose or Klamath largescale sucker larvae without the obvious outlier (open circle). 


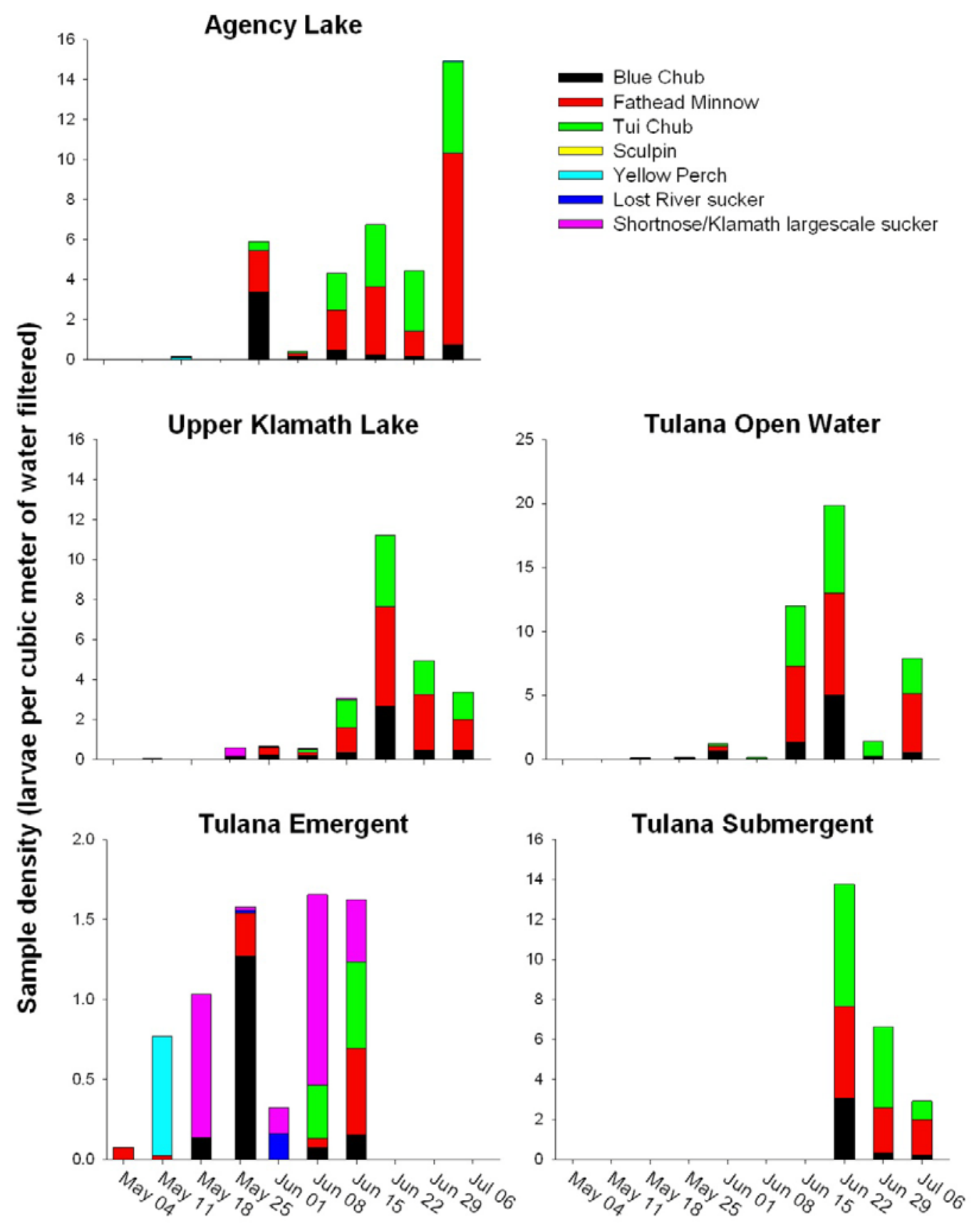

Figure 2.8. Mean weekly sample density of larval fish in plankton samples collected from five strata (fig. 2.1) during our random stratified sampling in and adjacent to the Williamson River Delta, Oregon, between May 4 and July 8 , 2009. The scale of the $y$-axis varies among panels to better illustrate the species composition in each stratum. 


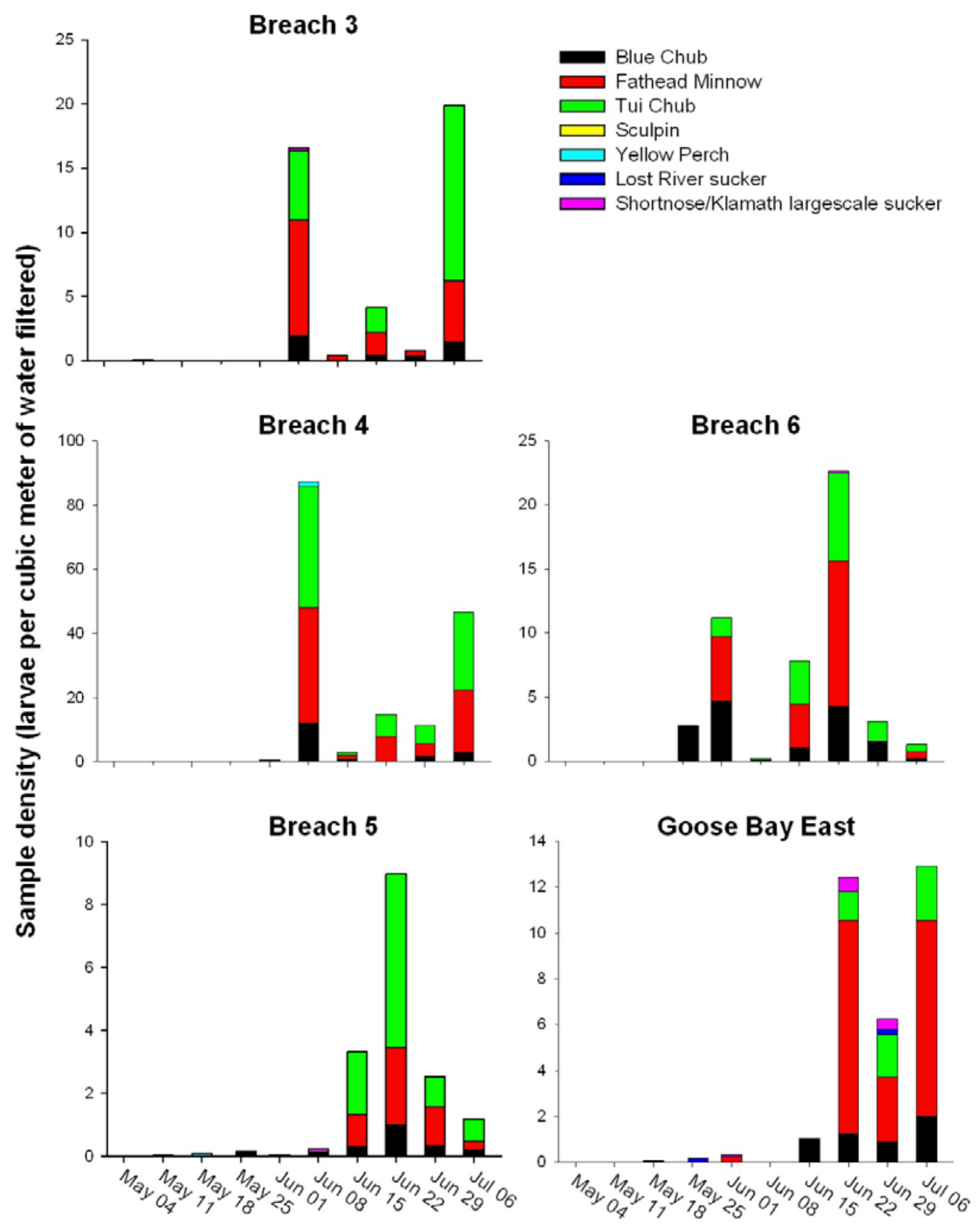

Figure 2.9. Larval sample density (larvae per cubic meter of water filtered) by week and species at 10 fixed sites sampled weekly in and adjacent to the Williamson River Delta, Oregon, between May 4 and July 8, 2009. The scale of the $y$-axis varies among panels to better illustrate the species composition at each site. 


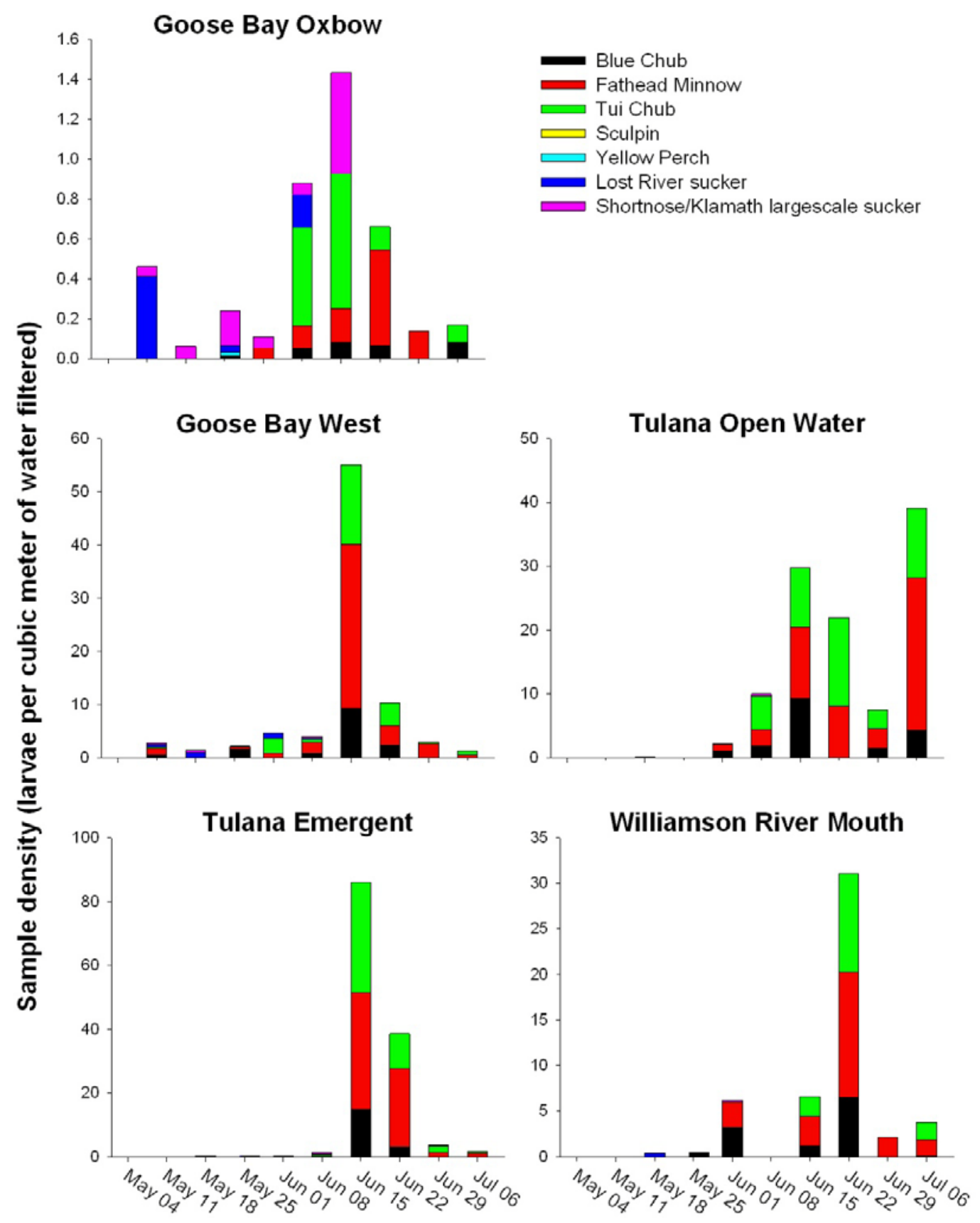

Figure 2.9 Continued. 
Table 2.1 Number of visits and mean site depth at each fixed plankton sample location in and adjacent to the Williamson River Delta, Oregon.

[*Not all depths were measured and had to be estimated from gage height and measured depths. See figure 2.1 for location of sampling strata. Depths were measured during each weekly sampling occasion, which occurred between May 4 and July 8 , 2009. SD, standard deviation; ft, feet]

\begin{tabular}{llll}
\hline Strata & $\begin{array}{l}\text { Number } \\
\text { of visits }\end{array}$ & $\begin{array}{l}\text { Mean depth } \\
\text { (ft) }\end{array}$ & $\mathbf{\pm ~ S D ~}$ \\
\hline Goose Bay East & 10 & 2 & 0.19 \\
Goose Bay West & 10 & $2.1^{*}$ & 0.03 \\
Goose Bay Oxbow & 9 & $1.4^{*}$ & 0.03 \\
Tulana Emergent & 10 & $1.1^{*}$ & 0.03 \\
Tulana Open Water & 10 & 1.8 & 0.16 \\
Williamson Mouth & 10 & 2.7 & 0.19 \\
Breach 3 & 10 & 2.9 & 0.09 \\
Breach 4 & 10 & 1.1 & 0.41 \\
Breach 5 & 10 & 2 & 0.13 \\
Breach 6 & 10 & 2 & 0.25 \\
\hline
\end{tabular}


Table 2.2 Mean sample density for Lost River and shortnose/Klamath largescale sucker larvae in random stratified plankton sampling conducted in five strata in and adjacent to the Williamson River Delta, Oregon.

\begin{tabular}{lccccc}
\hline & & \multicolumn{4}{c}{ Sample density } \\
\cline { 3 - 6 } \multicolumn{1}{c}{ Strata } & $\begin{array}{c}\text { Number of } \\
\text { samples }\end{array}$ & \multicolumn{2}{c}{ Lost River } & \multicolumn{2}{c}{$\begin{array}{c}\text { Shortnose or Klamath } \\
\text { largescale }\end{array}$} \\
\cline { 3 - 6 } & & Mean & $\mathbf{\pm ~ S D}$ & Mean & $\mathbf{\pm}$ SD \\
\hline Agency Lake & 22 & 0.003 & 0.000 & 0.005 & 0.000 \\
Upper Klamath Lake & 26 & 0.002 & 0.000 & 0.049 & 0.015 \\
Tulana Open Water & 22 & 0.001 & 0.000 & 0.000 & 0.000 \\
Tulana Emergent & 8 & 0.030 & 0.002 & 0.784 & 0.167 \\
Tulana Submergent & 4 & 0.000 & 0.000 & 0.000 & 0.000 \\
\hline Total & 82 & 0.007 & 0.000 & 0.093 & 0.002
\end{tabular}

Table 2.3 Percentage of larval Lost River suckers caught in plankton nets during random stratified sampling, with 0 , $25,50,75$, or 100 percent of their guts full of food in five sampling strata in and adjacent to the Williamson River Delta, Oregon.

\begin{tabular}{lcccccc}
\hline & \multicolumn{7}{c}{ Percent Gut Fullness } \\
\cline { 2 - 7 } \multicolumn{1}{c}{ Strata } & $\mathbf{n}$ & $\mathbf{0}$ & $\mathbf{2 5}$ & $\mathbf{5 0}$ & $\mathbf{7 5}$ & $\mathbf{1 0 0}$ \\
\hline Agency Lake & 1 & 100 & 0 & 0 & 0 & 0 \\
Upper Klamath Lake & 1 & 0 & 100 & 0 & 0 & 0 \\
Tulana Open Water & 4 & 50 & 50 & 0 & 0 & 0 \\
Tulana Emergent & 2 & 50 & 0 & 50 & 0 & 0 \\
Tulana Submergent & 0 & 0 & 0 & 0 & 0 & 0 \\
\hline Total & 8 & 50 & 38 & 13 & 0 & 0
\end{tabular}

Table 2.4 Percentage of larvae identified as either Klamath largescale or shortnose suckers caught in plankton nets during random stratified sampling, with $0,25,50,75$, or 100 percent of their guts full of food from five sampling strata in and adjacent to the Williamson River Delta, Oregon.

\begin{tabular}{lcccccc}
\hline & \multicolumn{7}{c}{ Percent gut fullness } \\
\cline { 2 - 7 } \multicolumn{1}{c}{ Strata } & $\mathbf{n}$ & $\mathbf{0}$ & $\mathbf{2 5}$ & $\mathbf{5 0}$ & $\mathbf{7 5}$ & $\mathbf{1 0 0}$ \\
\hline Agency Lake & 2 & 50 & 50 & 0 & 0 & 0 \\
Upper Klamath Lake & 12 & 25 & 25 & 17 & 8 & 25 \\
Tulana Open Water & 0 & 0 & 0 & 0 & 0 & 0 \\
Tulana Emergent & 80 & 20 & 57 & 14 & 5 & 4 \\
Tulana Submergent & 0 & 0 & 0 & 0 & 0 & 0 \\
\hline Total & 94 & 21 & 53 & 14 & 5 & 7
\end{tabular}


Table 2.5 Percentage of larval Lost River suckers caught in plankton nets during fixed site sampling, with $0,25,50$, 75 , or 100 percent of their guts full of food at 10 sites in and adjacent to the Williamson River Delta, Oregon.

\begin{tabular}{lcccccc}
\hline & \multicolumn{7}{c}{ Percent gut fullness } \\
\cline { 2 - 7 } \multicolumn{1}{c}{ Strata } & $\mathbf{n}$ & $\mathbf{0}$ & $\mathbf{2 5}$ & $\mathbf{5 0}$ & $\mathbf{7 5}$ & $\mathbf{1 0 0}$ \\
\hline Goose Bay Oxbow & 13 & 8 & 46 & 31 & 15 & 0 \\
Goose Bay East & 4 & 0 & 75 & 25 & 0 & 0 \\
Goose Bay West & 24 & 59 & 25 & 8 & 8 & 0 \\
Tulana Emergent & 6 & 0 & 17 & 83 & 0 & 0 \\
Tulana Open Water & 0 & 0 & 0 & 0 & 0 & 0 \\
Williamson Mouth & 19 & 11 & 32 & 32 & 16 & 11 \\
Breach 3 & 0 & 0 & 0 & 0 & 0 & 0 \\
Breach 4 & 0 & 0 & 0 & 0 & 0 & 0 \\
Breach 5 & 0 & 0 & 0 & 0 & 0 & 0 \\
Breach 6 & 0 & 0 & 0 & 0 & 0 & 0 \\
\hline Total & 66 & 26 & 33 & 27 & 11 & 3
\end{tabular}

Table 2.6 Percentage of larvae identified as either Klamath largescale or shortnose suckers caught in plankton nets during fixed site sampling, with $0,25,50,75$, or 100 percent of their guts full of food at 10 sites in and adjacent to the Williamson River Delta, Oregon.

\begin{tabular}{lcccccc}
\hline & \multicolumn{7}{c}{ Percent gut fullness } \\
\cline { 2 - 7 } \multicolumn{1}{c}{ Strata } & $\mathbf{n}$ & $\mathbf{0}$ & $\mathbf{2 5}$ & $\mathbf{5 0}$ & $\mathbf{7 5}$ & $\mathbf{1 0 0}$ \\
\hline Goose Bay Oxbow & 20 & 15 & 35 & 15 & 25 & 10 \\
Goose Bay East & 6 & 0 & 17 & 33 & 17 & 33 \\
Goose Bay West & 17 & 53 & 29 & 6 & 12 & 0 \\
Tulana Emergent & 19 & 11 & 53 & 26 & 5 & 5 \\
Tulana Open Water & 1 & 0 & 100 & 0 & 0 & 0 \\
Williamson Mouth & 3 & 0 & 67 & 0 & 33 & 10 \\
Breach 3 & 1 & 0 & 100 & 0 & 0 & 0 \\
Breach 4 & 0 & 0 & 0 & 0 & 0 & 0 \\
Breach 5 & 1 & 0 & 100 & 0 & 0 & 0 \\
Breach 6 & 2 & 0 & 50 & 0 & 0 & 50 \\
\hline Total & 70 & 20 & 40 & 16 & 14 & 10
\end{tabular}


Table 2.7 Mean notochord length for larval Lost River suckers and larvae identified as either shortnose or Klamath largescale suckers, collected at each of ten fixed sampling sites in and adjacent to the Williamson River Delta, Oregon.

[See figure 2.1 for location of sampling strata. Each site was sampled weekly between May 4 and July 8, 2009. The numbers of larvae measured (n) throughout the sampling season are given for each site. SD, standard deviation; mm, millimeter]

\begin{tabular}{lcccc}
\hline \multicolumn{1}{c}{ Strata } & $\mathbf{n}$ & $\begin{array}{c}\text { Lost River } \\
\text { mean } \mathbf{\pm} \text { SD } \\
(\mathbf{m m})\end{array}$ & $\mathbf{n}$ & $\begin{array}{c}\text { Shortnose or Klamath } \\
\text { largescale } \\
\text { mean } \mathbf{\pm} \text { SD } \\
(\mathbf{m m})\end{array}$ \\
\hline Goose Bay Oxbow & 13 & $11.9 \pm 0.7$ & 20 & $13.2 \pm 1.3$ \\
Goose Bay East & 4 & $12.8 \pm 0.4$ & 6 & $13.3 \pm 2.4$ \\
Goose Bay West & 24 & $12.0 \pm 1.0$ & 17 & $12.0 \pm 1.2$ \\
Tulana Emergent & 6 & $11.5 \pm 1.5$ & 19 & $11.9 \pm 0.9$ \\
Tulana Open Water & 0 & 0 & 1 & $12.0 \pm 0.0$ \\
Williamson Mouth & 19 & $12.6 \pm 0.4$ & 3 & $13.6 \pm 1.7$ \\
Breach 3 & 0 & 0 & 1 & $11.9 \pm 0.0$ \\
Breach 4 & 0 & 0 & 0 & 0 \\
Breach 5 & 0 & 0 & 1 & $12.0 \pm 0.0$ \\
Breach 6 & 0 & 0 & 2 & $12.7 \pm 1.8$ \\
\hline Total & 66 & $12.17 \pm 0.8$ & 70 & $12.59 \pm 1.7$
\end{tabular}

Table 2.8 Length to age ratios for larval Lost River suckers and larvae identified as either shortnose or Klamath largescale suckers, collected at each of ten fixed sampling sites in and adjacent to the Williamson River Delta, Oregon.

\begin{tabular}{|c|c|c|c|c|}
\hline \multirow[b]{2}{*}{ Strata } & \multicolumn{2}{|c|}{ Lost River } & \multicolumn{2}{|c|}{$\begin{array}{l}\text { Shortnose/Klamath } \\
\text { largescale }\end{array}$} \\
\hline & $\mathrm{n}$ & $\begin{array}{l}\text { mean } \pm S D \\
(\mathrm{~mm} / \text { days })\end{array}$ & $\mathrm{n}$ & $\begin{array}{l}\text { mean } \pm S D \\
\text { (mm/days) }\end{array}$ \\
\hline Goose Bay East & 3 & $1.01 \pm 0.16$ & 4 & $1.15 \pm 0.32$ \\
\hline Goose Bay West & 7 & $1.15 \pm 0.19$ & 9 & $1.04 \pm 0.15$ \\
\hline Goose Bay Oxbow & 12 & $1.14 \pm 0.24$ & 18 & $1.06 \pm 0.21$ \\
\hline Tulana Emergent & 4 & $0.99 \pm 0.12$ & 12 & $1.08 \pm 0.14$ \\
\hline Tulana Open Water & 0 & 0 & 1 & $1.04 \pm 0.00$ \\
\hline Williamson Mouth & 16 & $1.05 \pm 1.20$ & 3 & $0.88 \pm 0.17$ \\
\hline Breach 3 & 0 & 0 & 0 & 0 \\
\hline Breach 4 & 0 & 0 & 0 & 0 \\
\hline Breach 5 & 0 & 0 & 0 & 0 \\
\hline Breach 6 & 0 & 0 & 0 & 0 \\
\hline Total & 42 & $1.09 \pm 1.94$ & 47 & $1.04 \pm 1.03$ \\
\hline
\end{tabular}




\section{Chapter 3-Juvenile Fish Retention and Distribution}

\section{Introduction and Background}

One of the primary goals of the Williamson River Delta restoration project was to create highquality nursery habitat for endangered suckers. When wetland habitats, such as those recreated in the Williamson River Delta, are present and functional, they support increased density, survival, and growth of juvenile fish and ultimately increased abundance in adult populations (Beck and others, 2001). Vegetation on the eastern side of the Williamson River Delta may provide habitat for age- 0 suckers, and unvegetated, deep water environments may provide habitat for older juveniles (Burdick and others, 2009b).

Restoration in the Williamson River Delta may have created rearing habitat for other fish. Some of these species are piscivorous and may prey on suckers while others are not. To be a threat to larval and juvenile suckers, piscivorous fish must be large enough to consume their prey during times of cooccupancy. Piscivorous species detected in the Tulana Unit of the Williamson River Delta in 2008 include fathead minnows (Pimephales promelas) that prey on larval suckers (Markle and Dunsmoor, 2007), yellow perch (Perca flavescens), largemouth bass (Micropterus salmoides), and redband trout (Oncorhynchus mykiss newberri) (Burdick and others, 2009b).

Several native and non-native fishes also began to occupy habitats within the Williamson River Delta after flooding of the Tulana Unit in 2007. Non-native and primarily non-piscivorous fishes detected in 2008 included brown bullhead (Ameiurus nebulosus) that eat insects, and pumpkinseed (Lepomis gibbosus) that eat insects and mollusks. Common native species caught in the Williamson River Delta in 2008 include the lake-dwelling omnivorous tui chub (Gila bicolor) and blue chub (Gila coerulea), a species that is most likely a subspecies of the parasitic Pacific lamprey (Lampetra tridentate), and the primarily stream-dwelling speckled dace (Rhinichthys osculus) (Burdick and others, 2009b). Three sculpin species endemic to the Upper Klamath Basin also were captured in the delta during 2008 Klamath Lake sculpin (Cottus princeps), Upper Klamath marbled sculpin (Cottus klamathensis klamathensis), and slender sculpin (Cottus tenuis).

We summarized data in this chapter to meet four short-term goals, which are a subset of the overall project objectives (see report introduction).

- Goal 1: Describe the spatial and temporal use of available environments within the restored Williamson River Delta and southern Agency Lake by juvenile suckers in 2009.

- Goal 2: Compare condition, frequency of parasites, and deformities for juvenile suckers caught in the Williamson River Delta restoration area to those captured in open-water, near-shore, and offshore environments in southern Agency Lake in 2009.

- Goal 3: Compare juvenile fish community structure in the restored Williamson River Delta to established open-water, near-shore, and off-shore environments in southern Agency Lake in 2009.

- Goal 4: Examine the use of the Williamson River Delta by piscivorous fishes that may pose a threat to larval or juvenile endangered suckers. 


\section{Methods}

\section{Juvenile Fish Sampling}

We used a random stratified sampling approach to evaluate restoration of the Williamson River Delta and the southern part of Agency Lake. Sampling effort and data collection were designed to meet the requirements for an occupancy analysis that allows for quantitative estimation of detection and occupancy probabilities for rare species, such as suckers. An approximately equal number of sites were randomly selected from each of six strata: Agency Near-Shore, Agency Off-Shore, Tulana Open Water, Tulana Submergent, Tulana Emergent, and Goose Bay (see introduction fig. 1.2; table 3.1). Sampling in and near the Williamson River Delta coincided with sampling throughout Upper Klamath Lake that was conducted under agreement 07AA200135 with the Bureau of Reclamation.

Juvenile fish were sampled with rectangular trap nets with mouth dimensions of $0.609 \times 0.914$ $\mathrm{m}$, a $10-\mathrm{m}$ lead, and three internal fykes. These nets had 6.4-mm mesh, green nylon netting. Hereafter, these nets are referred to as small trap nets. At each site, we set three small trap nets in a circular pattern with the mouth openings arranged approximately $120^{\circ}$ to each other to avoid interference among nets. Nets were set between 1044 and 1953 hours each day and pulled the next day between 0748 and 1810 hours for a target soak time of 20 hours for each net set. Net set and pull times as well as depth at the end of the lead net and the net mouth were recorded for each net. Lead line and mouth depths for all three nets at each site were averaged for a single measure of depth. At sites less than $3 \mathrm{~m}$, we probed the bottom of the lake with a PVC pole to ascertain substrate composition as best as possible. The percentage of each $2,500-\mathrm{m}^{2}$ site covered with vegetation and the portion of plants in each genus within a random $1-\mathrm{m}^{2}$ sample at each site also was recorded.

We designated three sampling periods that we refer to throughout this report as seasons. We classified spring as the period from May 4 to June 19, mid-summer as the period from June 22 to July 31 , and late summer as the period from August 3 to September 18. These designations were designed to coincide with the presence of age- 1 and older juvenile suckers in spring, the peak of age-0 sucker abundance in mid-summer, and the decrease of age- 0 sucker abundance in late summer. We delineated these time periods based on historical catch data for age- 0 and age-1 suckers (VanderKooi and others, 2006; Hendrixson and others, 2007; Burdick and others, 2008b; Burdick and others, 2009a). Our goal was to sample 300 sites split among all six strata once during each season, however, low water levels prevented us from sampling shallow sites in the mid-summer and late-summer periods. Therefore, we sampled more shallow water sites than deep water sites during spring and more deep water sites than shallow water sites during late summer.

Fish were identified to species or the lowest practical taxa and counted. For suckers, standard length was measured and the presence of deformities and macroparasites were noted. When the weight of the catch exceeded $3 \mathrm{~kg}$, the total number of individuals of non-suckers was estimated by extrapolation using the ratio of subsample weight to total weight. Species composition was assumed to be representative of total catch. Subsamples were taken by placing the entire sample in a $0.07 \mathrm{~m}^{3}$ large water-filled tub, thoroughly mixing contents, and removing approximately 30 percent of the original sample weight using a dip net. Presence or absence of each species in the remaining 70 percent was recorded in four classes: tiny $<40 \mathrm{~mm}$, small $40-100 \mathrm{~mm}$, medium 100-200 mm, and large $\geq 200 \mathrm{~mm}$. 
About one-third of the suckers less than $70 \mathrm{~mm}$ and one-tenth of the suckers between 70 and 145 $\mathrm{mm}$ were sacrificed and preserved in 95-percent denatured ethanol for later identification. In the laboratory, we identified juvenile suckers to the species level following Markle and others (2005) using a combination of techniques that included vertebrae enumeration, lip morphology, and gill raker counts. The number of each sucker species in a catch was estimated by multiplying the species proportion in the subsample of sacrificed fish by the total number of juvenile suckers caught. We classified suckers as age- 0 , age-1, or older based on weekly length frequency plots.

Suckers were PIT (passive integrated transponder)-tagged to understand movement patterns in relation to environmental variables and to validate age estimates. To increase the number of suckers we were able to tag, we conducted 16 additional net sets on April 15, 2009. Healthy suckers $70 \mathrm{~mm}$ or longer collected during spring sampling were injected with full duplex PIT tags that were cylindrical, $12.45 \mathrm{~mm}$ in length, $2.02 \mathrm{~mm}$ in diameter, weighed $0.106 \mathrm{~g}$, and operated at a frequency of $134.2 \mathrm{kHz}$. These tags can be remotely detected and do not cause significant mortality in juvenile suckers (Burdick and VanderKooi, 2010). Prior to tagging, suckers were scanned for the presence of PIT tags and anesthetized in a solution of MS-222 prepared with lake water. The concentration of this solution ranged between 0.02 and $0.03 \mathrm{mg} / \mathrm{L}$ depending on the size and reaction of each fish. Suckers remained in the solution until they did not respond to stimulus (probing with net or stick). Taggers were trained using preserved specimens prior to tagging live fish. Between injections, needles were sterilized with a 3 percent solution of chlorhexidine. Wounds were not closed with sutures and no antibiotics were administered, because post-tagging survival is high without these added precautions (Burdick and VanderKooi, 2010).

PIT tags could be detected in one of three ways; manually scanning subsequently captured suckers, surveys at piscivorous bird colonies, or on remote underwater PIT tag detection systems. American white pelican (Pelecanus erythrorhynchos) and double-crested cormorant (Phalacrocorax auritus) colonies located in the Upper Klamath, Lower Klamath, and Clear Lake Wildlife refuges, were scanned for tags using handheld detection wands during the week of October 26, 2009. Bird Research Northwest sampled the majority of nesting sites for these species in each of the three refuges and is in the process of estimating detection probabilities for each site. Locations of fixed detection arrays were upstream and downstream traps on the Williamson River fish weir, a river-wide array immediately upstream of the weir, an array immediately downstream of the former Chiloquin Dam site, shoreline spawning areas, two river wide arrays near Braymill, and four antennas in the fish ladder on the Link River Dam (fig. 3.1). All detection systems were operating by February 25, 2009. The river-wide array located immediately upstream of the Williamson River fish weir and the antennas in the Link River fish ladder were operated continuously year around, whereas, the antennas located in the upstream and downstream weir traps, and the arrays located at the former Chiloquin Dam site and Braymill, were removed between May 21 and July 1, 2009. 


\section{Adult Fish Sampling}

We sampled adult fish in the Tulana Open Water and Agency Lake strata to compare relative catch rates of large piscivorous fish in the Williamson River Delta to Agency Lake. To sample large fish we used rectangular trap nets with mouth dimensions of $1.2 \times 1.8 \mathrm{~m}$, a $15-\mathrm{m}$ lead, and three internal fykes. These nets were made of green nylon netting with a mesh size of $25.4 \mathrm{~mm}$. Hereafter, these nets are referred to as large trap nets. A large trap net was set with three smaller trap nets at up to eight sites per week between 1056 and 1900 hours each day and pulled the next day between 0825 and 1744 hours. The protocols for setting and retrieving nets, measuring habitat characteristics, and counting and measuring fish, were the same for these large trap nets as for the smaller trap nets used for juvenile fish sampling.

\section{Summarizing and Reporting Data}

Juvenile fish catch data were summarized to describe spatial-temporal patterns in distribution, relative abundance, species composition, age distributions, and length distributions. We calculated catch rates to describe the magnitude of catches and naïve occupancy to describe the extent of spatial distribution. Catch rates were calculated as the number of fish per net set rather than the number of fish per hour because we could not determine any relation between the number of fish captured and the number of hours a net was fished. Naïve occupancy was calculated as the percentage of sites at which we caught at least one sucker in a category of interest. This value is known as the naïve occupancy rate because it has not been adjusted for a reduced probability of detection (MacKenzie and others, 2006).

A species and age specific relative weight assessment was conducted to examine relative condition of age-0 and age-1 juvenile suckers. Following Anderson and Neumann (1996), we fit weightlength data to a power curve to estimate a standard weight for a given length. The weight of each individual was then divided by its predicted weight and multiplied by 100 to calculate a relative weight. Because a relative weight of 100 was the standard by which fish were compared, relative weights greater than 100 indicated fish in good condition and those less than 100 indicated fish in poor condition relative to their peers. Because relative weights were not normally distributed and 30 or fewer fish were weighed from each stratum, we summarized these data by calculating median relative weight for each stratum.

Community structure was described through a series of graphs and calculations of weekly strata specific richness and diversity indices. Species richness is the number of taxa detected each week in each stratum. Taxanomic classifications included all non-sucker species and a single taxon for all suckers species combined. Relative diversity was calculated by dividing the Shannon-Wiener index of diversity for each week within each stratum by the maximum calculated in our study (McCune and Grace, 2002). This scaled the diversity indices to values between zero and one, where zero indicates a single species and one indicates relatively equal numbers of many species. Fish catch data from large trap nets were summarized to describe spatial and temporal patterns. Catch data for the most common predators were summarized to describe patterns in co-occurrence with larval and juvenile suckers. 


\section{Results}

Juvenile Fish Distribution and Condition

During 21 weeks of sampling in southern Agency Lake and the Williamson River Delta, we set 1,845 trap nets at 291 sites for a grand total of 38,369 hours of soak time. A total of 86 sites were visited once, 87 sites were visited twice, 117 sites were visited three times, and 1 site was visited four times, resulting in a total of 291 sites visited. A total of 207 sites were visited in spring, 185 in mid-summer, and 223 in late-summer for a total of 615 site visits in 2009. All nets were set in replicates of three but seven nets failed and were not included in this data summary. The duration of trap net samples ranged from 13.7 to 29.3 hours and averaged $20.9 \pm 4.3$ hours. We subsampled 220 net catches that weighed between 2.9 and $74.8 \mathrm{~kg}$ (mean $\pm \mathrm{SE}, 9.9 \pm 10.38$ ). The contents of a net that weighed $140 \mathrm{~kg}$ and contained primarily fathead minnows was not counted because of the extensive processing time required and limited staff time available.

\section{Spatial and Temporal Variation in Juvenile Sucker Distribution}

We captured a total of 887 juvenile suckers in the Williamson River Delta and Agency Lake. Based on weekly length frequency distributions, we estimated approximately 68.1 percent of these suckers were age-0 juveniles, 31.7 percent were age-1, and less than 1 percent were age-2 (fig. 3.2). We sacrificed 283 age- 0 and 50 age- 1 suckers for identification, histology, age validation, or collection of tissues for our fish health study. Sixty percent of age- 0 suckers were shortnose suckers, twenty three percent were suckers identified as having intermediate characteristics of Lost River, shortnose, or Klamath largescale suckers, fifteen percent were Lost River suckers and one percent were Klamath largescale suckers. Seventy-eight percent of age-1 suckers were shortnose, sixteen percent had characteristics intermediate of Lost River, shortnose, or Klamath largescale suckers, four percent were Lost River suckers, and only 2 percent of sacrificed age- 1 suckers were identified as Klamath largescale suckers.

Age-0 Juvenile Sucker Distribution

Identification of a subset of sacrificed suckers confirmed that age- 0 Lost River suckers were first present the week of July 5 and that shortnose suckers were first present the week of July 12 (figs. 3.3 and 2.4). Only four age-0 suckers sacrificed for identification were confirmed to be Klamath largescale suckers; two from Agency Lake, one from the Tulana Open Water stratum, and one from the Goose Bay stratum. All four Klamath largescale suckers were caught between July 27 and August 20. We also recorded relatively high catches of fish having intermediate characteristics of Lost River, shortnose, or Klamath largescale suckers beginning July 12.

There was a pattern of high age-0 sucker catch rates and the percentages of nets catching at least one age- 0 sucker, that shifted from shallow water in July to deep water in August and September (fig. 3.5). This pattern, however, was incomplete because decreasing lake-surface elevations prevented continuous access to shallow environments. At least one age- 0 sucker was caught at every Goose Bay site sampled between July 19 and August 23. Mean weekly catch rates and percentages of nets to catch at least one sucker were greatest in the Goose Bay stratum until it became too shallow to sample during the week of August 30 (figs. 3.6 and 3.7). Mean weekly catch rates peaked in the Tulana Emergent stratum the week of August 2, decreased by more than one-half the week of August 9 (fig. 3.7), and then the sites became too shallow to sample. Weekly catch rates and naïve occupancy rates increased between the weeks of July 12 and August 16 in the Tulana Submergent stratum (fig. 3.7). In this 
stratum, mean weekly catch rates dipped slightly the week of August 23 before they peaked during the week of September 6 (fig. 3.7). Age-0 suckers were not captured until the week of August 9 and peak catches did not occur until the week of September 6 in the deep water Tulana Open Water stratum. After age- 0 suckers were first detected in the Agency Near-Shore stratum during the week of July 19, there were no clear patterns in either the mean weekly catch rates or naïve occupancy rates (fig. 3.6). Both mean weekly catch rates and naïve occupancy rates in the Agency Off-Shore stratum increased between the weeks of August 9 and August 23, decreased the week of August 30, and increased again until we concluded our sampling the week of September 13 (fig. 3.6).

Age-0 suckers appeared to move from water depths less than $1 \mathrm{~m}$ in early July to water depths of 1.5 to $2.0 \mathrm{~m}$ in late July and early August (fig. 3.8). All age-0 sucker detections between the weeks of July 5 and July 19 occurred in less than $1 \mathrm{~m}$ of water. During the weeks of July 26 and August 2, the range in depths increased but median depths at sites where age-0 suckers were captured remained well below median depths of all sites sampled (fig. 3.8). After August 9, the distribution of depths measured at sites where age- 0 suckers were captured were similar to the distribution of depths sampled.

Age-0 juvenile suckers in our catches were smallest in the Tulana Emergent and Goose Bay strata where they were first captured (figs. 3.9 and 3.10). Median standard length for age-0 suckers steadily increased between the weeks of August 2 and September 13 in the Tulana Submergent stratum. In the Tulana Open Water stratum, median weekly standard length of age- 0 suckers increased between the weeks of August 9 and August 30, decreased slightly during the week of September 6, then increased again during the week of September 13. Patterns in age- 0 sucker standard length captured in the Agency Near-Shore stratum were not discernible because we captured too few fish (fig. 3.9). Median weekly standard length increased between the weeks of August 9 and August 23 but decreased slightly during the week of August 30 before peaking the week of September 6 in the Agency Off-Shore stratum.

Age-0 Juvenile Sucker Condition

Twenty-six age- 0 Lost River suckers and 90 age- 0 shortnose suckers were weighed prior to dissection and therefore suitable for inclusion in our species specific relative weight assessment. Fitting the power curve described by Anderson and Neumann (1996) to juvenile Lost River sucker weightlength data (fig. 3.11) yielded the equation;

$$
\text { Weight }=\left(1.82 \times 10^{-5}\right) \cdot \text { Length }^{2.95}, \mathrm{R}^{2}=0.92
$$

Fitting a power curve to juvenile shortnose sucker weight-length data (fig. 3.11) yielded the equation;

$$
\text { Weight }=\left(3.37 \times 10^{-5}\right) \cdot \text { Length }^{2.87}, \mathrm{R}^{2}=0.96 \text {. }
$$

Too few suckers were caught in each stratum to make meaningful comparisons of median relative weight (table 3.2). 
External examination of age- 0 suckers indicated few deformities, macroparasites, overt signs of illness, or injuries. Nine percent of age- 0 suckers had one deformed opercle and 3 percent had both opercles deformed. Twenty-five percent of age- 0 suckers with deformed opercles were identified as shortnose suckers, 8 percent were Lost River suckers, and 7 percent had characteristics intermediate to the three lake suckers discussed in this report. The rest were not sacrificed nor identified to the species level. Ninety age-0 suckers (14.9 percent) were noted to have at least one anchorworm (Lernaea spp.). Of the age- 0 suckers with anchorworms, 75 percent had only one. Only one sucker had more than 10 anchorworms. Thirty-one percent of age- 0 suckers with anchorworms were Lost River suckers, 13 percent were shortnose suckers, 7 percent had characteristics intermediate to the three suckers discussed in this report, and the rest were not sacrificed for species identification. Small numbers of age-0 suckers also were noted to have scoliosis (2), blindness (2), cysts (3), black spot disease (1), contusions (1), or red rashes (4). Seventeen age-0 suckers had fin deformities on either pelvic or caudal fins. These fish may have been recaptured individuals that had previously had fin tissue removed.

Age-1 and Age-2 Juvenile Sucker Distribution

Mean weekly age-1 sucker catch rates were greatest in the shallow water Tulana Emergent and Goose Bay strata between the weeks of May 3 and May 24, but greatest in deep-water Agency OffShore and Tulana Open Water strata during the week of June 28 (fig. 3.12). Mean weekly catch rates were greatest the week of May 3 but naïve occupancy rates peaked the week of May 17 in the Tulana Emergent stratum (fig. 3.13). In this stratum, naïve occupancy and mean weekly catch rates decreased to zero during the weeks of June 14 and June 28, increased during the weeks of July 5 and July 12, and decreased to zero until this strata was too shallow to sample. In the Goose Bay stratum, mean weekly catch rates peaked the week of May 17, decreased to a low level between the weeks of May 31 and July 19, and before the stratum became too shallow to sample (fig. 3.14). Age-1 suckers were consistently captured at low rates and at 60 percent or fewer sites sampled between the weeks of May 3 and July 19 in the moderately deep Tulana Submergent stratum (fig. 3.13). After the week of July 19, however, age1 suckers were only detected during 3 of 8 sampling weeks in this stratum. Catches of age- 1 suckers were intermittent in the Agency Near-Shore and Agency Off-Shore strata, and no age-1 suckers were detected after the week of July 12 in the Agency Off-Shore stratum or after the week of August 2 in the Agency Near-Shore stratum (fig. 3.14).

A comparison of the water depths sampled to the water depths at which age-1 suckers were collected indicated selection of relatively shallow depths throughout May, the first week in June, and the week of July 12 (fig. 3.15). Age-1 sucker catches shifted from median water depths of 1.1-1.5 m during the weeks of May 3-June 7 to median water depths of 2.1-2.2 m during the weeks of June 14-July 5. Finally during the week of July 12 , median water depths at sites where age-1 suckers were captured declined to less than $1 \mathrm{~m}$, just before the near-disappearance of age-1 suckers in our samples. 
Age-1 Sucker Condition

Ten age-1 shortnose suckers, one age-1 Klamath largescale sucker, and four age- 1 suckers with characteristics intermediate of the three sucker species were weighed prior to dissection. Fitting the power curve described by Anderson and Neumann (1996) to age-1 weight-length data for all sucker species combined (fig. 3.16) yielded the equation:

$$
\text { Weight }=\left(1.32 \times 10^{-5}\right) \cdot \text { Length }^{3.05}, \mathrm{R}^{2}=0.97 .
$$

Relative weights of age-1 suckers were not compared among strata or species because there was not enough data.

Age-2 or older subadult suckers were much less common in our catches than age- 1 suckers. We captured a total of two suckers that we estimated to be at least 2 years old based on weekly length frequency distributions. One was captured in the Tulana Submergent stratum on June 3 and was 169 $\mathrm{mm}$. The other was captured in the Agency Near-Shore stratum on June 23 and was $179 \mathrm{~mm}$.

External examination of age- 1 and age- 2 suckers indicated that deformities, macroparasites, and overt signs of illness or injury were uncommon. Five percent of age-1 and age- 2 suckers had one deformed opercle and 2 percent had both opercles deformed. Ten percent of age- 1 suckers with deformed opercles were identified as shortnose suckers, 5 percent had characteristics intermediate to the three lake suckers discussed in this report. The rest were not sacrificed nor identified to species. Fiftytwo age- 1 suckers and one age- 2 sucker had at least one anchorworm. Of the age- 1 and age-2 suckers with anchorworms, 35 percent had only one anchorworm and one had 10 anchorworms. Small numbers of age-1 suckers also were noted to be blind (3), have red rashes (1), or have lamprey wounds (1). Nine age-1 suckers had fin deformities on either their pelvic or caudal fins. These fish may have been recaptured individuals that previously had fin tissue removed.

\section{Age-1 Sucker PIT Tag Summary}

We PIT tagged a total of 132 age-1 and 2 age-2 suckers between April 17 and June 26. We stopped tagging at the end of June, because increasing air and water temperatures appeared to cause these fish undue stress. Of these tagged fish, 76 percent were released in either the Tulana Emergent or Goose Bay strata, 9 percent were released in the Tulana Submergent stratum, 8 percent were released in Agency Lake stratum, and 6 percent were released in the Tulana Open Water stratum. Six of these PITtagged suckers were detected September 30 or October 1 at an American white pelican colony in the Upper Klamath Wildlife Refuge (A. Evens, Bird Research Northwest, written commun., October 29, 2009). Seven suckers PIT tagged in this project were detected on remote arrays at the Williamson River weir approximately $6 \mathrm{~km}$ upstream of the Williamson River Delta (fig. 3.1). Of these, one was detected on July 8, two were only detected between June 4 and June 9, and three were detected between May 26 and June 11 and detected again between July 17 and August 30. The seventh PIT tagged sucker was tagged on April 17 in the Tulana Emergent stratum, detected at the Williamson River weir 17 times between April 29 and June 9, detected downstream of, then upstream of the former site of the Chiloquin Dam on June 12, then detected two more times at the weir on July 16 and August 8, for a total travel distance of more than $20 \mathrm{~km}$. 


\section{Fish Community and Distribution of Piscivorous Fishes}

We captured 13 non-sucker fishes in our small trap net sampling between May 5 and September 28. Our catches were dominated by fathead minnow, but tui chub, blue chub and yellow perch also were common in our catches (fig. 3.17). Klamath Lake sculpin, brown bullhead, lamprey, pumpkinseed, Upper Klamath marbled sculpin, slender sculpin, speckled dace, largemouth bass, and redband trout (listed in descending order of abundance) were less common in our catches. Mean weekly catch rates for all species combined were variable and less than 733 fish per net between the weeks of May 3 and August 2. However, catch rates substantially increased due to high catches of fathead minnows starting the week of August 16 in the Agency Off-Shore stratum, the week of August 23 in the Agency NearShore stratum, and the week of August 30 in the Tulana Submergent and Tulana Open Water strata.

Fathead minnows made up more than one-half of the fish caught in the Tulana Submergent, Tulana Open Water, Agency Near-Shore, Agency Off-Shore strata nearly every week (figs. 3.17 and 2.18). Blue and tui chub were caught in nearly equal proportion to fathead minnows in the Tulana Submergent stratum during the week of May 3. Tui chub were the most abundant species in our catches in the Tulana Open Water stratum during the weeks of May 24 and June 28. Large numbers of tui chub were caught in both Agency Lake strata between the weeks of June 7 and July 5. The greatest mean weekly catch rates for fathead minnows occurred in the Agency Near-Shore stratum during the week of July 19, and the lowest occurred in the Tulana Emergent and Tulana Submergent strata during the same week.

Diversity was low in all strata primarily due to an overwhelmingly high abundance of fathead minnows. The greatest relative diversity occurred in the Tulana Emergent stratum during the week of July 26, when yellow perch, blue chub, and brown bullhead were abundant (figs. 3.17 and 3.18). Relative diversity indices were frequently greatest in the Tulana Emergent and Goose Bay strata (figs. 3.17 and 3.18). High relative diversity was associated with lower catch rates of fathead minnows and greater catch rates of tui chub, blue chub, and yellow perch.

Piscivorous species captured in our small trap net sampling included fathead minnows, largemouth bass, redband trout, and yellow perch. Largemouth bass and redband trout were rarely detected in our small trap net sampling. The eight largemouth bass captured in this study were 35-91 $\mathrm{mm}$. Six redband trout were 39-97 mm and one was $174 \mathrm{~mm}$. All but one largemouth bass was captured in the Agency Near-Shore stratum; whereas, redband trout were captured in the Tulana Emergent, Goose Bay, and both Agency Lake strata.

Examination of weekly length data indicated at least two cohorts of yellow perch (fig. 3.19). Between the weeks of May 3 and June 21, the larger cohort primarily was captured in the Tulana Emergent stratum (fig. 3.20). After June 21, the greatest mean weekly catch rates for the older cohort of yellow perch occurred in the Tulana Emergent and Goose Bay strata (fig. 3.20). Mean weekly catch rates were greatest for the younger cohort of yellow perch in the Tulana Emergent stratum between the weeks of July 5 and July 12 and in the Goose Bay stratum between July 26 and August 2 (fig. 3.20).

We captured blue chub, tui chub, brown bullhead, pumpkinseed, yellow perch, and lamprey in

the large trap nets. Most of these fish were gilled in the lead net rather than trapped in the cod end. Most fish caught in the large trap nets were blue and tui chub. Piscivorous species were uncommon in our large net catches with the exception of yellow perch. At least one yellow perch was captured in 35 percent of large trap nets set in the Tulana Open Water stratum, 15 percent of sets in the Agency NearShore stratum, and 10 percent of sets in the Agency Off-Shore stratum. Yellow perch captured in large trap nets and the larger cohort of yellow perch captured in small trap nets were similar in size. 
Many small trap net sets in the Williamson River Delta caught no fish (20) or contained all dead or moribund fish when retrieved (18). For comparison, only three empty nets and only four nets with dead or dying fish were noted in the Agency Off-Shore stratum and none in the Agency Near-Shore stratum. Dead fish in nets included fathead minnows, tui chub, and yellow perch. Occasionally these nets contained several hundred dead and dying fish, but most had less than a few dozen dead or moribund fish. Nets that caught no fish occurred as early as May 4 and as late as August 20 and nets with dead fish were observed between June 2 and August 5. The greatest concentration of these emptynet or high in-net-mortality events occurred in the Tulana Open Water, Tulana Submergent, and Agency Off-Shore strata at water depths of 1.8-3.2 m between July 16 and July 23, when 13 high in-netmortality events were followed by 7 empty net events. During this period, 65 percent of these events occurred in the Tulana Open Water stratum.

\section{Discussion}

\section{Comparison of Juvenile Sucker Catch Rates among Years and Water-bodies}

A comparison in catch data between years, when the same sampling protocols were used to sample in all three areas, indicated that age-0 suckers were relatively more abundant in 2009 than 2008 throughout our study area and Upper Klamath Lake, but were similarly distributed among strata in both years (Burdick and others, 2009b). Peak weekly mean catch rates for age-0 suckers were greater in 2009 than in 2008 in the Williamson River Delta, Agency Lake, and Upper Klamath Lake (U.S. Geological Survey, unpub. data, 2009). Peak weekly naïve occupancy rates calculated by strata also were equal or greater within the Williamson River Delta, Agency Lake, and Upper Klamath Lake in 2009 than 2008 (Burdick and others, 2009b). For strata sampled in both years, the rank of highest to lowest peak mean weekly catch rates for age-0 suckers was the same in 2008 and 2009: Tulana Submergent, Tulana Open Water, Agency Lake, and Tulana Emergent strata (Burdick and others, 2009b).

Of the habitats sampled in the Williamson River Delta, Agency Lake, and Upper Klamath Lake, catch rates were greatest in Goose Bay and lowest in the Tulana Emergent strata. Peak mean weekly catch rates for age-0 suckers in Goose Bay were 1.7 times greater than in any other strata sampled in these two studies. In contrast, the Tulana Emergent stratum, which had similar water depths as the Goose Bay stratum, had the lowest peak mean catch rate of any strata sampled in either study, with the exception of an off-shore area in the southern end of Upper Klamath Lake. In this off-shore area, catch rates were only 0.2 fish per net higher than catch rates were in the Tulana Emergent stratum in 2009.

A comparison of peak mean weekly catch rates calculated by strata indicated that the peak abundance of age-1 suckers in Agency and Upper Klamath lakes was up to 10 times greater in 2009 (U.S. Geological Survey, unpub. data, 2009) than in 2008 (Burdick and others, 2009b). When age-1 sucker catches in strata within the Williamson River Delta were compared between 2008 and 2009, however, results were equivocal. Mean $( \pm$ SD) weekly catch rates calculated for the weeks of May 3 ( $4.7 \pm 14.9$ age- 1 suckers per net) and May 17 (1.5 \pm 2.1 age- 1 suckers per net $)$ in the Tulana Emergent stratum in 2009 were both greater than the peak mean weekly age- 1 sucker catch rate of $0.17 \pm 0.34$ per net for this stratum in 2008. Peak mean weekly catch rates and naïve occupancy rates were equal to or greater in 2008 than in 2009 in the Tulana Submergent and Tulana Open Water strata. The 2008 peak catches, however, occurred during weeks when only one site was sampled in each of the Tulana strata. 
Catch rates of age-1 and older juvenile suckers in Upper Klamath Lake and the surrounding aquatic habitats commonly are low. Markle and Simon (1993) set 27 overnight trap nets (904 soak hours) during April and May 1992 and captured 76 age-1 or older juvenile suckers in tributaries of Upper Klamath Lake, but only 4 in the lake itself. Their overall catch rate of age- 1 suckers $(0.35$ suckers per net) was somewhat similar to our peak mean weekly catch rates calculated for all strata within the Williamson River Delta and Agency Lake in 2009, except the two shallowest and most river-effected strata: Tulana Emergent and Goose Bay. Markle and Simon (1993) attributed small relative catches of suckers, when compared to total catch size, to their sedentary nature, which contrasts with more active blue and tui chub. Differences in detectability among species are a major factor in estimating abundance from catch rates, but consistently low catches of young suckers using passive and active gears indicate that the abundance of these fishes actually may be low in Upper Klamath Lake and adjacent aquatic habitats. From 1996 to 2007, Simon and Markle (2008) sampled with otter trawls in off-shore areas of Upper Klamath Lake between April and May. In this long-term monitoring program, seasonal catch rates never exceeded 0.15 suckers per $20-\mathrm{m}$ tow, providing further evidence that spring abundance of age-1 suckers within Upper Klamath Lake is low. Catch rates reported for age-1 suckers collected from Upper Klamath Lake in 2007 using the same sampling protocols as the current study (Burdick and others, 2009b) also exhibited catch rates less than 0.47 fish per net.

\section{Juvenile Sucker Species Composition}

Shortnose suckers made up the greatest portion of juvenile sucker species captured in the Williamson River Delta in 2008 and 2009. Age-0 shortnose suckers outnumbered age-0 Lost River suckers in our Williamson River Delta samples by a ratio of 2:1 in 2008 (Burdick and others, 2009b) and 4:1 in 2009, and in our Agency Lake samples by a ratio of 3:1 in 2009. In contrast, age-0 shortnose and age-0 Lost River suckers were equally abundant in our catches in Upper Klamath Lake in 2008 (Burdick and VanderKooi, 2010), and age-0 Lost River suckers were more abundant than age-0 shortnose suckers in our catches in Upper Klamath Lake in 2007 and 2009, and in Agency Lake in 2008. Age-1 shortnose suckers outnumbered age-1 Lost River suckers by a ratio of 18:1 in the Williamson River Delta and 9:1 in Upper Klamath Lake in 2009. No age-1 suckers sacrificed for species identification from Agency Lake in 2009 were identified as Lost River suckers. Age-1 shortnose suckers outnumbered age-1 Lost River suckers in Upper Klamath Lake by a ratio of 1.5:1 in 2008 and $8: 1$ in 2007. None of the four age-1 suckers sacrificed from the Williamson River Delta or the one age-1 sucker sacrificed from Agency Lake in 2008 were identified as shortnose suckers.

High abundance of shortnose suckers relative to other sucker species in the Williamson River Delta may indicate that the environment in this area is more suitable for this species than for Lost River suckers. High relative abundance of age-1 shortnose suckers compared to Lost River suckers in our catches may indicate shortnose suckers experienced better survival rates than Lost River suckers in 2008. Alternatively, high abundances of shortnose suckers may be the result of inter-annual variation in species specific production rates, survival rates, or both. 


\section{Juvenile Sucker Distribution}

Distributional patterns in relation to water depth for age-0 juvenile suckers throughout the Williamson River Delta were similar to those observed in other parts of Upper Klamath Lake. Within Upper Klamath Lake, age-0 suckers are habitat generalists (Burdick and others, 2008) that use shallow (0.5-3.0 m) (Buettner and Scoppettone, 1990; Terwilliger and others, 2004; Hendrixson and others, 2007; Burdick and others, 2009a; Burdick and VanderKooi, 2010), sometimes vegetated water (Hendrixson and others, 2007; Burdick and others, 2008a), and are otherwise habitat generalists (Burdick and others, 2008a). Age-0 juvenile suckers frequently used shallow water $(<1 \mathrm{~m})$ in May and early June, but appeared to move to water 1.5-2.0 $\mathrm{m}$ deep in late July as the lake elevation declined.

In 2009, weekly catch rates were highest in the shallow-water Tulana Emergent and Goose Bay strata in May, the mid-depth Tulana Submergent stratum in June, and then the Tulana Open Water stratum, Agency Lake and Upper Klamath Lake during the week of June 28 (U.S. Geological Survey, unpub. data, 2009). Therefore, it appears that age-1 suckers may have migrated from shallow water on the east side of delta at the end of June. A shift in the use of shallow water median water depths less than $1.5 \mathrm{~m}$ between the weeks of May 3 and June 7 to deeper water $(>2.1 \mathrm{~m})$ from June 14 to July 5 provides further evidence of a seasonal change in habitat use. A similar shift from shallow to deep water also occurred in Upper Klamath Lake in 2007 and 2008 (Burdick and others, 2009a; Burdick and VanderKooi, 2010) and in the Tulana Unit in 2008 (Burdick and others, 2009a), but was not detected in Upper Klamath Lake in 2009 (U.S. Geological Survey, unpub. data, 2009). Median depth at which most age-1 suckers were detected after mid-June varied among years, but was always as deep as or deeper than the median water depth sampled in each year. The deepest median water depth occupied by age-1 suckers in the Williamson River Delta in 2009 occurred between June 14 and July 5 and was around 2 $\mathrm{m}$ (fig. 3.15). During the same time period in Upper Klamath Lake the most used depth class by age-1 suckers was 2-3 m in 2009 (U.S. Geological Survey, unpub. data, 2009). In contrast, the most used depth class by age-1 suckers in Upper Klamath Lake was 4-5 m in 2007 and 6-7 $\mathrm{m}$ in 2008 (Burdick and others, 2009a; Burdick and VanderKooi, 2010) and 3-6 m in 2008 in the Tulana Unit (Burdick and others, 2009b). It is unclear what might be driving this apparent shift from the use of shallow to deep water in early June by age-1 suckers. Determining the causes, however, could help identify which habitat characteristics or migration pathways are most important to preserve, restore, or create habitat for age-1 and older juvenile suckers.

\section{Juvenile Sucker Deformities and Parasites}

Juvenile suckers generally appeared to be in good condition with only 9 percent of age- 0 and 5 percent of age- 1 and age- 2 suckers having deformed opercles. These rates of opercle deformity were greater than rates reported for similarly sized age-0 Lost River (4.7 percent) and shortnose (1.4-3.1 percent) suckers of a similar size to our age-0 suckers, collected in 1993 (Plunkett and Snyder-Conn, 2000). The deformity rates in the Williamson River Delta in 2009, however, were lower than for age-0 (25 percent) and age-1 (9 percent) suckers collected in 2008 (Burdick and others, 2009b) or for age-0 (17 percent) suckers collected in 2009 in Upper Klamath Lake (U.S. Geological Survey, unpub. data, 2009). Other deformities have been observed for these species (Plunkett and Snyder-Conn, 2000), however, we did not observe them in X-rays or external examination of fish we collected. 
Opercle deformities that expose gill filaments, such as those observed on age-0 suckers in 2008, are a common phenomenon in hatchery fish but are less prevalent in wild fish (Beraldo and others, 2003). These deformities are non-lethal for hatchery-raised fish (Beraldo and others, 2003), but may lower resistance to oxygen stress and predispose fish to infections by bacteria, parasites, and fungi (Galeotti and others, 2000; Beraldo and others, 2003). These deformities also could be caused by inbreeding (Winemiller and Taylor, 1982; Tringali and others, 2003). Two other potential causes of this particular deformity are a lack of dietary ascorbic acid (Chávez de Martínez, 1990) and pollution (Lindesjoo and others, 1994). A lack of dietary calcium or low environmental pH during periods of rapid growth also may cause erratic or limited skeletal development resulting in shortened opercula (Lindesjoo and others, 1994). In Upper Klamath Lake, however, daily median $\mathrm{pH}$ is rarely less than 8.0 (Lindenberg and others, 2008). Whatever the cause, skeletal deformities, such as shortened opercula, are irreversible (Beraldo and others, 2003). Therefore, the lower incidence of this condition in older suckers may indicate that elevated mortality is associated with shortened opercula in our study area. An observational study that examines rates of deformities over a number of years and a large geographic range may generate candidate causes. A laboratory study, however, would be required to determine an actual relation between cause and effect.

\section{PIT Tag Detections}

The 8 percent detection rate of age- 1 and age- 2 suckers in the Williamson River Delta demonstrates the potential for PIT-tag technology to be used to study sources of mortality and movement of age-1 suckers in Upper Klamath Lake. Because both American white pelicans and doublecrested cormorants primarily feed on live fish (Derby and Lvvorn, 1997), we assume that these fish were eaten alive and did not die of other causes. However, little effort was put into detecting tags at nest sites for birds that primarily prey on dead or moribund fish. It is possible that predators, such as redband trout, may have eaten suckers with PIT tags and detections on remote antennas may indicate the presence of predators but not live suckers. It is more likely, however, that tags detected on remote antennas were in live suckers for two reasons. If a predator ate a PIT-tagged fish, it would likely pass the tag within several days and not be detected on passive antenna systems. Multiple detections over several months, however, indicated that tags were not being passed through digestive systems of predators, but were detections of live suckers.

\section{Distribution of Piscivorous Fishes}

Only two piscivorous fishes appeared to pose any sort of meaningful threat of predation to suckers, fathead minnows and yellow perch. Fathead minnows prey on larval suckers (Markle and Dunsmore, 2007) but are not large enough to prey on juveniles. Yellow perch can prey on fish up to 47 percent of their body length (Truemper and Lauer, 2005). Therefore, the smaller cohort of yellow perch in this study could only prey upon larval suckers. The larger cohort of yellow perch could prey on age- 0 juvenile suckers but not on age-1 suckers. The largest yellow perch we captured was $220 \mathrm{~mm}$ and could theoretically ingest a $103 \mathrm{~mm}$ sucker, which is smaller than the median length of age- 1 suckers leading up to and during the week of July 19. Based on their size, the eight largemouth bass we captured were capable of preying on age-0 suckers until mid-August (Hambright, 1991), but the seven redband trout we captured could only prey on larvae (Keeley and Grant, 2001). 
Fathead minnows dominated catches in all strata, but made up a smaller portion of fish caught in the shallow-water Goose Bay and Tulana Emergent strata than in other strata. Therefore, there was a lower fathead minnow to larval shortnose or Klamath largescale sucker ratio in the Goose Bay and Tulana Emergent strata than in other areas in 2009 (see chapter 1; The Nature Conservancy, 2010). Fathead minnows also were least abundant in our catches in the Tulana Emergent stratum in 2008 when compared to other parts of the delta and Agency Lake (Burdick and others, 2009b). Peak mean weekly catch rates by strata for fathead minnows were at least 50 percent greater in 2009 than in 2008 in all strata sampled in both years. The greatest inter-annual increase in fathead minnow catch rates occurred in Agency Lake where peak mean weekly fathead minnow catch rates were more than five times greater in 2009 than in 2008.

\section{Influence of Water Quality on Fish Distribution}

Water quality in the Williamson River Delta and the adjacent lakes appeared to be associated with blooms of cyanobacteria (The Nature Conservancy, 2010). This follows a well-established pattern in Upper Klamath Lake, in which a pattern of high $\mathrm{pH}$ is followed by periods of low DO concentrations and relatively high ammonia (Lindenberg and others, 2008). In 2009, this pattern occurred between early June and late July and between mid-August and mid-September. The early June to late July occurrence produced more severe conditions in the Tulana Unit of the Williamson River Delta than elsewhere and the mid-August to mid-September occurrence produced more severe conditions in Agency Lake than in other parts of our study area (The Nature Conservancy, 2010). These occurrences, however, did not appear to influence water quality in Goose Bay as much as the inflow from the Williamson River (The Nature Conservancy, 2010).

Levels of $\mathrm{pH}$ exceeded tolerance limits for suckers in all strata except the Goose Bay and Tulana Emergent strata (The Nature Conservancy, 2010), but did not influence distribution of juvenile suckers. The maximum recorded $\mathrm{pH}$ during the period of our study was greater than 9.55 , the mean tolerance limit for shortnose suckers (Falter and Cech, 1991), and greater than 9.70, a high stress threshold reported by Loftus (2001), in all strata except Goose Bay (The Nature Conservancy, 2010). Maximum $\mathrm{pH}$ measured throughout the study area did not exceed 10.7, a level at which juvenile suckers survived but experienced convulsions, erratic swimming behavior, excessive mucous production, or hemorrhaging from gills or eyes (Saiki and others, 1999). Levels of $\mathrm{pH}$ exceeded the high stress threshold for the entire day for 15 consecutive days in the Tulana Open Water and Tulana Submergent strata and more than 50 percent of each day for a similar duration in Agency and Upper Klamath lakes during mid-June (The Nature Conservancy, 2010). This high-pH event occurred during peak mean weekly catches of age-1 suckers in the Tulana Open Water and both Agency Lake strata, and moderately high catches in the Tulana Submergent stratum. Peak mean weekly catch rates for age-0 suckers in the Tulana Open Water and Tulana Submergent strata occurred during a second high $\mathrm{pH}$ event that occurred in these areas at the end of August but was less severe and shorter.

High water temperatures only occurred in shallow water and did not appear to influence juvenile sucker distribution. Temperatures exceeding $28^{\circ} \mathrm{C}$, a high stress threshold for juvenile suckers (Loftus, 2001), were only recorded in the Tulana Emergent and Goose Bay strata at the end of July and beginning of August (The Nature Conservancy, 2010). During this period, age-1 suckers were not captured in the Tulana Emergent stratum and were caught at low rates in the Goose Bay stratum. Catches of age-1 suckers, however, also were near zero in cooler and deeper strata. Mean weekly age-0 sucker catch rates peaked in these two strata coinciding with high water temperatures. 
Periodic high concentrations of unionized ammonia in the Williamson River Delta could have caused negative physiological responses in juvenile suckers during 2009. Concentrations of unionized ammonia in the Tulana Open Water and Tulana Emergent strata exceeded $0.51 \mathrm{mg} / \mathrm{L}$ (The Nature Conservancy, 2010), a level at which one-half of juvenile shortnose suckers have been shown to die if exposure continues for 24 hours or more (Saiki and others, 1999). These concentrations only occurred, however, on a single occasion in each of these strata (The Nature Conservancy, 2010). Sub-lethal concentrations of unionized ammonia may actually stimulate mucous production that helps fish to resist the potentially lethal gill pathogen Flexibacter columnare (Morris and others, 2006).

Periodic low DO concentrations could cause negative physiological responses in juvenile suckers in our study area. DO concentrations less than $4.00 \mathrm{mg} / \mathrm{L}$, a high stress threshold for suckers (Loftus, 2001), were recorded for more than 30 percent of each day from the end of June to the end of July in the Tulana Emergent stratum (The Nature Conservancy, 2010). During mid-July, DO concentrations less than $4.00 \mathrm{mg} / \mathrm{L}$ also were recorded continuously for 9 days in the Tulana Open Water stratum, up to 80 percent of each day for a period of less than 2 weeks in the Tulana Submergent stratum, and less than one-half of each day for a period of about 1 week in Agency Lake (The Nature Conservancy, 2010). A second low event began in mid-September, after we discontinued sampling for the season. DO concentrations occasionally decreased to less than $1.70 \mathrm{mg} / \mathrm{L}$ in the Tulana Open Water and Tulana Submergent strata and in Upper Klamath and Agency lakes, and less than $1.00 \mathrm{mg} / \mathrm{L}$ in the Tulana Emergent stratum (The Nature Conservancy, 2010). In the Goose Bay stratum, however, DO concentrations were not less than $2.4 \mathrm{mg} / \mathrm{L}$ in 2009. Saiki and others (1999) reported that 50 percent of juvenile Lost River suckers died when held in DO concentrations less than $1.58 \mathrm{mg} / \mathrm{L}$, for 24 hours or more, without access to the surface and that 50 percent of juvenile shortnose suckers died when held in DO concentrations of $1.14 \mathrm{mg} / \mathrm{L}$ or less. Juvenile suckers can survive in completely anoxic conditions by gulping air if they can access the surface, but not without physiological consequences (Foott and others, 2007). Suckers in anoxic or near anoxic conditions that can access the surface cease to feed and their glycogen reserves are diminished (Foott and others, 2007). Therefore, low DO concentrations that force juvenile suckers to the surface may increase the risk of avian predation and reduce the ability of young suckers to survive the winter when prey availability may be limited.

Low catch rates of both age- 0 and age- 1 suckers in our small trap net sampling coincided with low DO concentrations. The decline in age-1 catches to zero or near zero coincided with the July low DO events in all strata. A slight, but temporary increase in catch rates for age-1 suckers occurred in the Tulana Open Water stratum coinciding with increases in DO concentrations. Catch rates for age- 0 suckers did not increase until after the first low DO event had ended in all strata except Goose Bay, where low DO events were least severe. These patterns indicate that juvenile suckers were either able to avoid low DO concentrations, died during low dissolved oxygen events, or ceased to move and were undetectable. 
Poor July water quality in the Williamson River Delta also may explain timing and location of nets that were empty or those that contained only dead and moribund fish. These incidents primarily occurred in mid-July in Tulana Open Water, Tulana Submergent, and Agency Off-Shore strata where low DO events were most severe (The Nature Conservancy, 2010). During July, DO concentrations in the Williamson River Delta and Upper Klamath Lake follow a diel pattern, with lows occurring around $0700 \mathrm{~h}$ and highs occurring around $1800 \mathrm{~h}$ (The Nature Conservancy, 2009). We assume that fish entered our nets on their own initiative when water-quality conditions were survivable. Then, because they were trapped in our gear, these fish were unable to escape when DO concentrations decreased to their lowest point early in the morning (The Nature Conservancy, 2009). Therefore, our experience with high fish mortality in several of our nets does not raise concerns about the effect of fluctuating DO concentrations in the delta on overall survival because uncaptured fish may survive by temporarily emigrating from poor water-quality environments or gulping air.

\section{Summary}

We collected and summarized data in this chapter to describe patterns in habitat use by juvenile endangered suckers in the Williamson River Delta restoration area in 2009. Age-0 Lost River juvenile suckers were first detected the week of July 5 and age-0 juvenile shortnose suckers were first detected the week of July 12. Of the habitats sampled in the Williamson River Delta, Agency Lake, and Upper Klamath Lake, catch rates were greatest in the shallow Goose Bay stratum and lowest in the shallow Tulana Emergent stratum. Shortnose suckers outnumbered Lost River suckers in our Williamson River Delta catches, which may indicate that the environment in this area is more suitable for shortnose suckers than for Lost River suckers. Age-0 juvenile suckers appeared to move from water depths less than $1.0 \mathrm{~m}$ in early July to water depths of 1.5 to $2.0 \mathrm{~m}$ in late July and early August. Age- 1 suckers, on the other hand, appeared to move from water depths of 1.1-1.5 $\mathrm{m}$ in May and early June to water depths of 2.1-2.2 m during late June and early July, and then to water depths less than $1.0 \mathrm{~m}$ in mid to late July. Eight percent of PIT tagged age-1 and older juvenile suckers were detected on American white pelican colonies or as far as $6 \mathrm{~km}$ upstream in the Williamson River, which indicates avian predation is a source of mortality for juvenile suckers in the Williamson River Delta, and that juvenile suckers can travel long distances.

Habitat in the Williamson River Delta presented juvenile suckers with challenges similar to those found in Upper Klamath and Agency lakes. Two piscivorous fishes appeared to pose a threat of predation to suckers, fathead minnows, and yellow perch. Periodically high levels of $\mathrm{pH}$, warm water, and high concentrations of unionized ammonia in the Williamson River Delta surpassed hypothesized stress thresholds for juvenile suckers. Juvenile suckers were captured despite these extreme water quality conditions. Low catch rates of both age- 0 and age-1 suckers, however, coincided with low DO concentrations, indicating that juvenile suckers were able to avoid low DO concentrations, died during low dissolved oxygen events, or ceased to move and were undetectable. 


\section{References Cited}

Anderson, R.O., and Neumann, R.M., 1996, Length, weight, and associated structural indices in Murphy B.R., and Willis, D.W., eds., Fisheries Techniques, 2nd edition: American Fisheries Society, Bethesda, Maryland, p. 447-482.

Beck, M.W., Heck, K.L., Able, K.W., Childers, D.L., Eggleston, D.B., Gillanders, B.M., Halpern, B., Hays, C.G., Hoshino, K., Minello, T.J., Orth, R.J., Sheridan, P.F., and Weinstein, M.P., 2001, The identification, conservation, and management of estuarine and marine nurseries for fish and invertebrates: BioScience, v. 51, p. 633-641.

Beraldo, P., Pinosa, M., Tibaldi, E., and Canavese, B., 2003, Abnormalities of the operculum in gilthead sea bream (Sparus aurata): morphological description: Aquaculture, v. 220, p. 89-99.

Buettner, M., and Scoppettone, M.M., 1990, Life history and status of Catostomids in Upper Klamath Lake, Oregon: Oregon Department of Fish and Wildlife, Klamath Tribe, and National Fisheries Research Center, Reno, Nevada.

Burdick, S.M., Anderson, G.O., and VanderKooi, S.P., 2009a, Spring and summer spatial distribution of endangered juvenile Lost River and shortnose suckers in relation to environmental variables in Upper Klamath Lake, Oregon: 2007 Annual Report: U.S. Geological Survey Open-File Report 2009-1043, 56 p. (Also available at http://pubs.usgs.gov/of/2009/1043/.)

Burdick, S.M., Hendrixson, H.A., and VanderKooi, S.P., 2008a, Age-0 Lost River sucker and shortnose sucker nearshore habitat use in Upper Klamath Lake, Oregon: a patch-occupancy approach:

Transactions of the American Fisheries Society, v. 137, p. 417-430, doi: 10.1577/T07-072.1, accessed August 13, 2010, at http://afsjournals.org/doi/pdf/10.1577/T07-072.1.

Burdick, S.M., Ottinger, C., Brown, D.T., VanderKooi, S.P., Robertson, L., and Iwanowicz, D., 2009b, Distribution, health, and development of larval and juvenile Lost River and shortnose suckers in the Williamson River Delta restoration project and Upper Klamath Lake, Oregon: 2008 annual data summary: U.S. Geological Survey Open-File Report 2009-1287, 76 p. (Also available at http://pubs.usgs.gov/of/2009/1287/.)

Burdick, S.M., and Vanderkooi, S.P., 2010, Temporal and spatial distribution of endangered juvenile Lost River and shortnose suckers in relation to environmental variables in Upper Klamath Lake, Oregon: 2008 annual data summary: U.S. Geological Survey Open-File Report 2010-1051, 36 p. (Also available at http://pubs.usgs.gov/of/2010/1051/.)

Burdick, S.M., Wilkens, A.X., and VanderKooi, S.P., 2008b, Near-shore and off-shore habitat use by endangered, juvenile Lost River and shortnose suckers in Upper Klamath Lake, Oregon: 2006 data summary: U.S. Geological Survey Open-File Report 2007-1356, 30 p. (Also available at http://pubs.usgs.gov/of/2007/1356/.)

Chávez de Martínez, M.C., 1990, Vitamin C requirement of the Mexican native cichlid Cichlasoma urophthalmus (Gunther): Aquaculture, v. 86, p. 409-416.

Falter, M.A., and Cech, J.J., 1991, Maximum pH tolerance of three Klamath Basin fishes: Copeia, v. 4, p. 1109-1111.

Foott, J.S., Stone, R., and Fogerty, R., 2007, Lack of disease response in juvenile Upper Klamath Lake suckers (age 0+) to adverse water-quality conditions: Investigational Report, California Nevada Fish Health Center, United States Fish and Wildlife Service, Anderson, California.

Galeotti, M., Beraldo, P., de Dominis, S., D’Angelo, L., Ballestrazzi, R., Musetti, R., Pizzoloito, S., and Pinosam, M., 2000, A preliminary histological and ultrastructural study of opercular anomalies in gilthead sea bream larvae (Sparus aurata): Fish Physiology and Biochemistry, v. 22, p.151-157. 
Hambright, K.D., 1991, Experimental analysis of prey selection by largemouth bass: role of predator mouth width and prey body depth: Transactions of the American Fisheries Society, v. 120, p. 500508.

Hendrixson, H.A., Burdick, S.M., and VanderKooi, S.P., 2007, Near-shore and offshore habitat use by endangered, juvenile Lost River and shortnose suckers in Upper Klamath Lake, Oregon: Annual Report 2004, Report of U.S. Geological Survey, Western Fisheries Research Center, Klamath Falls Field Station to Bureau of Reclamation, Mid-Pacific Region, Klamath Falls, Oregon.

Keeley, E.R, and Grant, J.W., 2001, Prey size of salmonid fishes in streams, lakes, and oceans: Canadian Journal of Fisheries and Aquatic Sciences, v. 58, p. 1122-1132.

Lindenberg, M.K., Hoilman, Gene., and Wood, T.M., 2008, Water-quality conditions in Upper Klamath Lake and Agency Lakes, Oregon, 2006: U.S. Geological Survey Scientific Investigations Report 2008-5201, 23 p. (Also available at http://pubs.usgs.gov/sir/2008/5201/.)

Lindesjoo, E., Thulin, J., Bengtsson, B.E., and Tjärnlund, U., 1994, Abnormalities of a gill cover bone, the operculum, in perch Perca fluviatilis from a pulp mill effluent area: Aquatic Toxicology, v. 28, p. 189-207.

Loftus, M.E., 2001, Assessment of potential water-quality stress to fish: Report by R2 Resources Consultants to Bureau of Indian Affairs, Portland, Oregon.

Markle, D.F., Cavalluzzi, M.R., and Simon, D.C., 2005, Morphology and taxonomy of Klamath Basin suckers (Catostomidae): Western North American Naturalist, v. 65, p. 473-489.

Markle, D.F., and Dunsmoor, L.K., 2007, Effects of habitat volume and fathead minnow introduction on larval survival of two endangered sucker species in Upper Klamath Lake, Oregon: Transactions of the American Fisheries Society, v. 136, p. 567-579.

Markle, D.F., and Simon, D.C., 1993, Preliminary studies of systematics and juvenile ecology of Upper Klamath Lake Suckers: Final Report: Oregon State University, Corvalis, Oregon.

McCune, B., and Grace, J.B., 2002, Analysis of ecological communities: MJM Software Design, Gleneden Beach, Oregon.

Morris, J.M., Snyder-Conn, E., Foott, J.S., Holt, R.A., Suedkamp, M.J., Lease, H.M., Clearwater, S.J., and Meyer, J.S., 2006, Survival of Lost River suckers (Deltistes luxatus) challenged with

Flavobacterium columnare during exposure to sublethal ammonia concentrations at $\mathrm{pH}$ 9.5: Archives of Environmental Contamination and Toxicology, v.50, p. 256-263.

Plunkett, S.R., and Snyder-Conn, E., 2000, Anomalies of larval and juvenile shortnose and Lost River suckers in Upper Klamath Lake, Oregon: U. S. Fish and Wildlife Service, Klamath Falls Fish and Wildlife Office, Klamath Falls, Oregon.

Saiki, M.K., Monda, D.P., and Bellerud, B.L., 1999, Lethal levels of selected water-quality variables to larval and juvenile Lost River and shortnose suckers: Environmental Pollution, v. 105, p. 37-44.

Simon, D.C., and Markle, D.F., 2008, Ecology of Upper Klamath Lake shortnose and Lost River suckers: Annual survey of abundance and distribution of age-0 shortnose and Lost River suckers in Upper Klamath Lake, 2007 Annual Report: Report of Oregon Cooperative Research Unit, Department of Fisheries and Wildlife, Oregon State University to U.S. Biological Resources Division, U.S. Geological Survey, Corvallis, Oregon and Klamath Project, Bureau of Reclamation, Klamath Falls, Oregon.

Terwilliger, M.R., Simon, D.C., and Markle, D.F., 2004, Larval and juvenile ecology of Upper Klamath Lake suckers, 1995-2003: Corvallis, Oreg., Oregon Cooperative Research Unit, Department of Fisheries and Wildlife, Oregon State University. 
The Nature Conservancy, 2009, Continuous physical water chemistry monitoring in water-quality conditions on the Williamson River Delta, Oregon: One Year Post-Restoration: The Nature Conservancy, Klamath Basin Field Office, Klamath Falls, Oregon.

The Nature Conservancy, 2010, 2009 water-quality conditions on the Williamson River Delta, Oregon: Two years post-restoration: The Nature Conservancy, Klamath Basin Field Office, Klamath Falls, Oregon.

Tringali, M.D., Ziemann, D.A., and Stuck, K.C., 2003, Preliminary aspects of genetic management for Pacific Threadfin Polydactylus sexfilis stock enhancement research in Hawaii in Nakamura, Y., McVey, J.P., Leber, K., Neidig, C., Fox, S., and Churchill, K. (eds.), Ecology of Aquaculture Species and Enhancement of Stocks: Proceedings of the Thirtieth U.S. - Japan Meeting on Aquaculture, Sarasota, Florida, December 3-4, 2001, UJNR Technical Report No. 30. Sarasota, FL: Mote Marine Laboratory, p. 55-74.

Truemper, H.A., and Lauer, T.E., 2005, Gape limitation and piscine prey size-selection by yellow perch in the extreme southern area of Lake Michigan, with emphasis on two exotic prey items: Journal of Fish Biology, v. 66, p. 135-149.

Klamath Lake, Oregon, 2002-04: U.S. Geological Survey Scientific Investigations Report 2006-5209, 49 p. (Also available at http://pubs.usgs.gov/sir/2006/5209/.) 


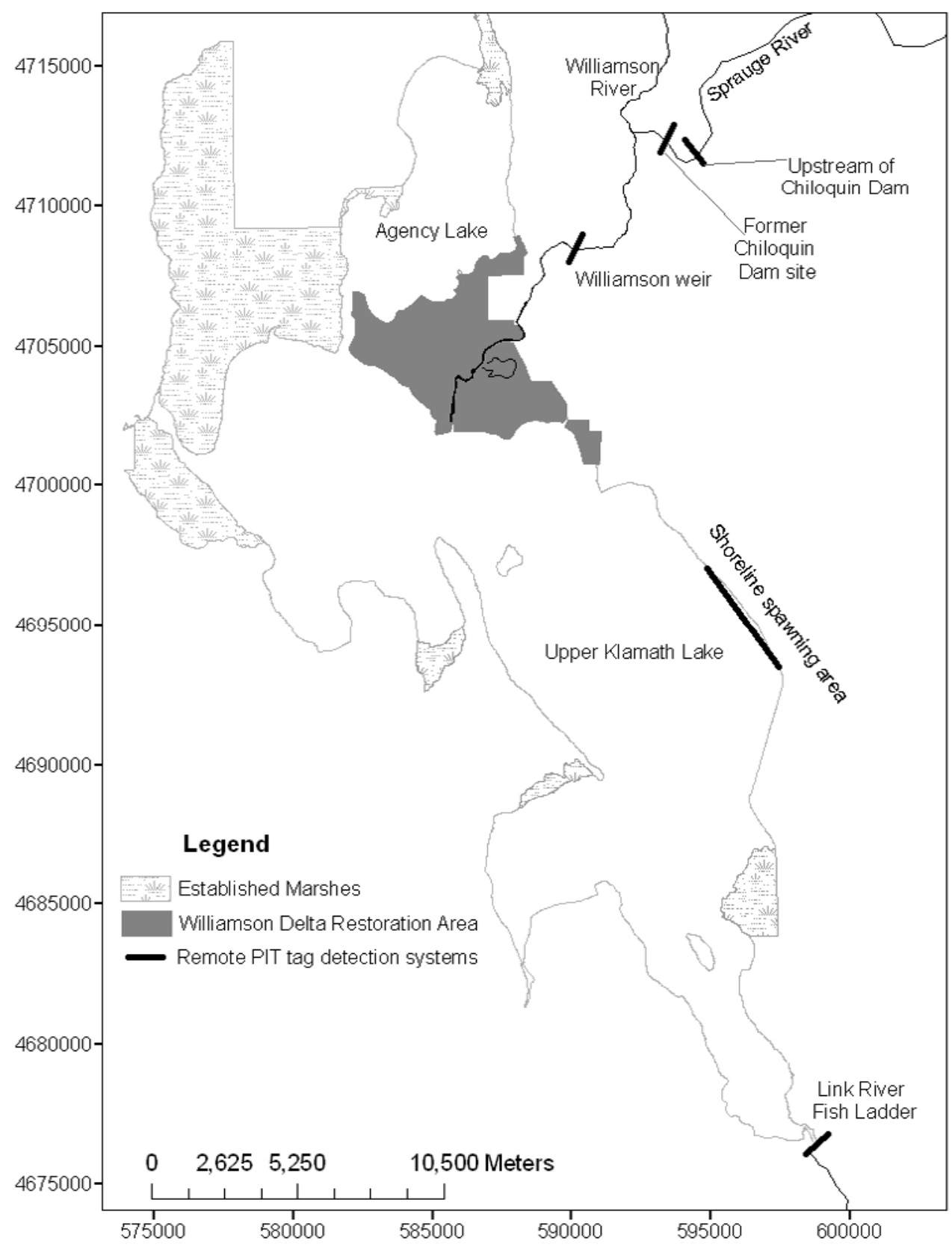

Figure 3.1. Locations of remote passive integrated transponder (PIT) detection systems operated during the spring and summer of 2009 in Upper Klamath Lake and adjacent rivers. Coordinate information is referenced to the Western Geographic System of 1984 (WGS84). The map coverage for the Williamson River Delta restoration area was provided by The Nature Conservancy. 


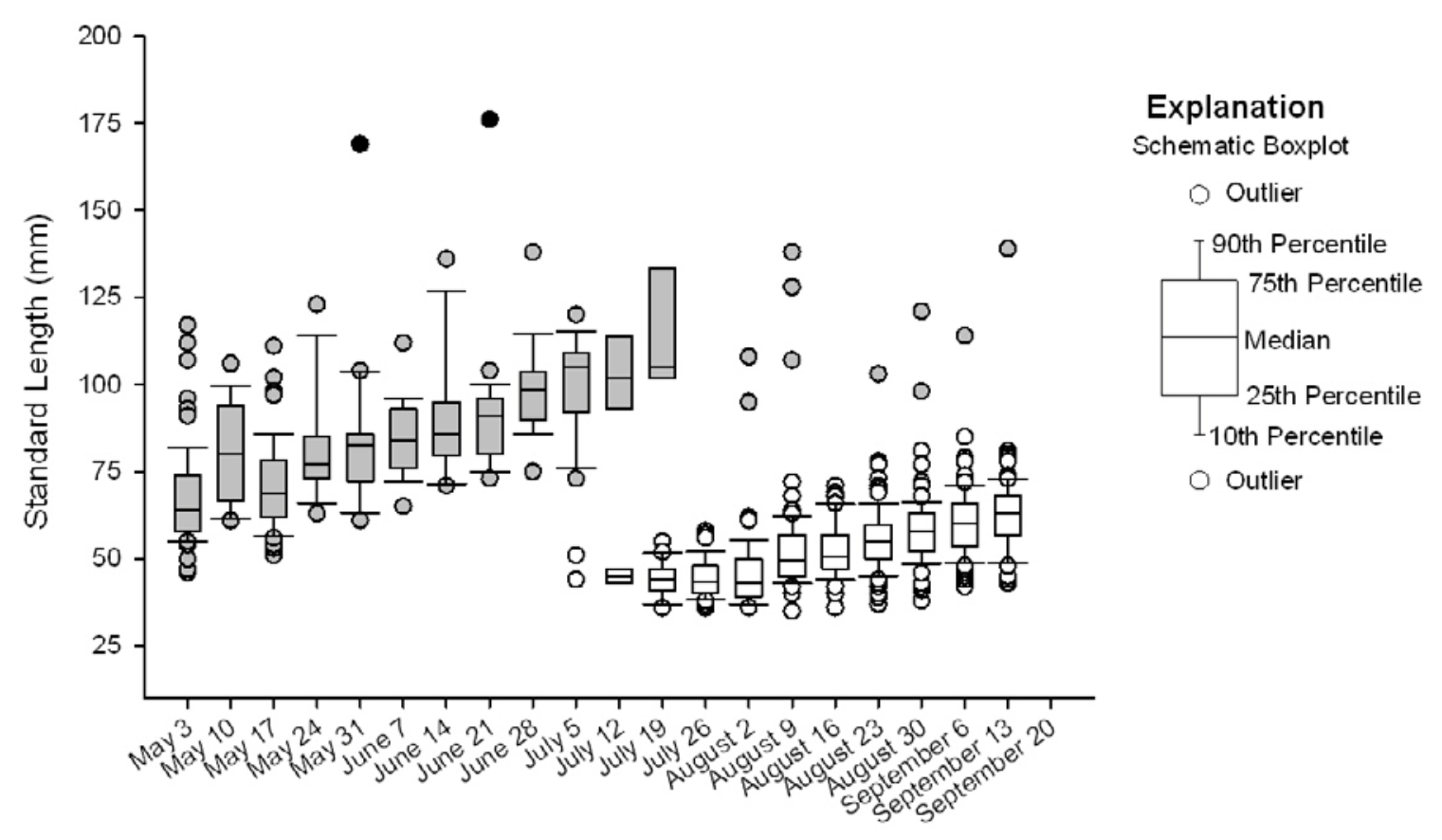

Figure 3.2. Length of juvenile suckers collected in trap nets set in the Williamson River Delta and southern Agency Lake, Oregon, between May 4 and September 18, 2009. Two or three age classes are shown, juvenile age-0 suckers are shown in white, age-1 suckers in gray, and suckers suspected to be age-2 or older are shown in black. Dates shown are for the Sunday that starts each week. 
shortnose suckers

Lost River suckers
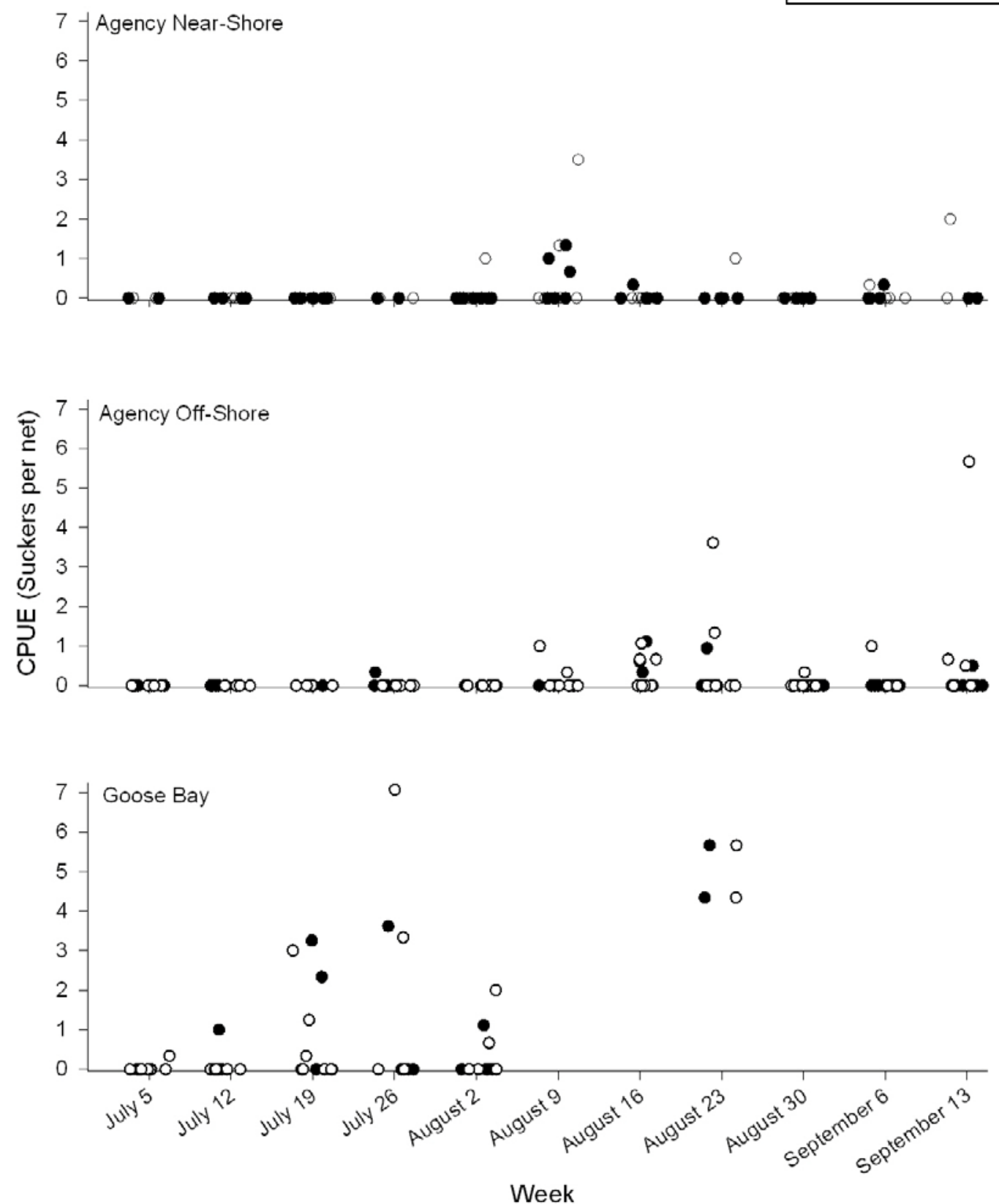

Figure 3.3. Catch per unit effort (CPUE; suckers per net) for age-0 shortnose (black dots) and Lost River (white dots) suckers caught in the Goose Bay Unit of the Williamson River Delta and in near-shore and off-shore areas of southern Agency Lake (fig. 1.1), between July 5 and September 18, 2009. Data are randomly jittered along the xaxis to improve the display. Dates shown are for the Sunday that started each week. 

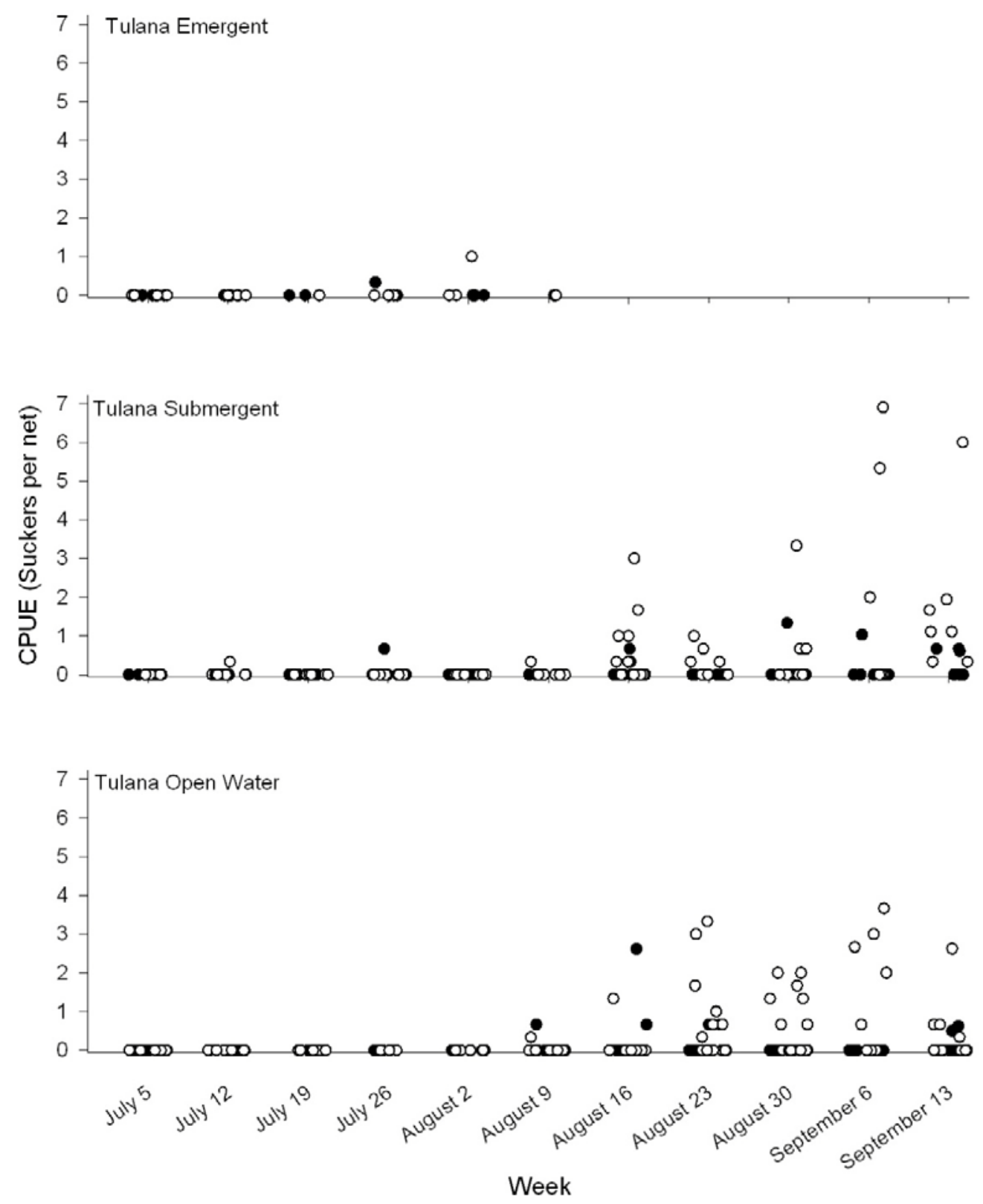

Figure 3.4. Catch per unit effort (CPUE; suckers per net) for age-0 shortnose (black dots) and Lost River (white dots) suckers caught in the Tulana Emergent, Tulana Submergent, and Tulana Open Water sampling strata (fig. 1.1) located in the Williamson River Delta between July 5 and September 18, 2009. Data are randomly jittered along the $\mathrm{x}$-axis to improve the display. Dates shown are for the Sunday that started each week. 

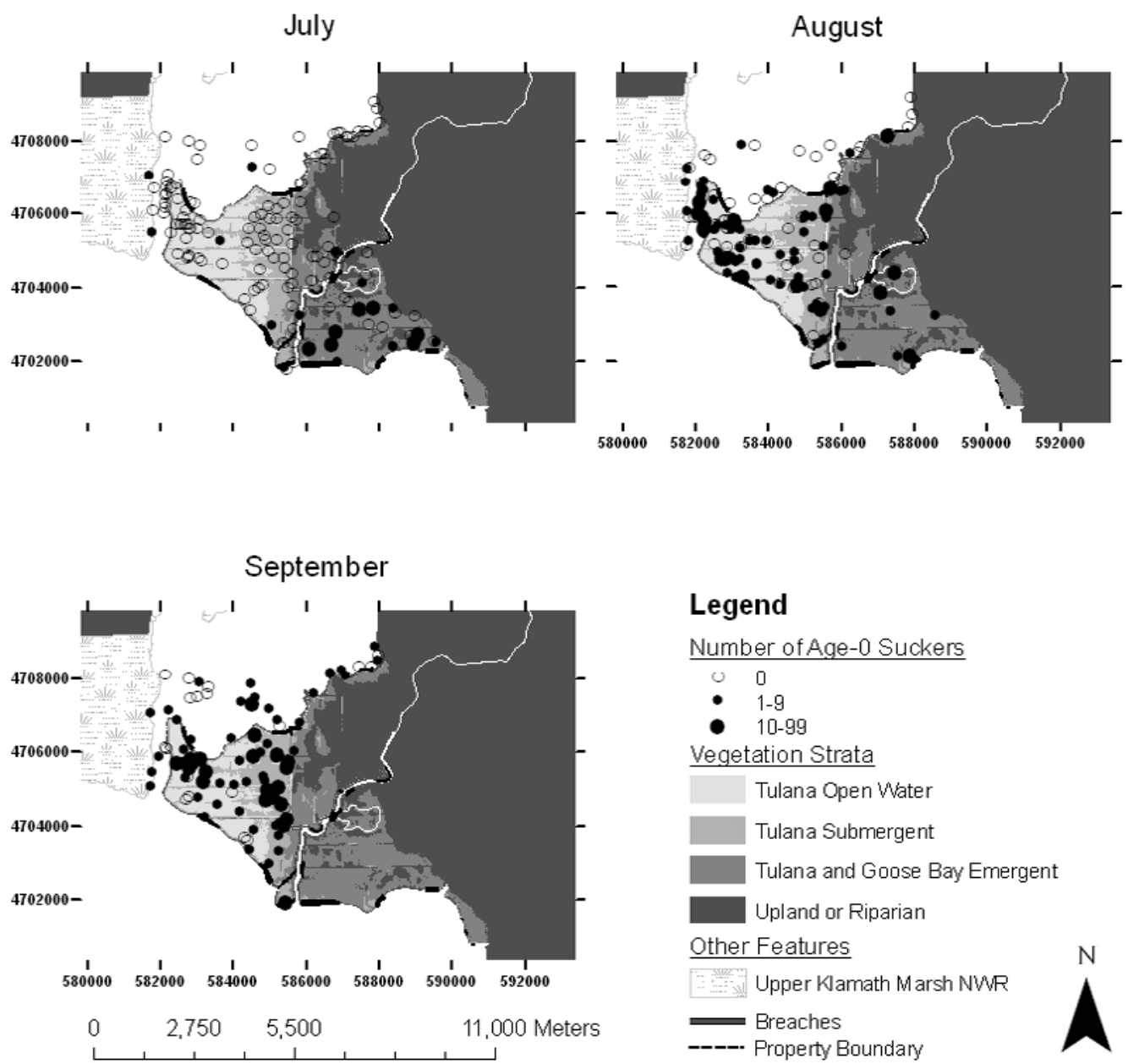

Figure 3.5. Sampling locations and sites where age-0 suckers were captured in trap net sampling in the Williamson River Delta and southern Agency Lake by month in 2009. Sampling strata and surrounding environments (shown in shades of gray) are based on predicted vegetation types expected to develop in below average water years. Map layers for vegetation within the delta were provided courtesy of The Nature Conservancy. Coordinate information is referenced to the Western Geographic System of 1984 (WGS84). 

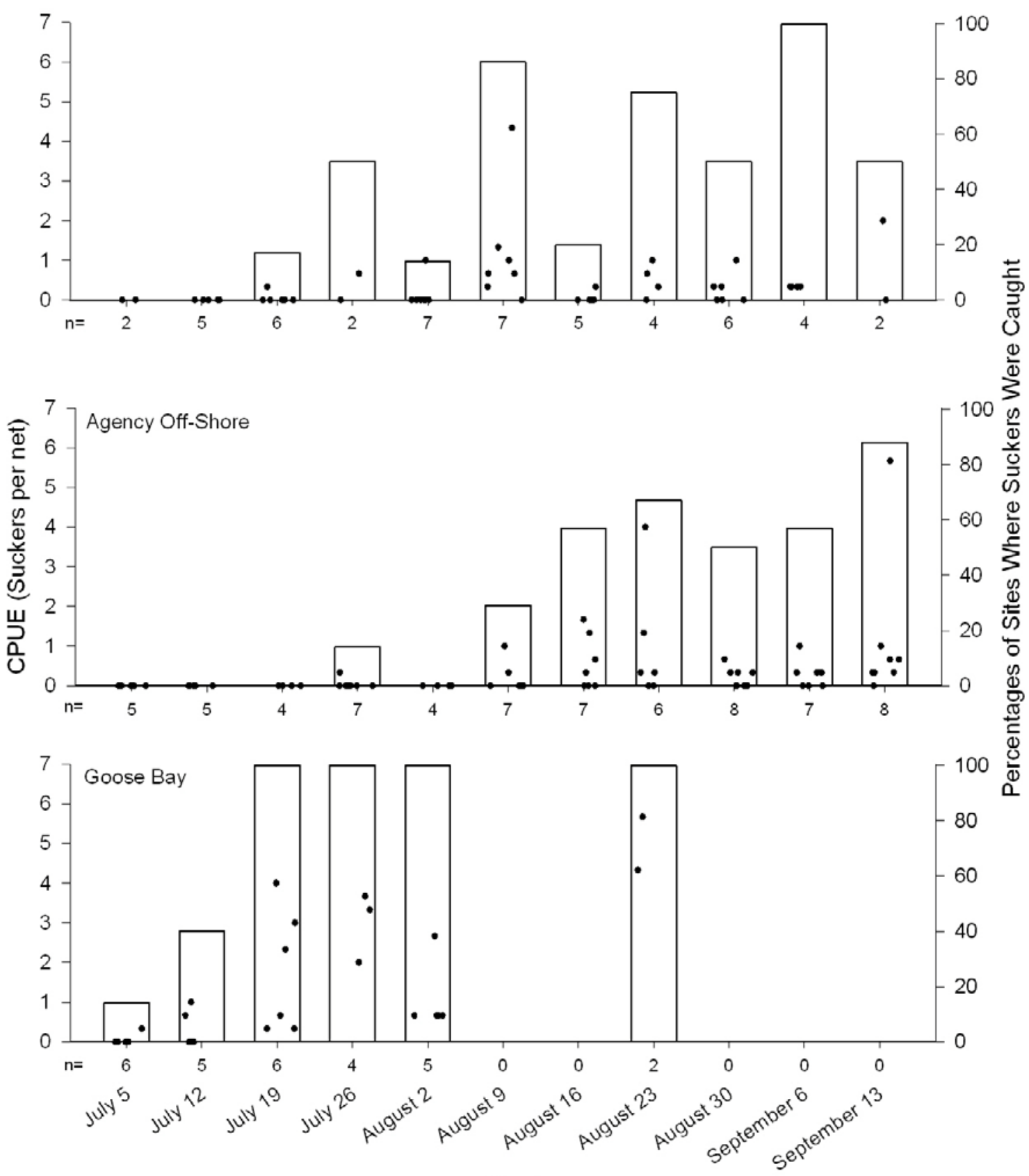

Week

Figure 3.6. Catch per unit effort (CPUE; suckers per net; black dots) for age-0 suckers caught in the Goose Bay Unit of the Williamson River Delta and in near-shore and off-shore areas of southern Agency Lake (fig. 1.1), between July 5 and September 18, 2009. CPUE values were randomly jittered along the $x$-axis to improve the display. The percentages of sites each week at which least one sucker was caught are shown with bar plots. The numbers of sites sampled each week are given below the x-axis. Dates shown are for the Sunday at the start of each week. 

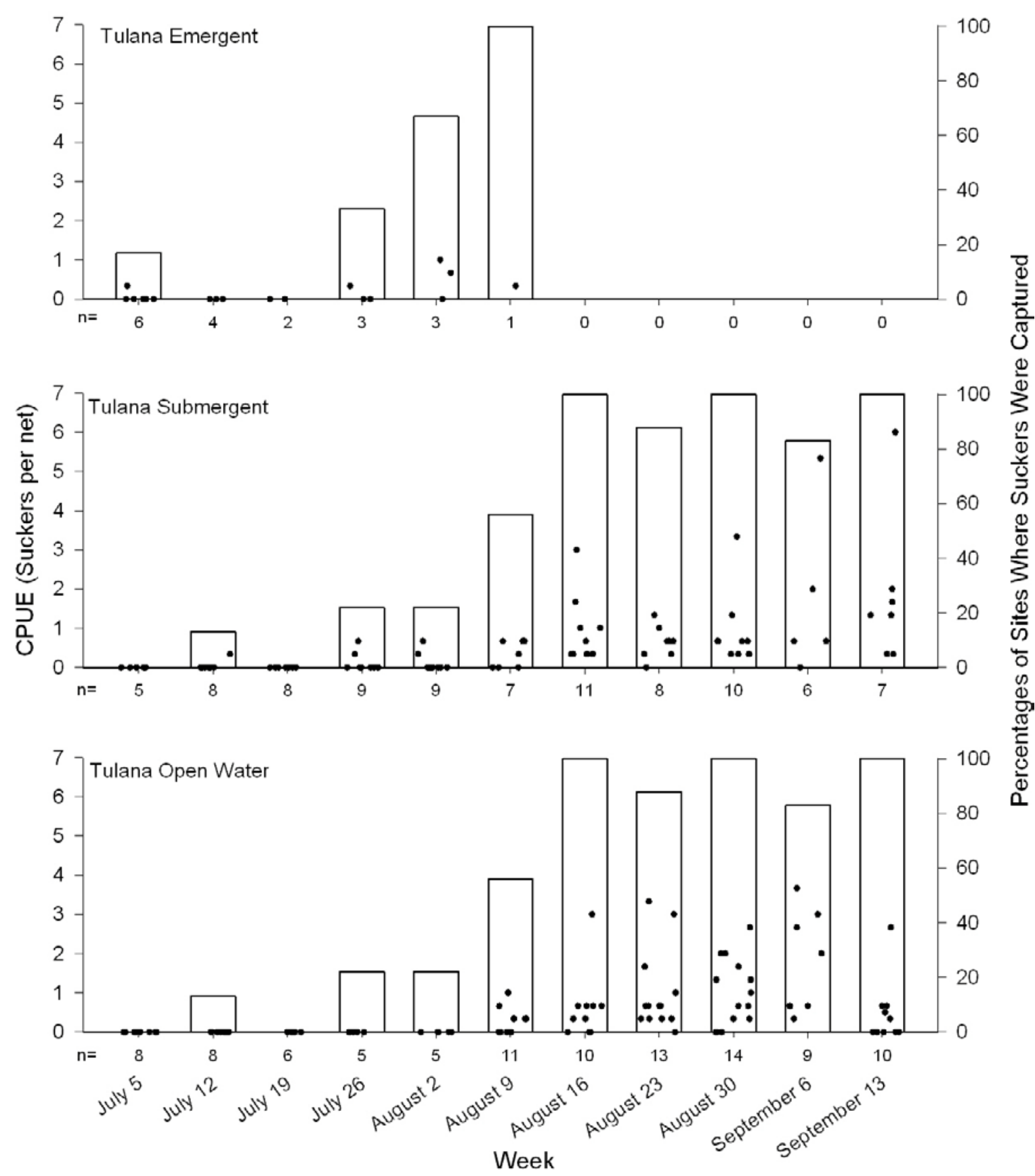

Figure 3.7. Catch per unit effort (CPUE; suckers per net) for age-0 suckers caught in the Tulana Emergent, Tulana Submergent, and Tulana Open Water sampling strata (fig. 1.1) located in the Williamson River Delta Preserve between July 5 and September 18, 2009. CPUE values were randomly jittered along the $x$-axis to improve the display. The percentages of sites each week at which least one sucker was caught are shown with bar plots. The numbers of sites sampled each week are given below the $\mathrm{x}$-axis. Dates shown are for the Sunday at the start of each week. 


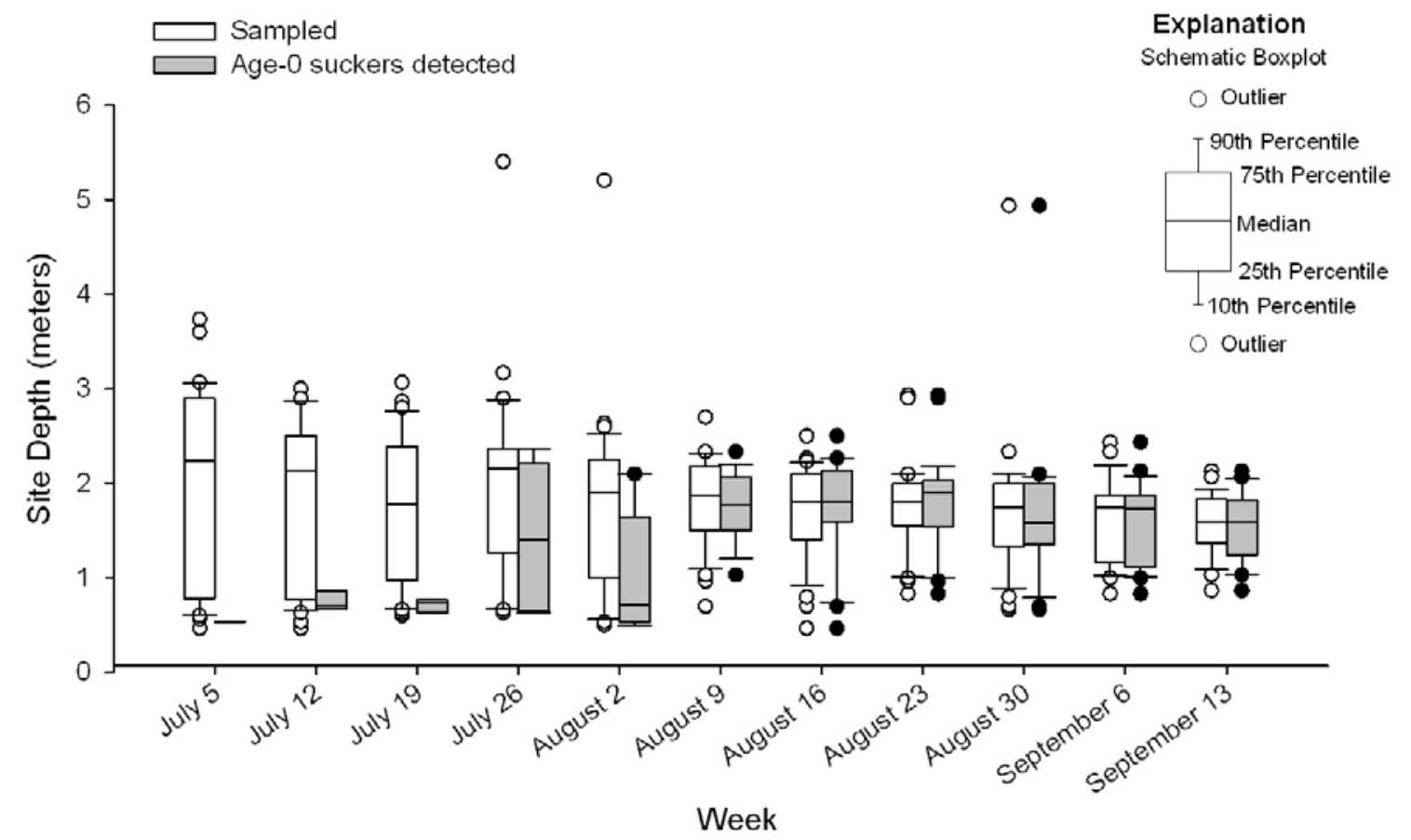

Figure 3.8. Depth at sites sampled (white) and sites where age- 0 suckers were captured in trap nets (gray) each week between July 5 and September 18, 2009 in the Williamson River Delta and southern Agency Lake, Oregon. Dates shown are for the Sunday at the start of each week. 
Explanation

Schematic Boxplot

Agency Near-Shore

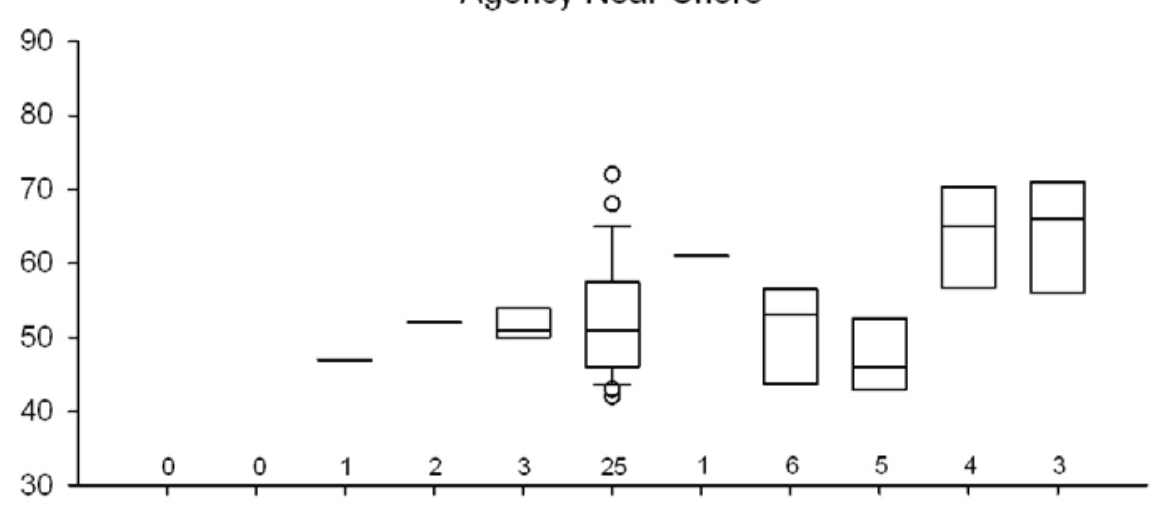

Agency Off-Shore
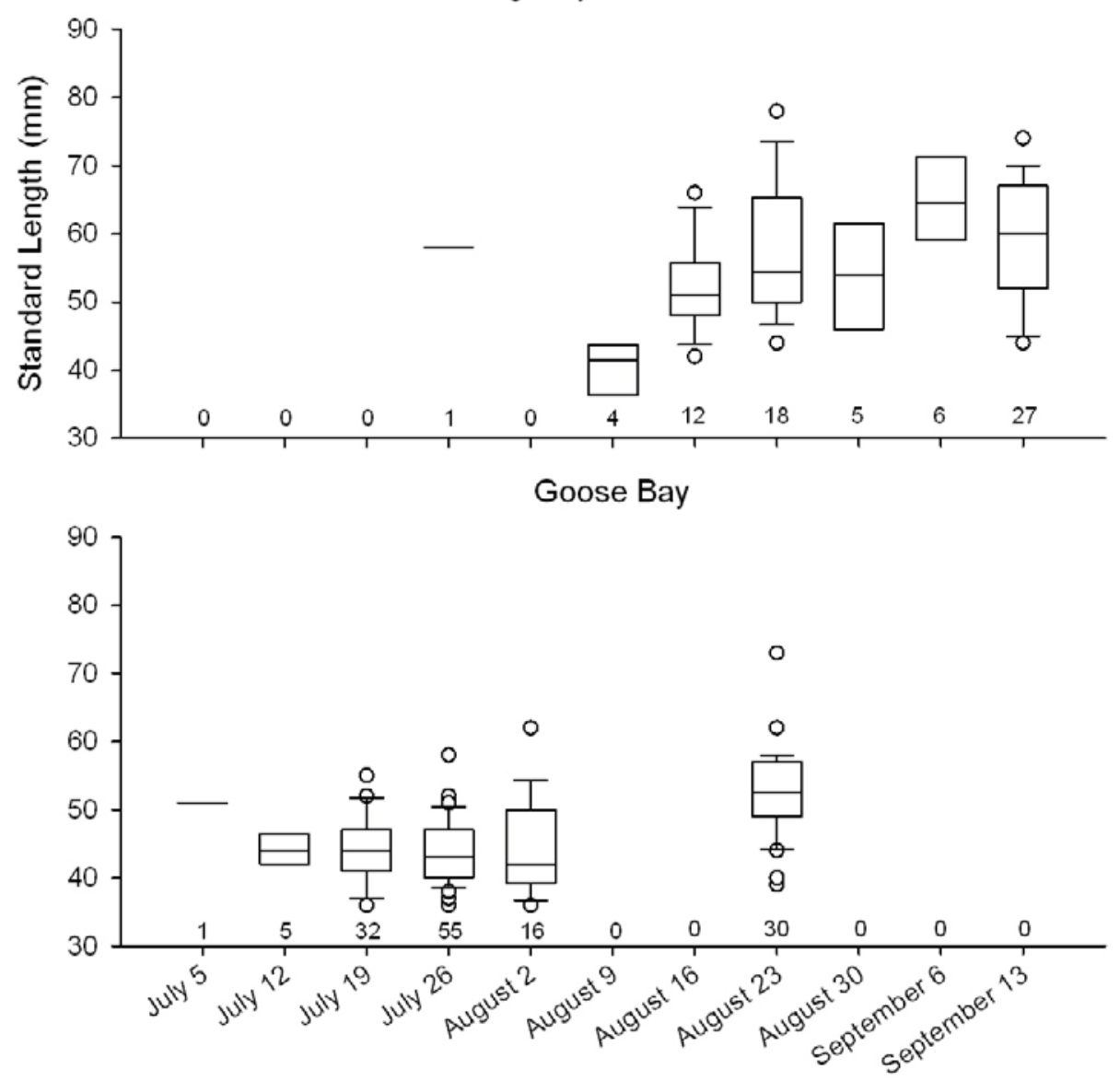

Figure 3.9. Standard length $(\mathrm{mm})$ of age-0 suckers caught in trap net sampling in the Goose Bay Unit of the Williamson River Delta and in near-shore and off-shore areas of southern Agency Lake (fig. 1.1), between July 5 and September 18, 2009. The numbers of age-0 suckers caught each week in each stratum, and used in the creation of each box plot are given along the x-axis. Dates shown are for the Sunday at the start of each week. 
Tulana Emergent
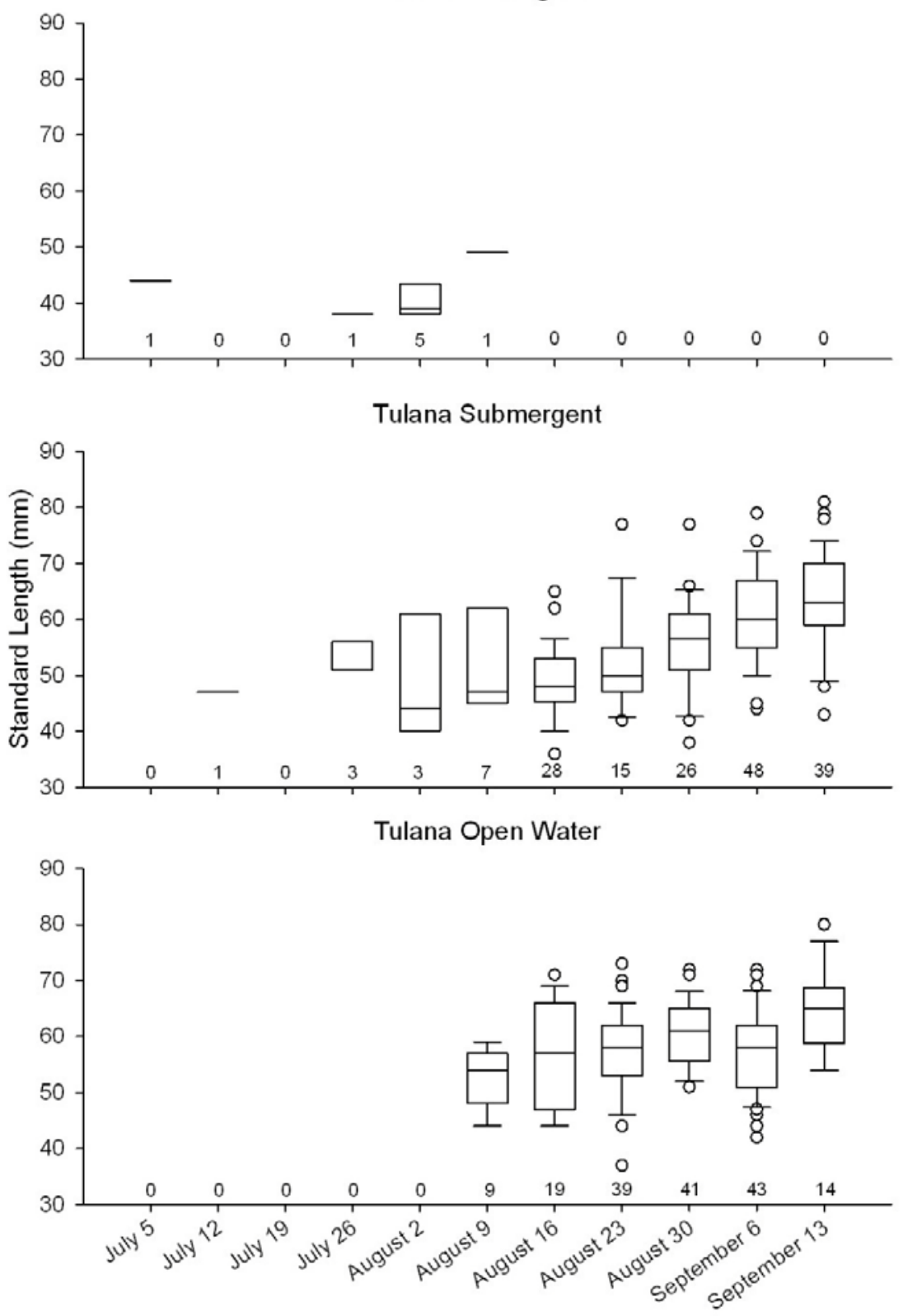

Figure 3.10. Standard length $(\mathrm{mm})$ of age-0 suckers caught in trap net sampling in the Tulana Emergent, Tulana Submergent, and Tulana Open Water sampling strata (fig. 1.1) located in the Williamson River Delta between July 5 and September 18, 2009. The numbers of age-0 suckers caught each week in each stratum, and used in the creation of each box plot are given along the x-axis. Dates shown are for the Sunday at the start of each week. 


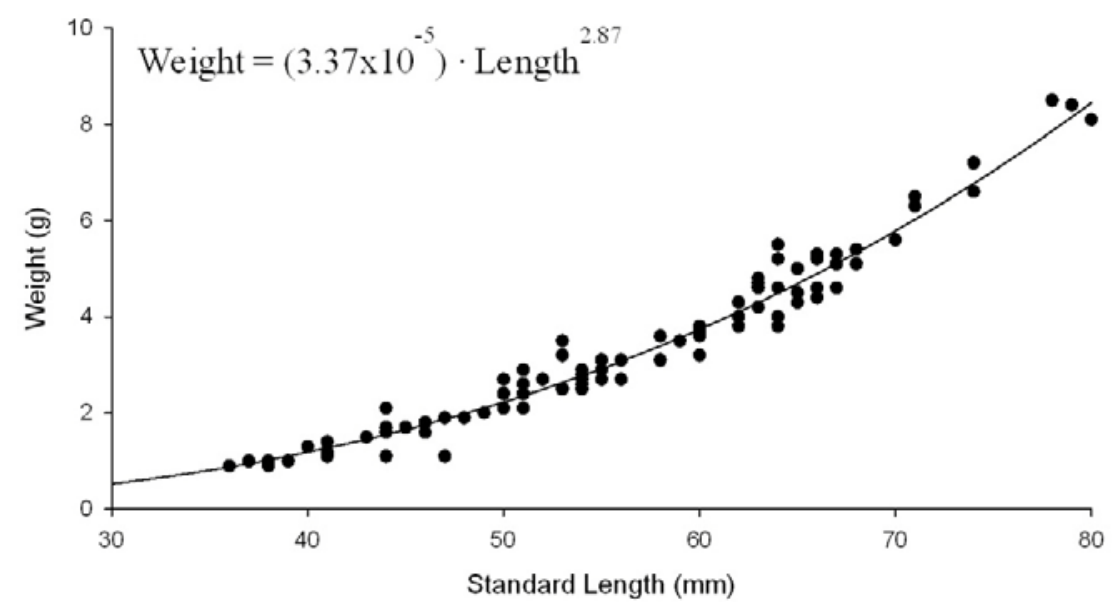

Figure 3.11. Relation between weight $(\mathrm{g})$ and standard length $(\mathrm{mm})$ of sacrificed juvenile age-0 Lost River (top) and shortnose (bottom) suckers captured by trap net in the Williamson River Delta or southern Agency Lake, between July 5 and September 18, 2009. 

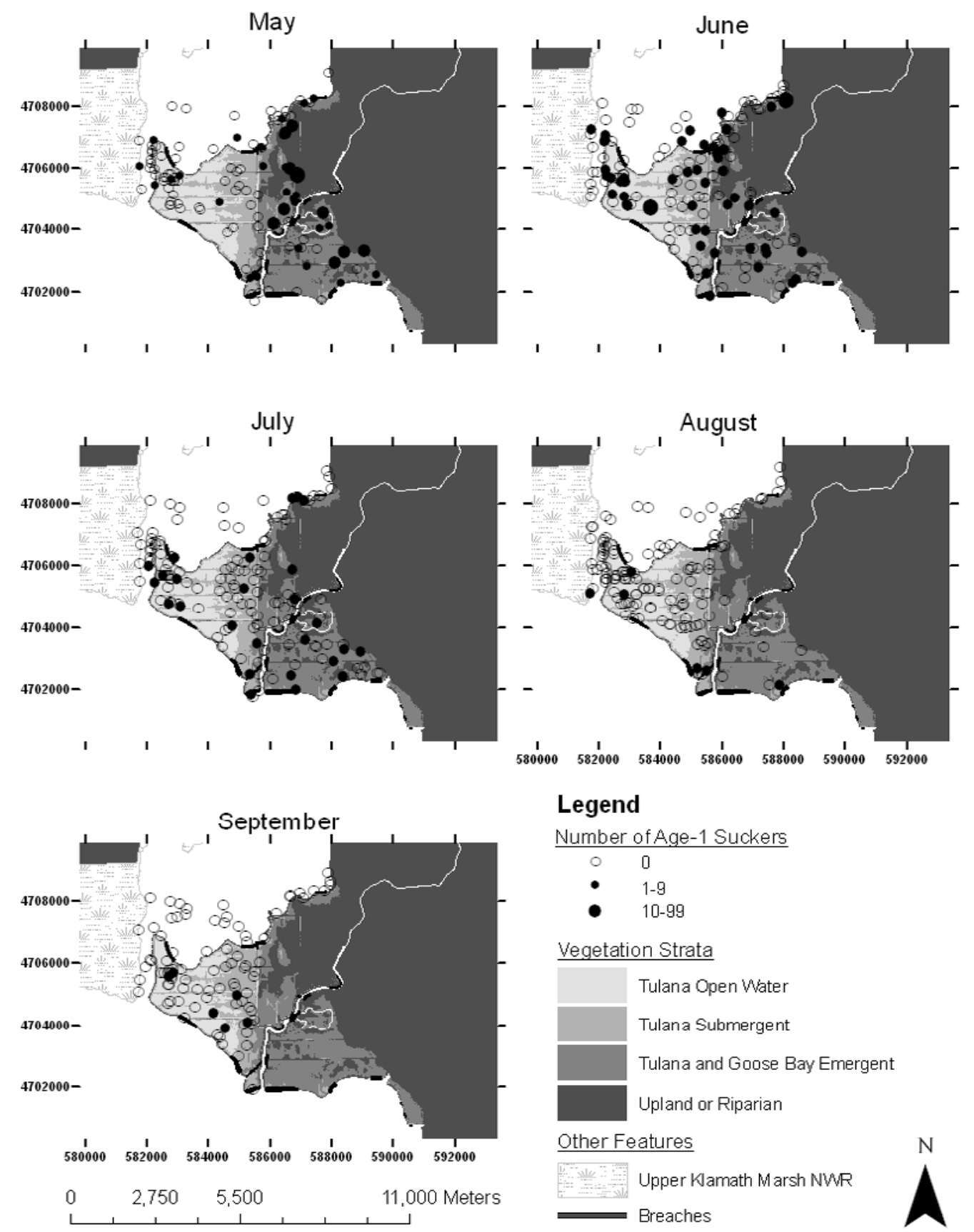

\section{Legend}

Number of Age-1 Suckers

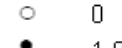

- $1-9$

- 10-99

Vegetation Strata

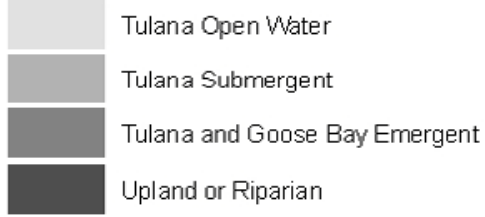

Other Features

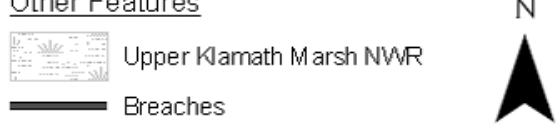

Figure 3.12. Sample locations and sites where age-1 suckers were captured in trap net sampling in the Williamson River Delta and southern Agency Lake by month in 2009. Sampling strata and surrounding environments (shown in shades of gray) are based on predicted vegetation types expected to develop in below average water years. Map layers for vegetation within the delta were provided courtesy of The Nature Conservancy. Coordinate information is referenced to the Western Geographic System of 1984 (WGS84). 

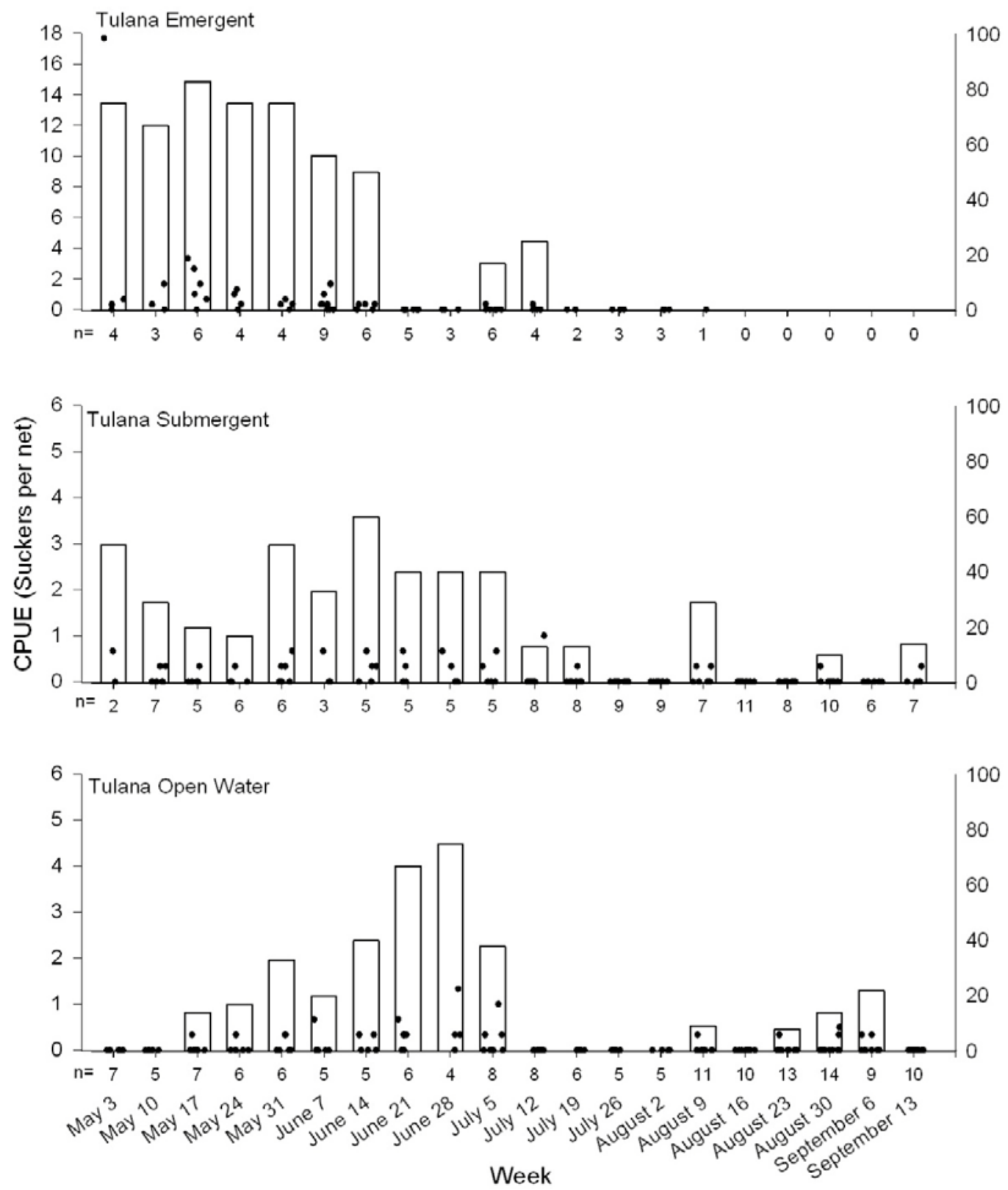

Figure 3.13. Catch per unit effort (CPUE; suckers per net) for age-1 suckers caught in trap net sampling in the Tulana Emergent, Tulana Submergent, and Tulana Open Water sampling strata (fig. 1.1) located in the Williamson River Delta between May 4 and September 18, 2009. CPUE values were randomly jittered along the x-axis to improve the display. The percentages of sites each week at which least one sucker was caught are shown with bar plots. The numbers of sites sampled each week are given below the x-axis. Dates shown are for the Sunday at the start of each week. Notice the difference in the $y$-axis scale on the Tulana Emergent plot compared to the two other plots. 

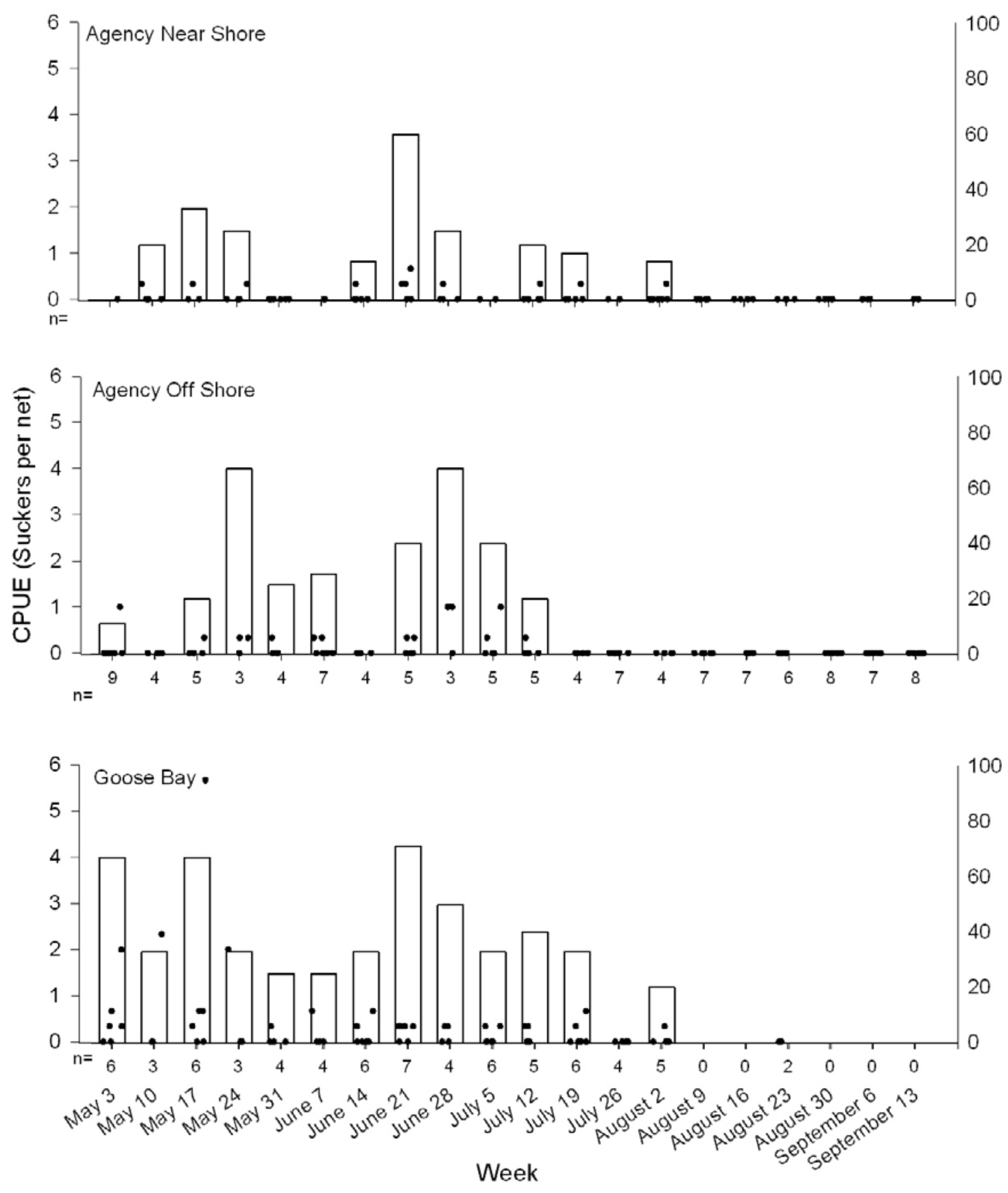

Figure 3.14. Catch per unit effort (suckers per net; black dots) for age-1 suckers caught in the Goose Bay Unit of the Williamson River Delta and in near-shore and off-shore areas of southern Agency Lake (fig. 1.1), between May 4 and September 18, 2009. CPUE values were randomly jittered along the $x$-axis to improve the display. The percentages of sites each week at which least one sucker was caught are shown with open bars. The numbers of sites sampled each week are given below the x-axis. Dates shown are for the Sunday at the start of each week. 


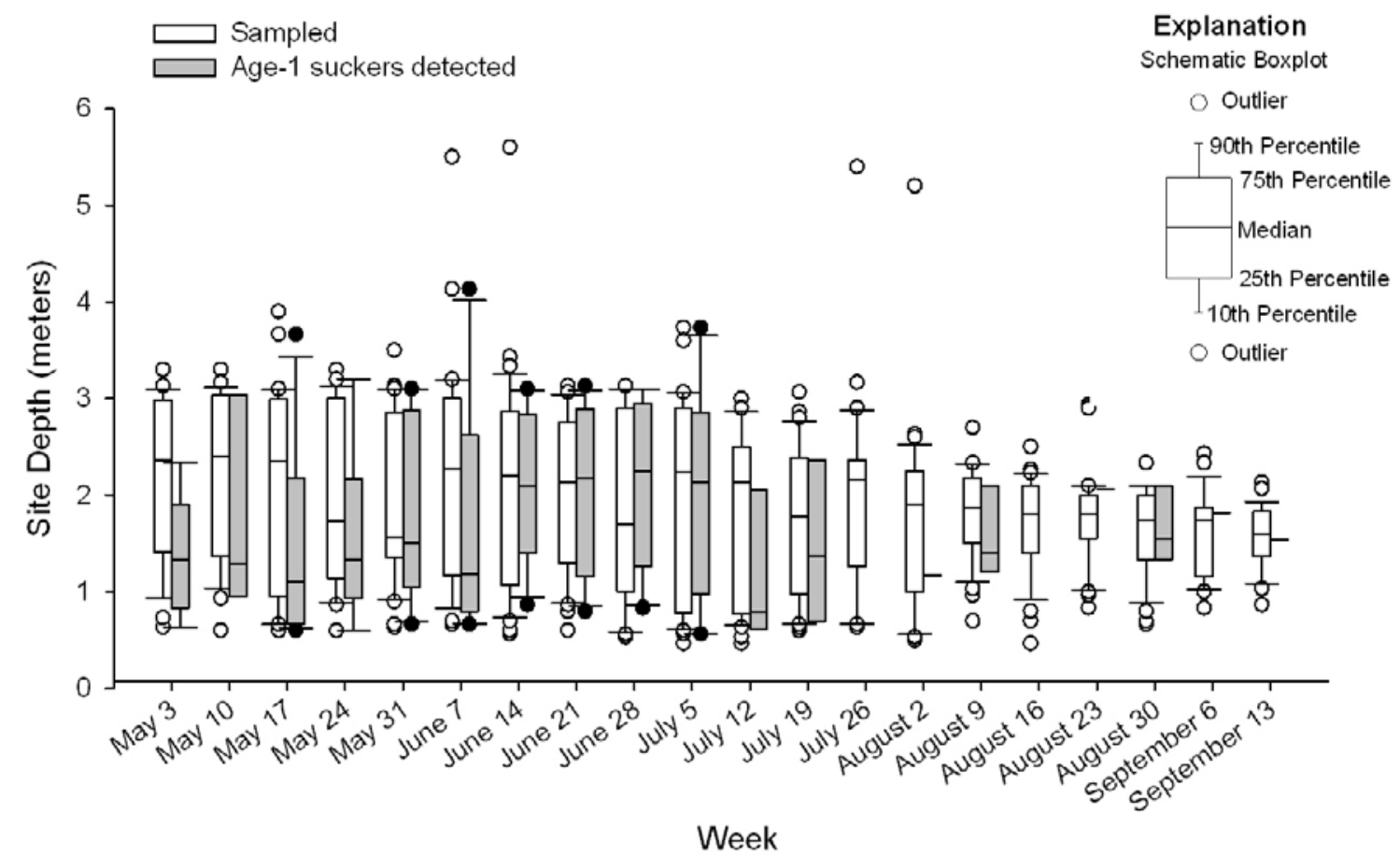

Figure 3.15. Depth at sites sampled (white) and sites where age-1 suckers were captured in trap nets (grey) each week, between May 4 and September 18, 2009 in the Williamson River Delta and southern Agency Lake, Oregon. Dates shown are for the Sunday that starts each week.

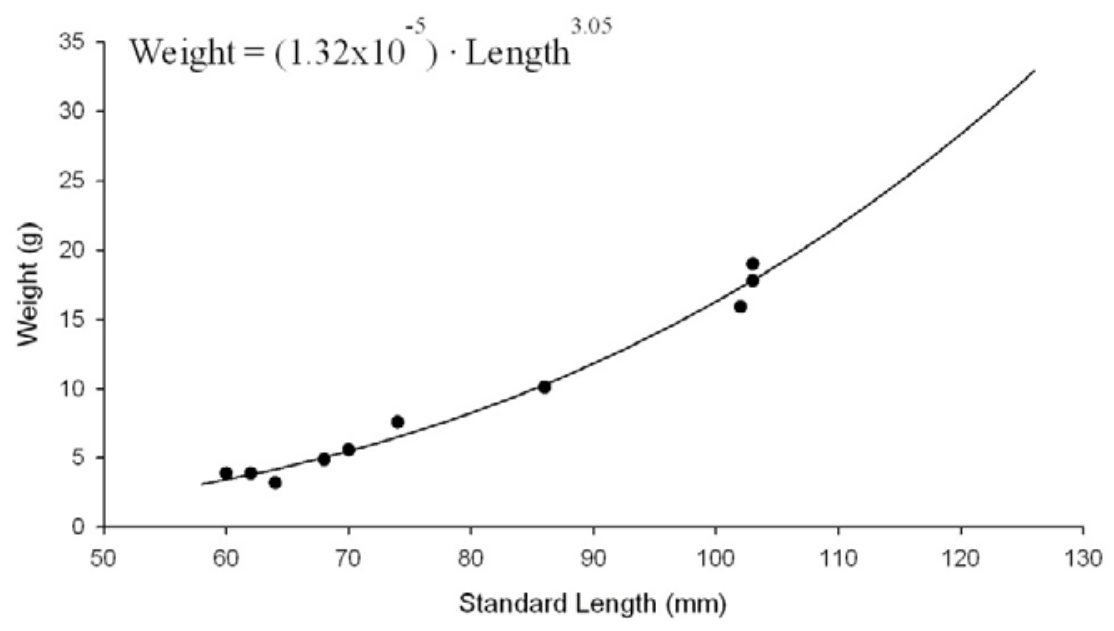

Figure 3.16. Relation between weight $(\mathrm{g})$ and standard length $(\mathrm{mm})$ of sacrificed age-1 suckers captured by trap nets in the Williamson River Delta or southern Agency Lake, between May 4 and September 18, 2009. 


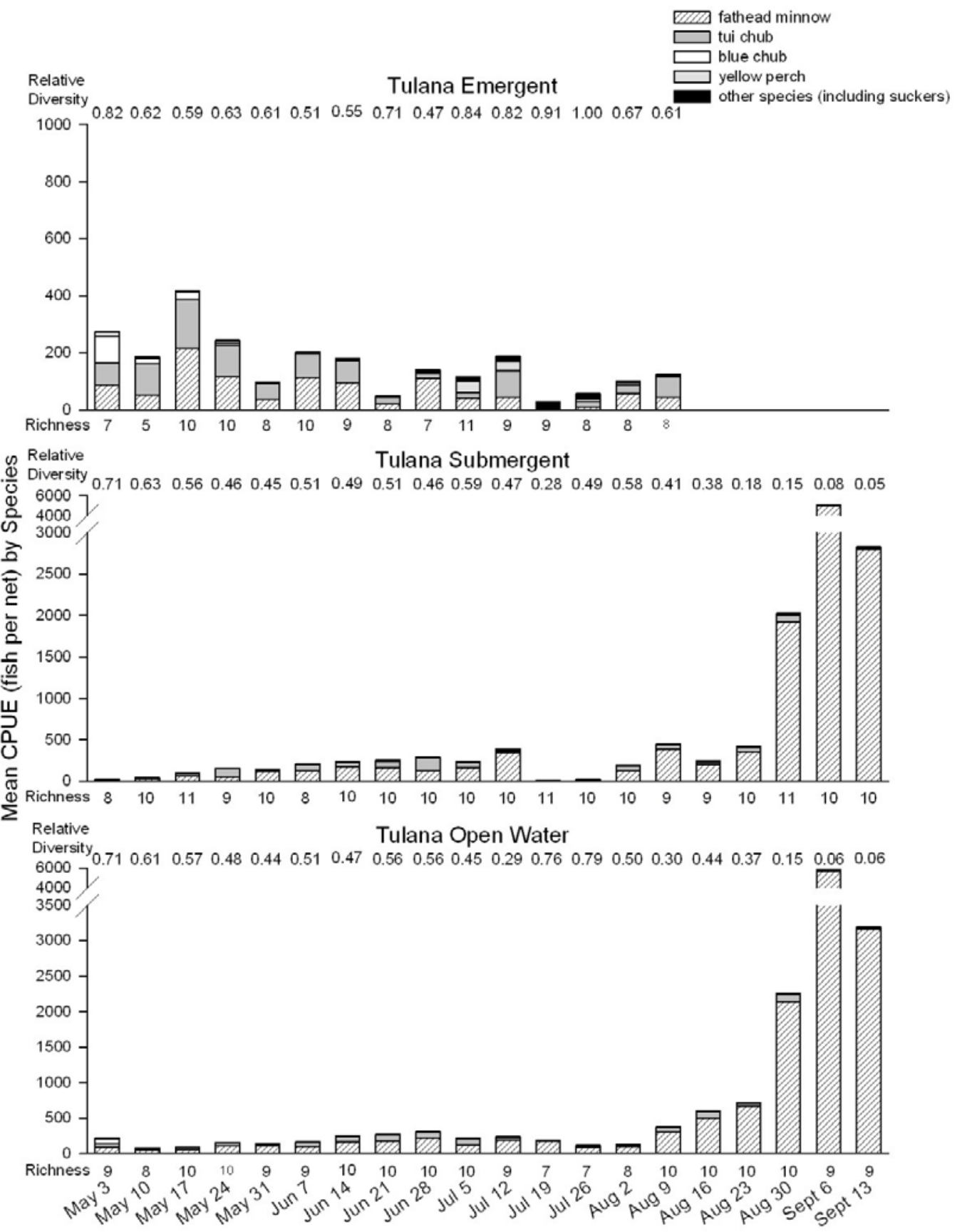

Figure 3.17. Number of juvenile or small adult fish caught per overnight trap net sample, by week and species. Nets were set in the Tulana Emergent, Tulana Submergent, and Tulana Open Water sampling strata (fig. 1.1) located in the Williamson River Delta between May 4 and September 18, 2009. Notice the difference in the y-axis scale in the Tulana Emergent plot, compared to the other two plots. 


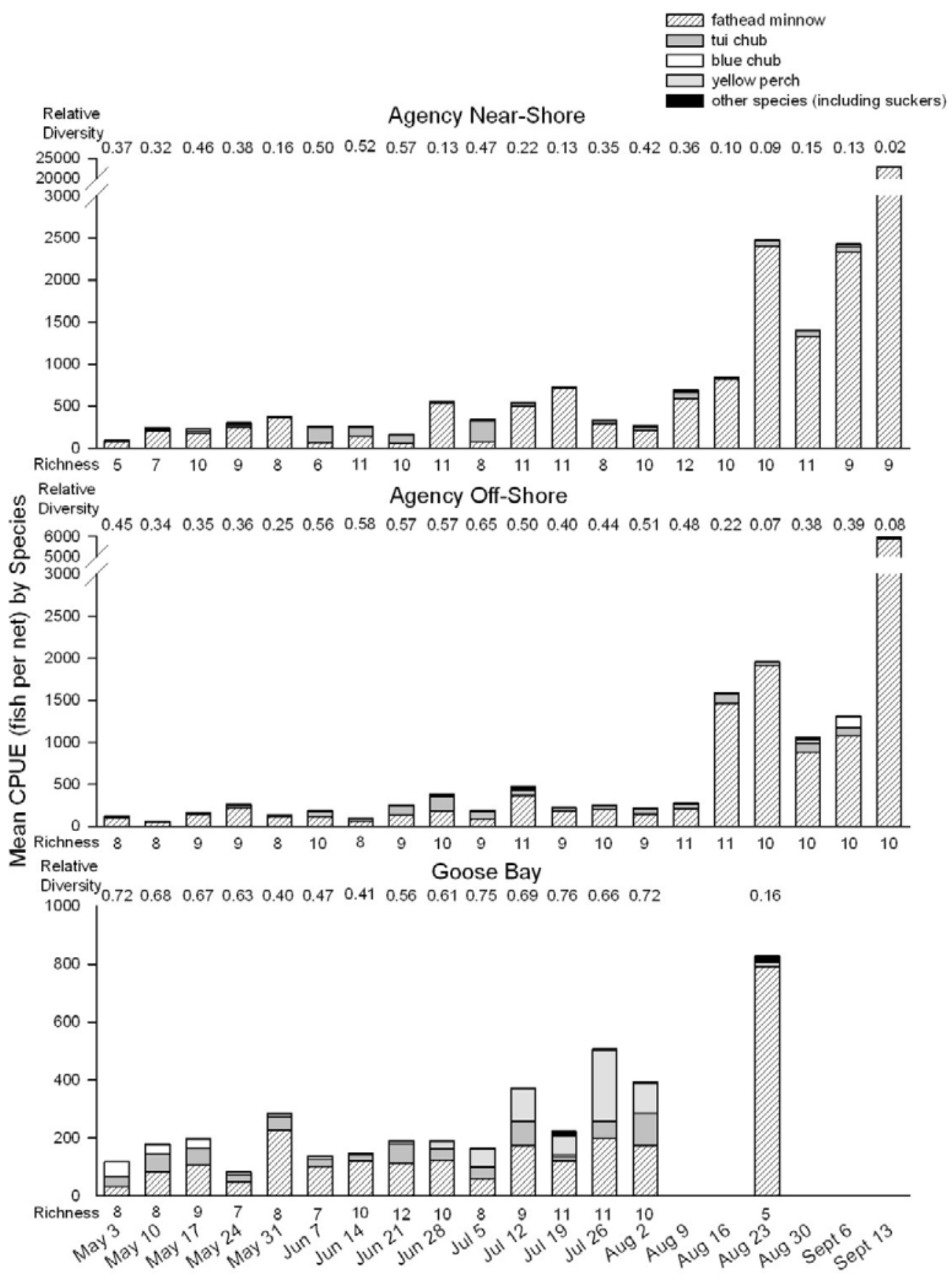

Figure 3.18. Number of juvenile or small adult fish caught per overnight trap net sample, by week and species. Nets were set in the Goose Bay Unit of the Williamson River Delta Preserve and in near-shore and off-shore areas of southern Agency Lake (fig. 1.1), between May 4 and September 18, 2009. Notice the difference in the y-axis scale for all three plots. 


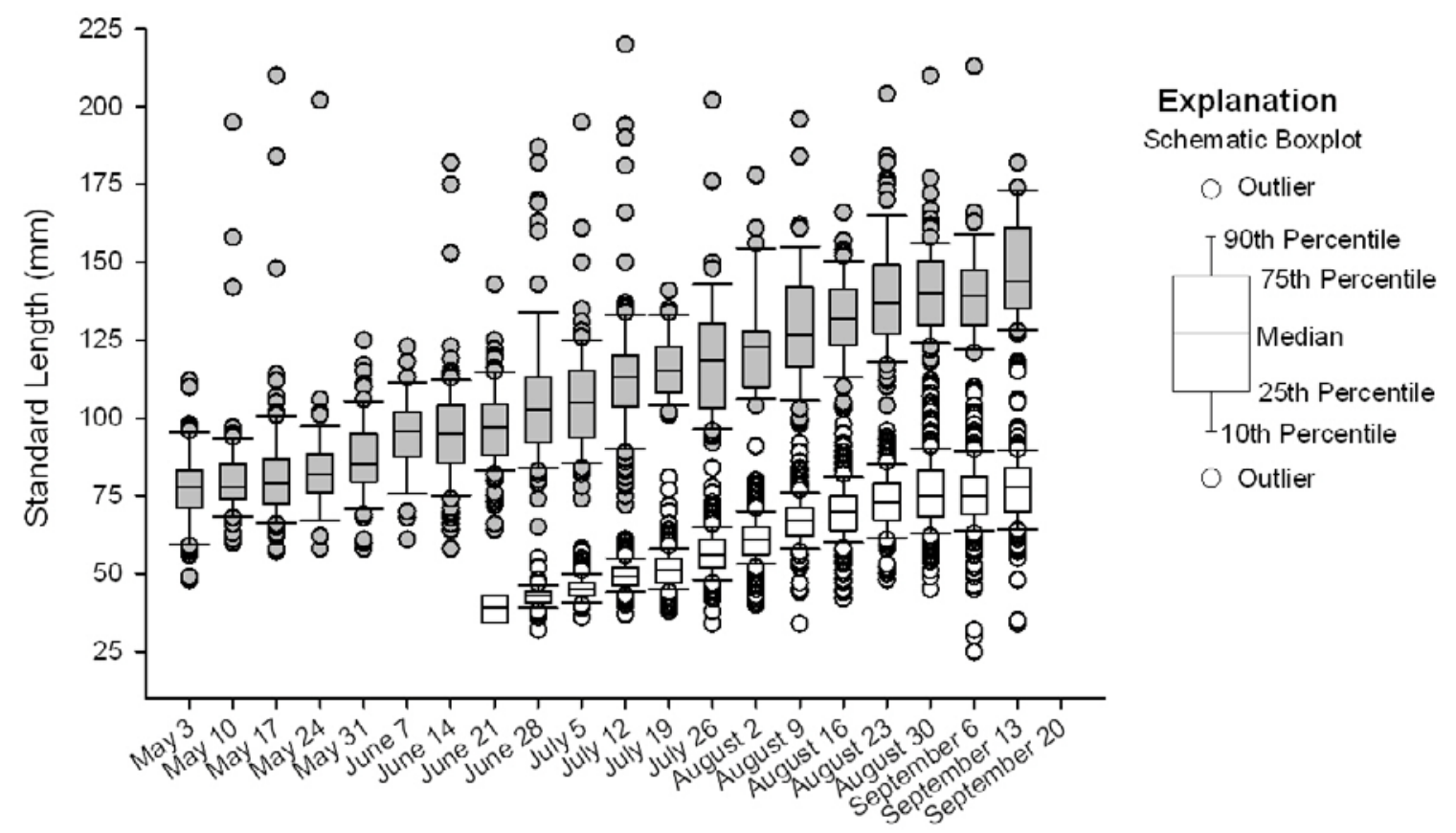

Figure 3.19. Length of yellow perch collected in traps nets set in the Williamson River Delta and southern Agency Lake, Oregon, between May 4 and September 18, 2009. At least two age classes are shown, juvenile age-0 yellow perch are shown in white and age-1 or older yellow perch suckers in grey. Dates shown are for the Sunday that starts each week. 

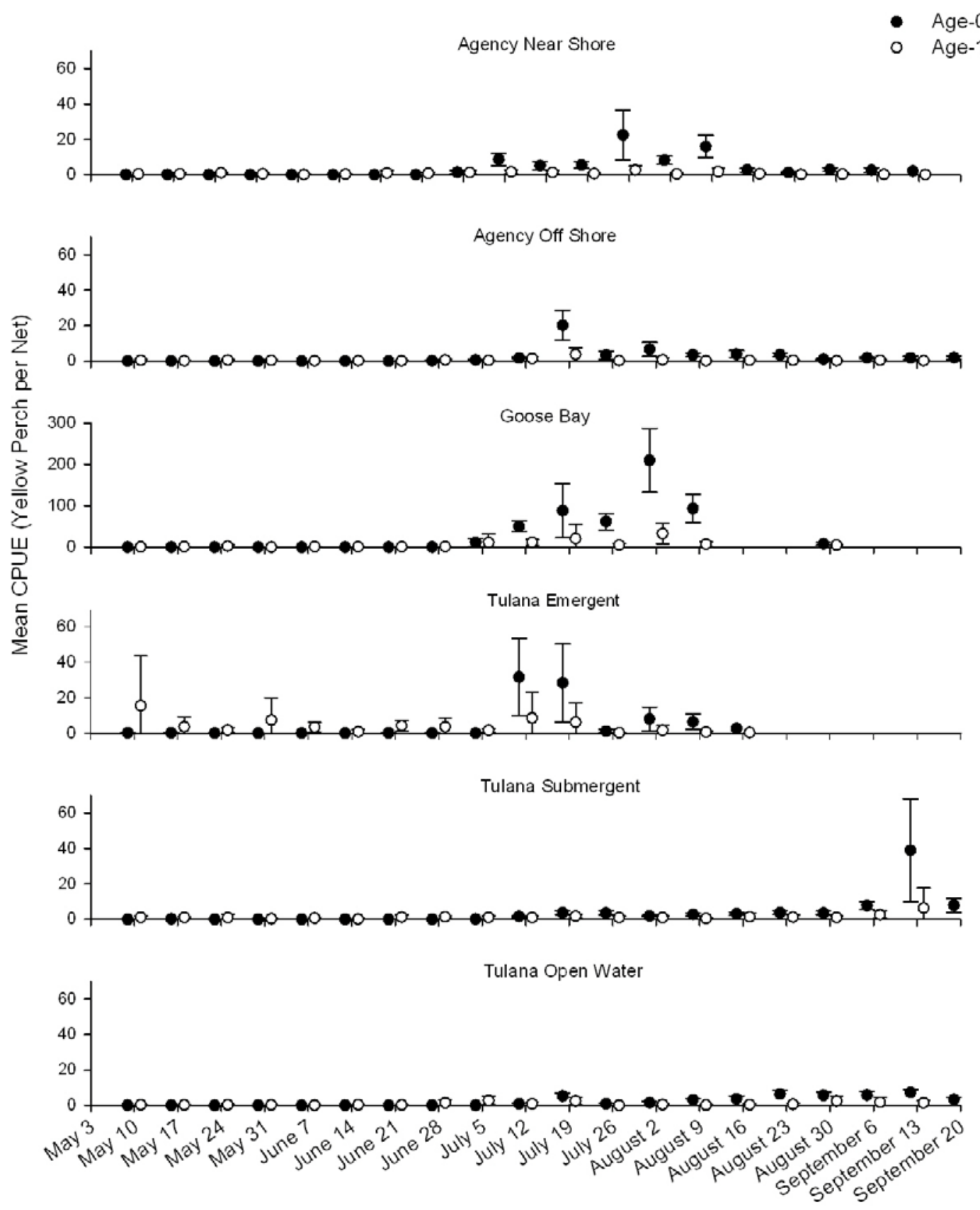

Figure 3.20. Mean ( \pm SD) weekly catch per unit effort (yellow perch per net) for age-0 and age-1 or older yellow perch caught in trap nets set overnight in four strata in the Williamson River Delta and two strata in southern Agency Lake, Oregon between May 4 and September 18, 2009 (fig. 1.1). Age-0 yellow perch are shown in black and age-1 or older yellow perch are shown in white. Notice the difference in the y-axis in the Goose Bay plot, when compared to the other plots. Dates shown are for the Sunday at the start of each week. 
Table 3.1. Number of sites sampled in six strata in the Williamson River Delta and southern Agency Lake.

\begin{tabular}{lc}
\hline \multicolumn{1}{c}{ Strata } & \# Sites \\
\hline Agency Near Shore & 87 \\
Agency Off Shore & 112 \\
Goose Bay & 72 \\
Tulana Emergent & 64 \\
Tulana Open Water & 150 \\
Tulana Submergent & 132 \\
\hline
\end{tabular}

Table 3.2. Median relative weight $(W r)$ of age-0 Lost River and shortnose suckers in six strata sampled in the Williamson River Delta and southern Agency Lake.

[See figure 1.2 for location of sampling strata. Relative weight was calculated by fitting a power curve to species specific length-weight data for age-0 suckers and dividing the individual weight of each fish by the weight predicted by the curve (Anderson and Neumann, 1996). The numbers (n) of fish in each stratum used to calculate median relative weights are given. Relative weights of 100 indicate typical condition for fish captured in our study. Therefore, relative weights greater than 100 indicated fish in relatively good condition and less than 100 indicated fish in relatively poor condition, when compared to the other fish of the same species captured in our study]

\begin{tabular}{|c|c|c|c|c|}
\hline \multirow[b]{2}{*}{ Stratum } & \multicolumn{2}{|c|}{ Lost River sucker } & \multicolumn{2}{|c|}{ shortnose sucker } \\
\hline & $\mathrm{n}$ & Median Wr & $\mathrm{n}$ & Median Wr \\
\hline Agency Near-Shore & 1 & 118 & 4 & 107 \\
\hline Agency Off-Shore & 4 & 94 & 13 & 98 \\
\hline Goose Bay & 4 & 102 & 17 & 103 \\
\hline Tulana Emergent & 1 & 132 & 0 & - \\
\hline Tulana Submergent & 8 & 106 & 30 & 102 \\
\hline Tulana Open Water & 8 & 98 & 26 & 100 \\
\hline
\end{tabular}




\section{Acknowledgments}

We thank Jared Bottcher, Megan Dethloff, Terra Kemper, James Latshaw, Randal Lodges, Debra Warenbrock, Anna Willard, and Jolene Willis for help with data collection. We also thank Greta Blackwood, Alta Scott and Amari Dolan-Caret for help with database development and management. Craig Ellsworth (Klamath Falls Field Station), Heather Hendrixson (TNC), David Hewitt (Klamath Falls Field Station), Douglas Markle (Oregon State University), Tamara Wood (Oregon Water Science Center), and Scott VanderKooi (Klamath Falls Field Station) helped with study design. Tamara Wood and Kristopher Kannarr helped with interpretation of water quality data. We also thank TNC for giving us access to the land that much of this study was conducted on and providing us with bathymetry and vegetation map data cited in this report. This work was funded by the Bureau of Reclamation (Interagency Agreement 04AA204032) and the U.S. Geological Survey. 
Publishing support provided by the U.S. Geological Survey

Publishing Network, Tacoma Publishing Service Center

For more information concerning the research in this report, contact the Director, Western Fisheries Research Center U.S. Geological Survey, 6505 NE 65th Street Seattle, Washington 98115

http://wfrc.usgs.gov/ 
